MÁRCIA CRISTINA NOGUEIRA CIAMPAGLIA

\title{
ATO ADMINISTRATIVO INVÁLIDO E A RESTAURAÇÃO DA LEGALIDADE
}

Dissertação de Mestrado

Orientador: Prof. Dr. Edmir Netto de Araújo

FACULDADE DE DIREITO DA USP

SÃO PAULO

2014 


\title{
ATO ADMINISTRATIVO INVÁLIDO E A RESTAURAÇÃO DA LEGALIDADE
}

\author{
Dissertação apresentada como \\ requisito parcial para obtenção do título \\ de Mestre em Direito, do Programa de \\ Pós-Graduação Stricto Sensu em Direito \\ do Estado, da Faculdade de Direito da \\ Universidade de São Paulo. \\ Orientador: Professor Doutor Edmir \\ Netto de Araújo
}




\section{ATO ADMINISTRATIVO INVÁLIDO E A RESTAURAÇÃO DA LEGALIDADE}

Dissertação aprovada como requisito parcial para obtenção do título de Mestre em Direito, do Programa de Pós-Graduação Stricto Sensu em Direito do Estado, da Faculdade de Direito da Universidade de São Paulo pela seguinte banca examinadora:

Orientador:

Prof. Dr. Edmir Netto de Araújo

Faculdade de Direito - USP

Membros:

Prof. Dr.

Prof. Dr.

Data de Aprovação: 


\section{AGRADECIMENTOS}

Ao meu orientador, Prof. Dr. Edmir Netto de Araújo, que apesar de ter atingido o ápice do reconhecimento social e profissional, rechaçou a vaidade e conservou a grandeza dos gestos simples. Agradeço por ter sido um modelo de conduta e por ter ampliado os meus conhecimentos científicos na área do Direito.

Ao Prof. Dr. Fernando Dias Menezes de Almeida e Prof. Dr. Roger Stiefelmann Leal pelas valiosas sugestões na banca de qualificação.

Ao meu pai, Márcio Franklin Nogueira, pelo incansável incentivo ao longo da trajetória acadêmica e a minha mãe, Eloisa Bragotto Nogueira, por me dar suporte no cotidiano familiar, nos momentos que exigiu de mim, maior dedicação ao trabalho.

Ao meu marido, Mauricio Ciampaglia pelo companheirismo e apoio constante, e as minhas filhas Mariana e Gabriela pela paciência e compreensão diante dos momentos em que me ausentei. 


\section{RESUMO}

O objetivo da presente dissertação é demonstrar quais são as formas em que a legalidade pode ser restaurada, diante de um ato administrativo inválido, bem como quais os critérios e interesses a serem considerados na opção por uma destas formas. Para tanto, iniciamos pelo estudo do ato administrativo, seus elementos e requisitos de validade. Em seguida, passamos ao estudo do ato administrativo inválido e os diferentes graus de invalidade dependendo do elemento do ato atingido pelo vício. Na sequencia, analisamos os dois princípios que são fundamentais para nortear o administrador na escolha do melhor meio de restaurar a legalidade: o princípio da legalidade e o da segurança jurídica. A partir daí, elencamos as formas de restauração da legalidade por meio da manutenção dos efeitos do ato administrativo inválido (convalidação e suas espécies) e da retirada do ato e extinção dos seus efeitos (revogação e anulação). Ainda sob a ótica da restauração de legalidade, analisamos os institutos da prescrição e decadência, uma vez que estes constituem limites à invalidação. Por fim, demonstramos a imprescindibilidade da instauração do processo administrativo para restauração da legalidade, que em tese pode lesar direitos e interesses de terceiros.

Palavras-chave: ato administrativo - legalidade - segurança jurídica - anulação convalidação - revogação - prescrição - decadência. 


\begin{abstract}
The objective of this dissertation is to demonstrate what are the ways in which legality can be restored before an invalid administrative act, as well as the criteria and interests to be considered in the choice of one of these forms. To this end, we initiated the study of the administrative act, its elements and requirements of validity. Then we move to the study of invalid administrative act and the different degrees depending on the element of invalidity of the act reached by addiction. In the sequel, we analyze the two fundamental principles that are to guide the administrator to choose the best way to restore legality: the principle of legality and legal certainty. From there, we list the forms of restoration of legality by the maintenance of the effects of invalid administrative act (convalidation and its species) and the withdrawal of the act and termination of its effects (revocation and annulment). Yet from the perspective of restoring legality, we analyze the institutes of prescription and decadence, since these are limits to invalidation. Finally, we demonstrate the indispensability of initiation of the administrative procedure for restoration of legality, which in theory would harm the rights and interests of third parties.
\end{abstract}

Keywords: administrative act - legal - legal certainty - annulment - convalidation revocation - prescription - decadence. 


\section{SUMÁRIO}

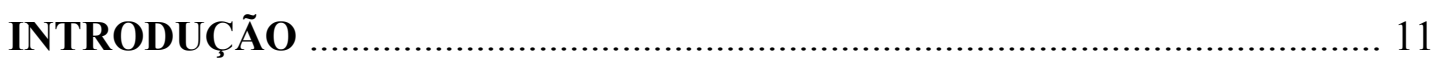

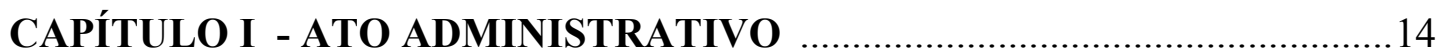

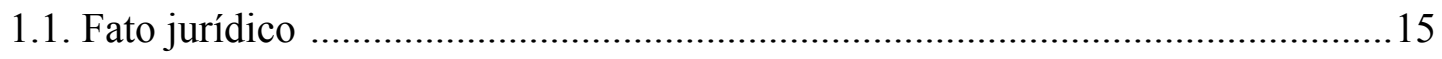

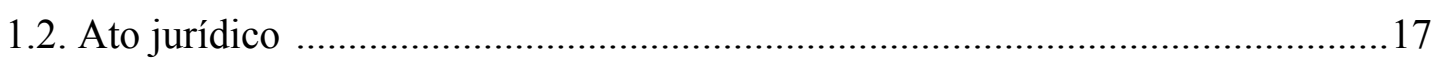

1.3. Atos da Administração Pública ............................................................................ 19

1.4. Conceito de ato administrativo …………………………………………........ 19

1.5. Elementos e requisitos do ato administrativo ………………………………... 22

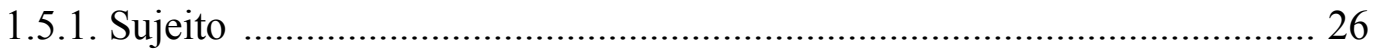

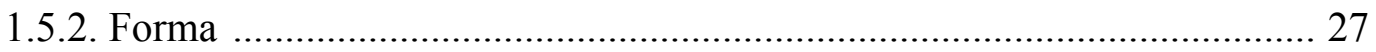

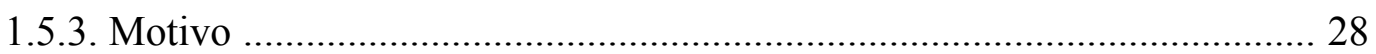

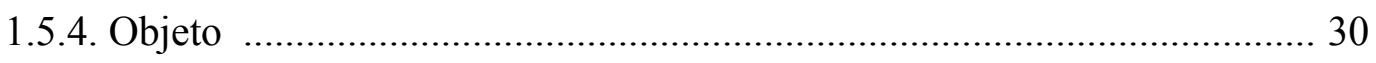

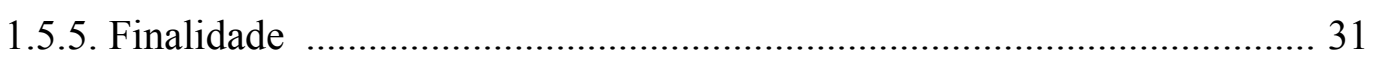

1.6. Atributos do ato administrativo ................................................................... 32

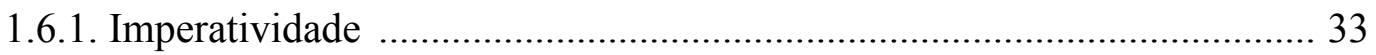

1.6.2. Presunção de legitimidade …………………………………………..... 33

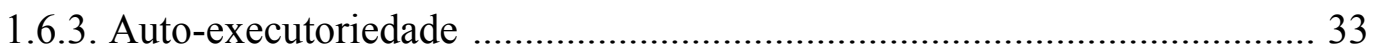

CAPÍTULO II - ATO ADMINISTRATIVO INVÁLIDO …………………….... 34

2.1. Vícios relativos ao sujeito ............................................................................ 34

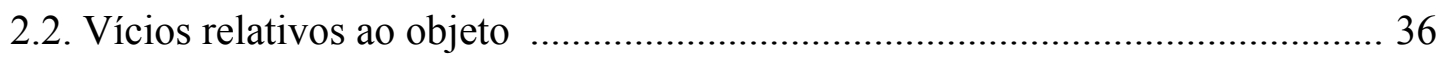

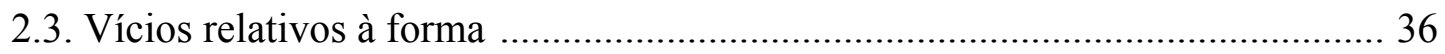

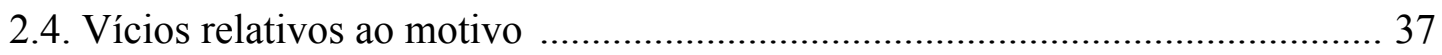

2.5. Vícios relativos à finalidade ………………………………………………. 37

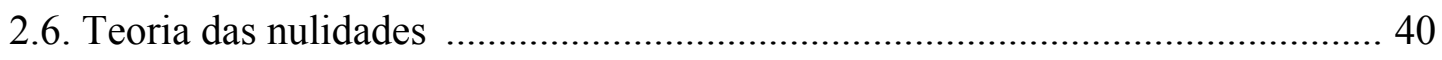

2.6.1.Transposição da teoria das nulidades do Direito Civil para o Direito

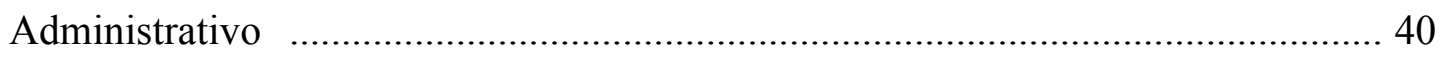

2.6.2. Posição de Hely Lopes Meirelles ……………………………………….. 43

2.6.3. Posição de Oswaldo Aranha Bandeira de Mello .......................................... 44

2.6.4. Posição de Rui Cirne Lima ..................................................................... 44

2.6.5. Posição de Miguel Seabra Fagundes …………………………………... 45

2.6.6. Posição de Celso Antônio Bandeira de Mello ............................................ 45 
2.7. Atos inexistentes, nulos, anuláveis, irregulares 45

2.8. Critérios de classificação dos atos administrativos inválidos ........................... 48

2.8.1. Critério utilizado pela Lei da Ação Popular ............................................ 49

2.8.2. Critério da possibilidade de convalidação .............................................. 49

2.8.3. Critério da legitimidade para provocar a invalidação ................................50

2.8.4. Critério da possibilidade de anulação de ofício .........................................52

2.8.5. Critério da incidência de prazo prescricional para anulação .................... 53

\section{CAPÍTULO III - PRINCIPIO DA LEGALIDADE NA ADMINISTRAÇÃO}

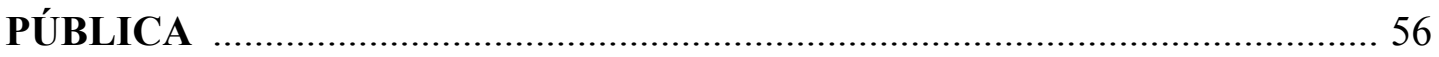

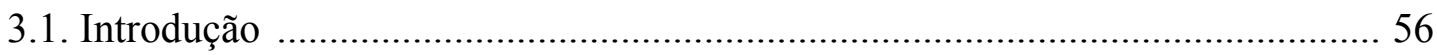

3.2. Evolução da concepção de Estado .................................................................... 56

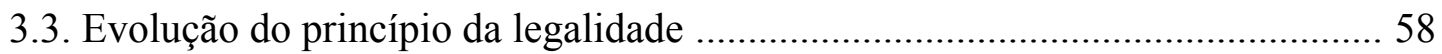

3.4. Consequências da atual concepção do princípio da legalidade ......................... 62

\section{CAPÍTULO IV - PRINCIPIO DA SEGURANÇA JURÍDICA NA}

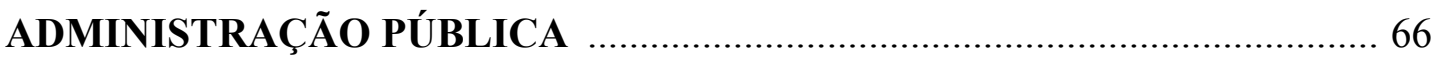

4.1. Da aplicação dos princípios da segurança jurídica, proteção à confiança e boafé na Administração Pública

\section{CAPÍTULO VI - RETIRADA DO MUNDO JURÍDICO DO ATO} ADMINISTRATIVO INVÁLIDO: revogação, anulação ou invalidação ............. 81

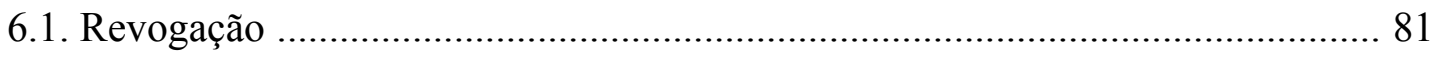

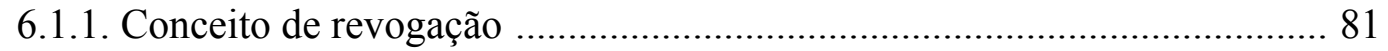

6.1.2. Espécies de revogação .......................................................................... 81

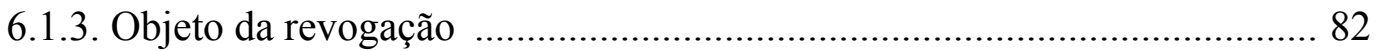

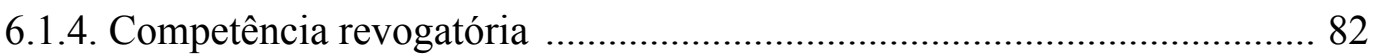

6.1.5. Natureza jurídica e efeitos da revogação .................................................. 83

6.1.6. Motivo da revogação ........................................................................ 83

6.1.7 Limites ao poder de revogação dos atos administrativos ......................... 86

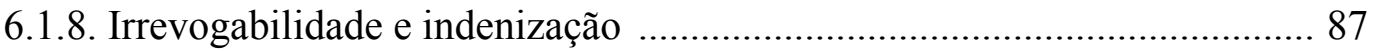

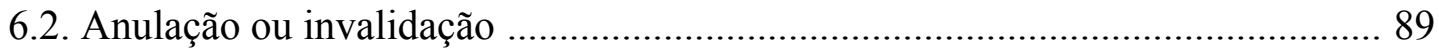




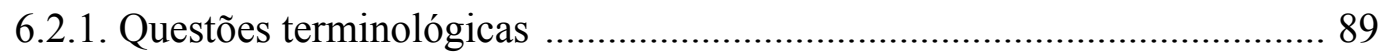

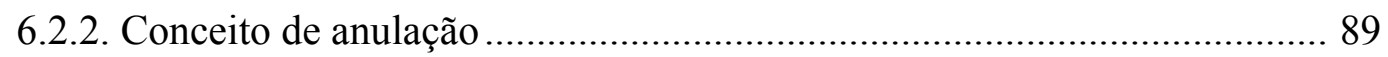

6.2.3. Competência para anulação ................................................................. 90

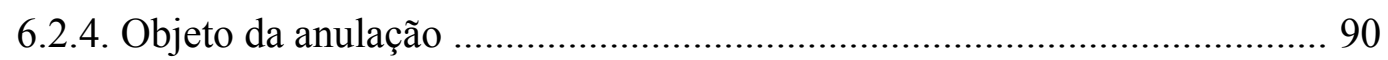

6.2.5. Natureza jurídica e efeitos da anulação ................................................... 90

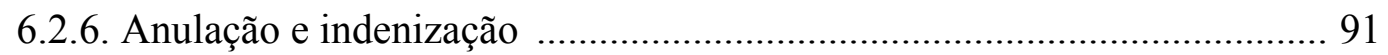

6.2.7. Direito de resistência contra atos inválidos .............................................. 91

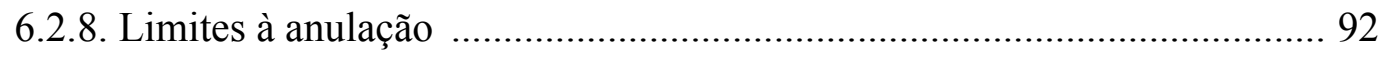

\section{CAPÍtULO VII - MANUTENÇÃO DOS EFEITOS DO ATO} ADMINISTRATIVO INVÁLIDO: A CONVALIDAÇÃ̃ .............................. 94

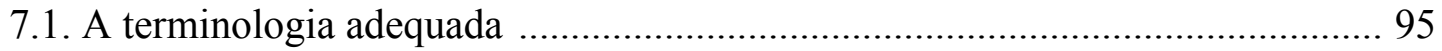

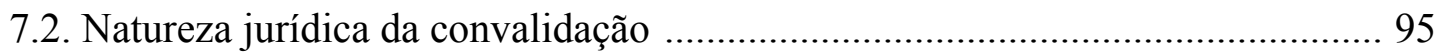

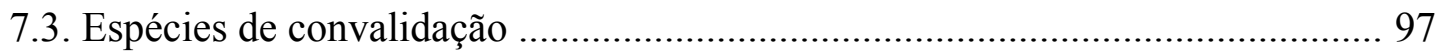

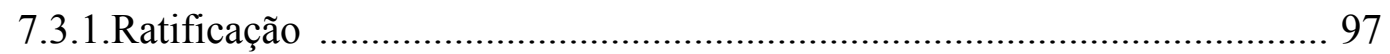

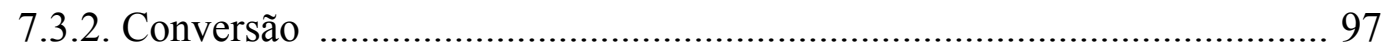

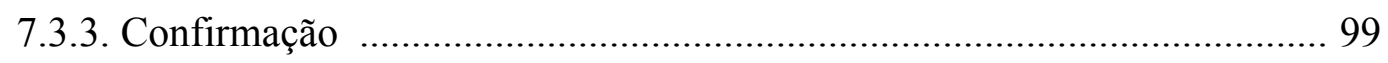

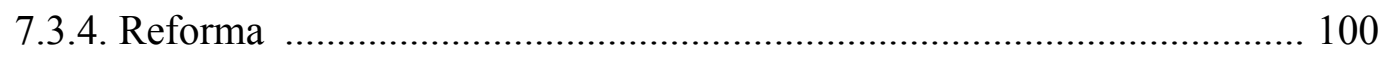

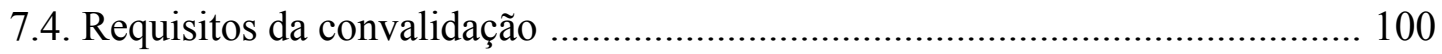

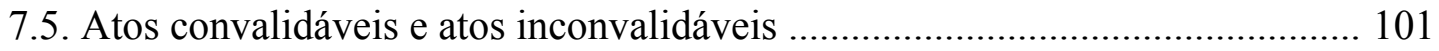

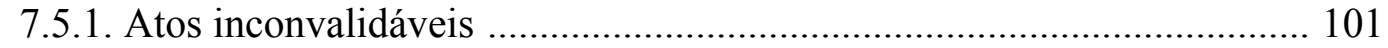

7.5.1.1. Com vício de finalidade ................................................................ 102

7.5.1.2. Com vício de motivo ................................................................. 103

7.5.1.3. Com vício de conteúdo ou objeto .............................................. 104

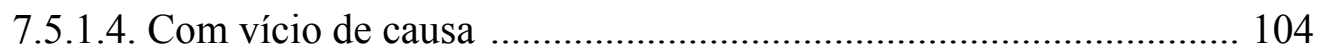

7.5.1.5.Com vício de formalidade e de procedimento ............................... 105

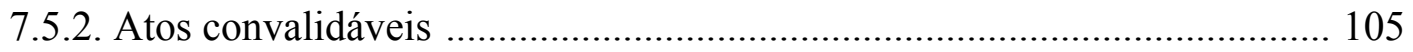

7.5.2.1.Com vício de competência ........................................................... 106

7.5.2.3. Com vício de formalidade ........................................................... 106

7.5.2.4. Com vício de procedimento ......................................................... 106

7.6. Limites a convalidação ............................................................................... 107

7.7. Obrigatoriedade ou faculdade de convalidação ............................................. 111 
8.1. Limite temporal a autotutela da Administração Pública

8.1.1. Decadência do poder de recompor a legalidade: regra ou exceção?

8.1.2. Prazos decadenciais

8.1.3. Exceções à incidência de prazo decadencial sobre o poder de rever os atos administrativos ilegais

8.2. Prescrição da pretensão de pleitear judicialmente a anulação do ato administrativo inválido

8.2.1. Exceção a regra de prescrição de pleitear anulação do ato administrativo inválido

8.3. A prescrição e decadência do poder de anular os atos administrativos ilegais como forma de restauração da legalidade

\section{CAPÍTULO IX - O DEVIDO PROCESSO LEGAL NA REVISÃO DOS}

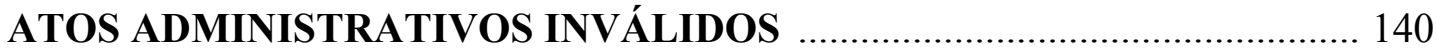

9.1. Questões terminológicas: processo ou procedimento administrativo .............. 141

9.2. Princípios informadores do processo administrativo .......................................143

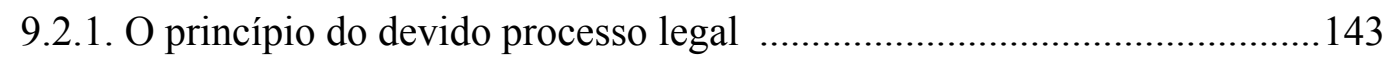

9.2.2. O princípio do contraditório . .............................................................. 148

9.2.3. O princípio da ampla defesa .............................................................. 147

9.2.4. O princípio da razoável duração do processo .......................................... 149

9.2.5. O princípio da oficialidade ................................................................. 150

9.2.6. O principio da verdade material ........................................................ 150

9.2.7. O princípio do formalismo moderado ................................................. 150

9.3. Finalidades do processo administrativo .................................................... 151

9.4. Fases do processo administrativo .............................................................. 153

9.4.1. Fase de instauração ............................................................................ 154

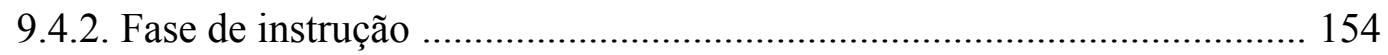

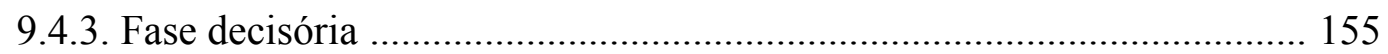

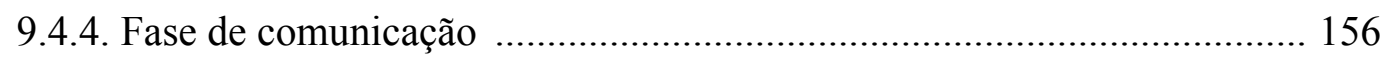

9.5. Necessidade de motivação ...................................................................... 156

9.6. Importância do processo administrativo na revisão dos atos administrativos

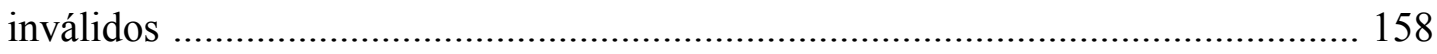




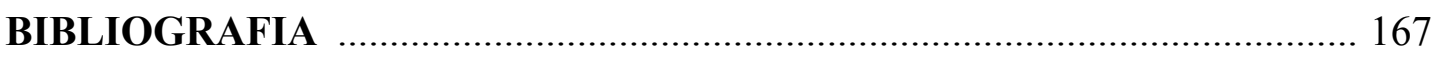




\section{INTRODUÇÃO}

O Estado Democrático de Direito fundamenta-se na supremacia da Constituição, na incidência do princípio da legalidade, na universalidade da jurisdição, na supremacia da soberania popular e principalmente no respeito aos direitos fundamentais.

Assim, o Estado tem como finalidade precípua a realização da dignidade dos indivíduos. Tal objetivo é alcançado através das diversas funções estatais: legislativa, judiciária e administrativa.

De acordo com o princípio da separação dos poderes, à Administração Pública compete o exercício da função administrativa.

A função administrativa é um conjunto de competências instituídas pelo ordenamento jurídico com a finalidade de promover a satisfação de interesses relacionados aos direitos fundamentais.

A materialização do exercício desta função administrativa ocorre através da prática de atos administrativos. Por isso, a importância de estudá-los. A compreensão de seus elementos, suas características, e suas diversas formas de extinção nos permite a assimilação de todos os institutos de Direito Administrativo, através dos quais a Administração Pública concretiza o atendimento aos interesses coletivos.

Inserido no campo do controle dos atos administrativos, tem-se a invalidação consistente na sua extinção por motivo de ilegalidade com efeitos retroativos a data de sua edição, como conseqüência da submissão da Administração Pública ao princípio da legalidade.

Esta forma de extinção, fundamentada unicamente no princípio da legalidade, determina que na hipótese do ato administrativo violar um dispositivo legal, a única solução possível será sua anulação e de seus efeitos, independentemente das conseqüências futuras de seu desfazimento.

No entanto, o principio da legalidade, a que se submete a Administração Pública deve ser visto em seu sentido amplo, ou seja, a atuação administrativa deve se submeter não somente à lei em sentido estrito, mas a todo ordenamento jurídico. Desta forma, será demonstrado neste trabalho que a extinção do ato administrativo ilegal, não é a única forma de restabelecimento da legalidade. 
Na busca do interesse público, consistente na preservação da dignidade dos indivíduos, a Administração Pública ao decidir se extingue ou não um dado ato administrativo viciado deverá considerar os efeitos por ele já produzidos. Muitas vezes, a solução mais adequada à satisfação do interesse público será a manutenção do ato ou a preservação de seus efeitos, pois muitas vezes tais atos já constituíram relações jurídicas, envolvendo terceiros estranhos à Administração Pública.

Assim, não se pode dizer que a retirada do ato administrativo viciado é o único meio de garantir a observância do princípio da legalidade. A sua manutenção, ou de seus efeitos também é uma forma de resgatar a legalidade preservando as relações jurídicas e as situações fáticas decorrentes do ato viciado.

O tema a ser desenvolvido pretende investigar o ato administrativo inválido e as formas de restauração da legalidade: revogação, anulação, convalidação e prescrição administrativa e judicial para revisão dos atos administrativos.

Para tanto, abordaremos, preliminarmente, o conceito de ato administrativo, seus elementos ou requisitos, bem como seus atributos.

Concluído o estudo sobre o ato administrativo de forma geral, passar-se-á à análise do ato administrativo inválido, com início pelo estudo da teoria das nulidades, e o posicionamento dos diversos autores quanto à possibilidade de transposição desta teoria originária do Direito Civil para o Direito Administrativo. Também serão estudadas as espécies de vícios em cada um dos elementos do ato administrativo, suas consequências e as diversas formas de classificação das invalidades, com ênfase naquelas os distingue em atos administrativos inexistentes, nulos, anuláveis e irregulares.

Em seguida, abordaremos os princípios da legalidade e da segurança jurídica, importantes elementos a serem considerados pelo administrador ao decidir se retira ou mantém no mundo jurídico determinado ato administrativo inválido.

Analisaremos as formas de restauração da legalidade, procurando-se demonstrar - em que pese o posicionamento de alguns doutrinadores que entendem ser a invalidação a única forma de restauração da legalidade - que a opção pela invalidação ou convalidação depende da ponderação, diante do caso concreto, dos princípios constitucionais, determinando-se qual deverá prevalecer: legalidade em sentido estrito ou segurança jurídica. 
Igualmente importante, ao se tratar das formas de restauração da legalidade são as questões referente ao prazo para revisão do ato administrativo ilegal - que será tratado no capítulo sobre prescrição e decadência - e a necessidade de instauração de processo administrativo prévio, com as garantias do contraditório e ampla defesa, contidos no capítulo sobre devido processo legal na revisão dos atos administrativos inválidos. 


\section{ATO ADMINISTRATIVO}

\subsection{Fato jurídico}

Como se sabe, o ato administrativo é espécie de ato jurídico; este, por sua vez, é espécie de fato jurídico. Por isso, o estudo do ato administrativo passa, necessariamente, pelo exame do fato jurídico.

Dos fatos que ocorrem no mundo real nem todos têm importância para o Direito. Apenas importam ao Direito aqueles fatos aos quais uma norma jurídica atribui uma qualificação, um significado ou uma consequência jurídica.

Os fenômenos naturais em si, tais como a chuva, o crescimento da vegetação, o eclipse solar, nada significam para o Direito, a menos que este lhes atribua alguma consequência. É o que ocorre, exemplificativamente, com a "moratória, em hipótese de violentas chuvas que tenham dizimado a produção agrícola" ${ }^{1}$.

Estes fatos, aos quais o Direito atribui consequências jurídicas, são fatos jurídicos. Dai a lição de Edmir Netto de Araújo²: “É, portanto, a incidência de certa norma jurídica sobre um fato que lhe atribui a natureza de fato jurídico”.

Assim, "o fato jurídico compreende os acontecimentos que ao realizar-se devem produzir a consequência de direito" ${ }^{3}$.

Alguns fatos jurídicos independem da ação humana. São os fatos objetivos $^{4}$ ou involuntários ${ }^{5}$. Cite-se como exemplo "o tempo, ao qual o direito empresta a significação jurídica de extinção ou criação de direitos, tal como a prescrição, a decadência" ", ou então o incêndio de causas desconhecidas, quando coberto por um contrato de seguro ${ }^{7}$.

Contrapondo-se aos fatos jurídicos objetivos ou involuntários estão os fatos humanos ${ }^{8}$ ou voluntários ${ }^{9}$. Estes compreendem, “as ações humanas, praticadas

\footnotetext{
${ }^{1}$ OLIVEIRA, Regis Fernandes de. Ato administrativo. 5. ed. São Paulo: Revista dos Tribunais, 2007, p. 53

${ }^{2}$ ARAÚJO. Edmir Netto de. Curso de Direito Administrativo. 6. ed. São Paulo: Saraiva, 2014, p. 486

${ }^{3}$ DROMI, José Roberto. Instituciones de Derecho Administrativo. Buenos Aires: Editorial Astrea de R. Depalma, 1973, p. 178

${ }^{4}$ OLIVEIRA, Regis Fernandes de. Op. cit., p. 53

${ }^{5}$ ARAÚJO. Edmir Netto de. Op. cit., p. 486

${ }^{6}$ OLIVEIRA, Regis Fernandes de, Op.cit., p. 53-54

${ }^{7}$ ARAÚJO. Edmir Netto de. Op. cit., p. 486

${ }^{8}$ OLIVEIRA, Regis Fernandes de. Op. cit., p.54
} 
deliberadamente para a obtenção de certos efeitos jurídicos, que podem ser desejados pelo sujeito da ação, ou assumidos por quem a pratica. Ou, ainda, praticadas deliberadamente (sob o aspecto físico), mas sem que o sujeito deseje ou assuma essas consequências jurídicas, as quais, mesmo contra sua vontade, se produzem"10.

O fato jurídico humano é, portanto, uma ação humana, material ou técnica, que produz certo efeito jurídico, independentemente de ser este desejado pelo sujeito que o pratica. É exemplo de fato jurídico humano "a demolição de um edifício pela autoridade administrativa, por razões de segurança, sem a decisão prévia do órgão competente" $" 11$.

\subsection{Ato jurídico}

Os atos jurídicos, espécie de fatos jurídicos, "são declarações de vontade, conhecimento ou opinião, destinadas a produzir efeitos jurídicos, ou seja, o nascimento, modificação ou extinção de direitos e obrigações" ${ }^{12}$.

Assim, o fato jurídico humano, quando decorrente de uma declaração de vontade, é ato jurídico.

A declaração de vontade é elemento essencial do ato jurídico.

Régis Fernandes de Oliveira ${ }^{13}$, acompanhando Agustin A. Gordillo, afirma que a declaração de vontade engloba "todos os atos, não apenas os de mera manifestação da vontade, mas também os que emitem conhecimento, juízo ou opinião”. Percebe-se que para este doutrinador, a declaração de vontade é gênero, do qual a manifestação da vontade é uma espécie.

De acordo com Edmir Netto de Araújo ${ }^{14}$, ato jurídico é a vontade exteriorizada e projetada no mundo jurídico. A vontade pode se exteriorizar por meio de uma manifestação ou declaração. No entanto, para que se projete no mundo jurídico é necessário que a manifestação desta vontade ocorra de maneira formal, conforme prescrito pelo ordenamento jurídico, significando que a pessoa deseja ou assume as consequências

\footnotetext{
${ }^{9}$ ARAÚJO. Edmir Netto de, Op. cit., p. 486

${ }^{10}$ Idem, ibidem, p.486

${ }^{11}$ DROMI, José Roberto. Instituciones de Derecho Administrativo, cit., p. 177

12 Idem, ibidem, p. 177

${ }^{13}$ OLIVEIRA, Regis Fernandes de. Op cit., p. 54

${ }^{14}$ ARAÚJO. Edmir Netto de, Op. cit., p. 486
} 
desta manifestação. Assim, para que produza os efeitos jurídicos a manifestação de vontade deve se converter em declaração de vontade.

Para este doutrinador a "manifestação de vontade, portanto, é gênero (pois abrange inclusive o silêncio ou omissão), do qual declaração de vontade é espécie"15.

Maria Sylvia Zanella di Pietro ${ }^{16}$ também prefere utilizar a expressão "declaração" porque esta compreende exteriorização do pensamento, uma vez que a "manifestação" pode não ser exteriorizada, como no caso do silêncio que é capaz de representar manifestação volitiva e produzir efeito jurídico, sem que corresponda a um ato jurídico típico.

No mesmo sentido, Renato Alessi, ao tratar da teoria do acordo administrativo, explica que

a manifestação implica a ideia de uma atividade, ou com maior generalidade ainda (tendo em conta as chamadas atividades negativas: omissões, denegações, silêncio), um comportamento, de maneira que devemos deixar compreendidas não somente aquelas que são propriamente declarações (de uma vontade de provocar modificações jurídicas) ${ }^{17}$.

E prossegue afirmando que a manifestação compreende

as expressões formalmente autônomas de determinações volitivas (mero acordos formais) relativas a posterior realização de uma atividade jurídica ou material; as declarações de vontade administrativa de provocar qualquer modificação jurídica através da qual se realize um interesse público concreto (ordens, proibições, expropriações, concessões, autorizações, etc); as outras declarações que tem conteúdo distinto e que produzem imediatamente modificações jurídicas adequadas para a realização de um interesse público concreto (registros, inscrições, etc.); também, excepcionalmente, o comportamento material de um órgão

\footnotetext{
${ }^{15}$ Idem, ibidem, p. 487

${ }^{16}$ DI PIETRO, Maria Sylvia Zanella. Direito Administrativo. 24. ed. São Paulo: Atlas, 2011, p. 195

${ }^{17}$ ALESSI, Renato. Instituiciones de Derecho Administrativo. Trad. Buenaventura Pellisé Prats. Tomo I. Barcelona: Bosh, 1970, p. 255
} 
administrativo que, sem embargo, seja - e precisamente é - produtor de modificações jurídicas e exercício de um poder ${ }^{18}$.

Mas, independente da denominação utilizada - manifestação ou declaração de vontade - o que deve ser ressaltado é que no ato jurídico há sempre uma vontade, explícita ou implicitamente manifestada de alcançar a consequência prevista pela norma.

\subsection{Atos da Administração Pública}

A Administração Pública, no exercício de suas atividades e para o atingimento de seus fins, pratica uma série de atos, que num sentido amplo denominam-se Atos da Administração Pública ${ }^{19}$. Portanto, nem todos os atos praticados pela Administração Pública são atos administrativos.

Estes atos podem ou não ter consequências jurídicas. Os que não se destinam a produzir efeitos jurídicos, denominam-se atos materiais, fatos administrativos, ou ainda, atos de administração. São atos "dirigidos à realização, em concreto, da atividade administrativa, em seus aspectos técnicos ou operacionais" ${ }^{20}$. Pode-se citar como exemplo o ato de ministrar aulas, de operar um paciente, de pavimentar uma rua ${ }^{21}$.

Os atos, praticados pela Administração Pública, ao qual o ordenamento jurídico atribui consequências denominam-se atos jurídicos da Administração Pública.

Estes quando regulados pelo Direito Civil são chamados de atos jurídicos (privados) da Administração. Quando há a incidência de normas de direito público, com o Estado em posição de supremacia, configuram o ato administrativo.

\subsection{Conceito de ato administrativo}

Vários critérios têm sido utilizados para definir o ato administrativo. Dentre eles, os de maior relevância são os critérios objetivo e subjetivo.

\footnotetext{
${ }^{18}$ Idem, ibidem, p. 255

${ }^{19}$ GASPARINI, Diógenes. Direito Administrativo. 14. ed, São Paulo: Saraiva, 2009, p. 57

${ }^{20}$ ARAÚJO. Edmir Netto de. Op. cit., p. 496

${ }^{21}$ MELLO, Celso Antonio Bandeira. Curso de Direito Administrativo. 17. ed. São Paulo: Malheiros, 2004, p. 351
} 
Utilizando-se o critério subjetivo, orgânico ou formal, leva-se em conta o sujeito que pratica o ato. Assim, considera-se ato administrativo todo aquele editado por órgãos administrativos.

No entanto, sabe-se que a função administrativa não é exercida com exclusividade pela Administração Pública. Embora haja uma distribuição de funções entre os três Poderes, esta não é rígida, de forma que cada qual desempenha sua função típica e paralelamente pode exercer algumas das atribuições dos outros poderes. Assim, os Poderes Legislativo e Judiciário, além de possuírem na sua estrutura órgãos administrativos - que compõem a chamada Administração Pública - exercem função tipicamente administrativa, editando, portanto, atos administrativos no que se referem ao funcionamento interno de seus órgãos e seus agentes ${ }^{22}$.

Portanto, a deficiência do critério subjetivo reside no fato de excluir os atos praticados pelos órgãos legislativos e judiciários no exercício de função administrativa e abarcar todos os atos praticados pela Administração Pública, inclusive os atos materiais e os atos jurídicos privados ${ }^{23}$.

Pelo critério objetivo, material ou funcional, é ato administrativo somente aquele praticado no exercício concreto da função administrativa, independentemente do órgão que o profere. Assim, incluem-se os atos praticados pelos três Poderes estatais quando exercentes de função administrativa e excluem-se os atos normativos do Poder Executivo, tal como os regulamentos, por terem um caráter genérico $^{24}$.

No entanto, este critério ainda é insuficiente para caracterizar o ato administrativo, uma vez que permite incluir os atos praticados no exercício da função administrativa sob regime de Direito Privado ${ }^{25}$.

A fim de solucionar esta questão, permitindo uma identificação precisa do ato administrativo, os doutrinadores buscaram associar ao critério objetivo novos elementos. Para alguns, o ato administrativo caracteriza-se pela presença da potestade pública, ou seja, é ato administrativo quando praticado pela Administração Pública no uso de suas prerrogativas. Para outros, é o regime jurídico administrativo que o caracteriza ou,

\footnotetext{
${ }^{22}$ DI PIETRO, Maria Sylvia Zanella. Op. cit., p. 193

${ }^{23}$ Idem, ibidem, p. 196

${ }^{24}$ Idem, ibidem, p. 196

${ }^{25}$ Idem, ibidem, p. 196
} 
ainda, há aqueles que só consideram atos administrativos os que contêm uma declaração de vontade que produz efeitos jurídicos.

Edmir Netto de Araújo $^{26}$, considerando ser o ato administrativo uma espécie de ato jurídico define-o como

a declaração de vontade do Estado, nesta qualidade, exteriorizada por agente competente e no exercício de suas funções, visando a produção de efeitos jurídicos conformes ao interesse público, com ela objetivados, determinados ou admitidos pelo ordenamento jurídico, em matéria administrativa.

Celso Antônio Bandeira de Mello conceitua ato administrativo em duas acepções: ampla e restrita.

Em sentido amplo, abrangendo os atos abstratos, como o regulamento, ato administrativo é

declaração do Estado (ou de quem lhe faça as vezes - como, por exemplo, um concessionário de serviço público), no exercício de prerrogativas públicas, manifestada mediante providências jurídicas complementares da lei a título de lhe dar cumprimento, e sujeita a controle de legitimidade por órgão jurisdicional ${ }^{27}$.

Em sentido estrito, acresce ao conceito concreção e unilateralidade. Assim, ato administrativo em sentido estrito é uma

“declaração unilateral do Estado no exercício de prerrogativas públicas, manifestada mediante comandos concretos complementares da lei (ou, excepcionalmente, da própria Constituição, aí de modo plenamente

\footnotetext{
${ }^{26}$ ARAÚJO. Edmir Netto de. Op cit., p. 498

${ }^{27}$ MELLO, Celso Antonio Bandeira. Op. cit. p. 352
} 
vinculado) expedidos a título de lhe dar cumprimento e sujeitos a controle de legitimidade por órgão jurisdicional" ${ }^{28}$.

Para Régis Fernandes de Oliveira ${ }^{29}$, ato administrativo é “declaração unilateral do Estado, ou de quem faça suas vezes, no exercício da função administrativa, que produza efeitos jurídicos”.

Maria Sylvia Zanella di Pietro ${ }^{30}$ define ato administrativo como "a declaração do Estado ou de quem o represente que produz efeitos jurídicos imediatos, com observância da lei, sob regime jurídico de direito público e sujeita a controle pelo Poder Judiciário".

Para José dos Santos Carvalho Filho ${ }^{31}$ ato administrativo é a “exteriorização da vontade de agentes da Administração Pública ou de seus delegatários, nessa condição, que, sob regime de direito público, vise à produção de efeitos jurídicos, com o fim de atender ao interesse público".

De forma sucinta, João Antunes dos Santos $\mathrm{Neto}^{32}$, partindo dos conceitos formulados pelos doutrinadores administrativistas, conclui que o ato administrativo consiste em "declaração estatal feita sob regime jurídico de direito público, derrogatório e exorbitante do direito comum, formulado para consolidar o interesse coletivo e a busca pelo bem comum".

Diversas, como se vê, as definições de ato administrativo. Delas, no entanto, é possível identificar características essenciais que permitem diferenciá-lo dos demais atos jurídicos.

É uma declaração de vontade do Estado, efetuada no exercício de suas prerrogativas, ou seja, se sujeita ao regime jurídico administrativo, que produz efeitos jurídicos imediatos, cujo objetivo é atender ao interesse público e sindicável pelo Poder Judiciário.

\footnotetext{
${ }^{28}$ Idem, ibidem, p. 354

${ }^{29}$ OLIVEIRA, Régis Fernandes de. Ato administrativo. $5^{\text {a }}$ ed. São Paulo: Revista dos Tribunais, 2007, p. 70

${ }^{30}$ DI PIETRO, Maria Sylvia Zanella. Op. cit., p. 198

${ }^{31}$ CARVALHO FILHO, José dos Santos. Manual de Direito Administrativo. 12. ed. Rio de Janeiro: Lumen Juris, 2004, p.89

32 SANTOS NETO, João Antunes dos. Op. cit., p. 99
} 


\subsection{Elementos e requisitos do ato administrativo}

O processo de formação do ato administrativo tem início com a ocorrência de uma circunstância fática ou de direito (motivo) e que provoca o impulso volitivo da Administração Pública de emitir uma declaração, por meio de um agente competente (agente), que assume uma determinada forma prescrita ou permitida pelo ordenamento jurídico (forma ou formalidade) e tem como objetivo imediato produzir determinado efeito jurídico (objeto) para alcançar um resultado de interesse público (finalidade) $)^{33}$.

Assim, para que o ato se considere completo é necessário que reúna todos estes elementos ou requisitos.

Em relação à terminologia adotada (elementos, requisitos) os doutrinadores divergem. Alguns consideram como elementos o que outros o fazem como requisitos, ou ainda, há aqueles que as utilizam como expressões sinônimas.

Para Edmir Netto de Araújo ${ }^{34}$ elementos e requisitos dos atos administrativos são expressões distintas, com significações diversas. Os elementos são necessários para existência do ato, os requisitos são condicionantes de sua validade.

Quanto aos elementos, subdivide-os em intrínsecos, contidos dentro do próprio ato, e extrínsecos, fora do ato. Os elementos intrínsecos são a declaração de vontade, a forma e o objeto (ou conteúdo). Os elementos extrínsecos são o agente que manifesta a vontade do Estado e o binômio tempo/lugar, sem o qual nem mesmo haveria fato jurídico ${ }^{35}$.

Os requisitos do ato administrativo são os mesmos dos atos jurídicos em geral - capacidade e competência, declaração válida de vontade, objeto lícito, possível e forma legalmente prescrita ou não vedada - acrescidos do motivo, e finalidade ${ }^{36}$.

Desta forma, para que o ato administrativo exista são necessários um agente público que emita uma declaração de vontade do Estado de determinada forma incidente sobre uma relação jurídica (conteúdo ou objeto) em dado lugar e em certa época. E para que seja válido é preciso que o agente seja capaz e competente, sua declaração de vontade seja válida, o objeto seja lícito, possível e conforme ao interesse público

\footnotetext{
${ }^{33}$ ARAÚJO, Edmir Netto de. Curso de Direito Administrativo, cit., p. 501

${ }^{34}$ Idem, ibidem, p. 498

${ }^{35}$ Idem, ibidem, p. 498

${ }^{36}$ Idem, ibidem, p. 499
} 
concretamente existente, a forma legalmente prescrita ou não vedada, o motivo existente e de acordo com interesse público, e a finalidade correspondente a este motivo.

Relativamente à declaração de vontade, como elemento intrínseco do ato administrativo, Edmir Netto de Araújo $^{37}$ afirma ser "a ação ou abstenção humanas (atos comissivos e omissivos) que tomam alguma forma (escrita, oral, mímica, gestos, silêncio, inação, omissão, etc.)". De acordo com esta afirmação é possível concluir que tanto a omissão como o silêncio podem ser elementos do ato administrativo. A omissão como espécie de declaração de vontade, e o silêncio como espécie de forma.

Di Pietro ${ }^{38}$ considera o silêncio como manifestação de vontade - gênero do qual a declaração é espécie - e embora possa produzir efeito jurídico, quando a lei assim determina, não é considerado como elemento do ato jurídico, tampouco do ato administrativo. Afirma que "o próprio silêncio pode significar manifestação de vontade e produzir efeito jurídico, sem que corresponda a um ato administrativo".

Celso Antônio Bandeira de Mello ${ }^{39}$ também entende que o silêncio e a omissão não podem ser considerados como elementos do ato administrativo uma vez que não expressam uma declaração de vontade, que é caracterizadora de ato jurídico e, conseqüentemente, de ato administrativo.

Nas palavras do doutrinador

o silêncio não é ato jurídico. Por isto, evidentemente, não pode ser ato administrativo. Este é uma declaração jurídica. Quem se absteve de declarar, pois, silenciou, não declarou nada e por isto não praticou ato administrativo algum. Tal omissão é um 'fato jurídico' e, in casu, um 'fato jurídico administrativo'. Nada importa que a lei haja atribuído determinado efeito ao silêncio: o de conceder ou negar. Este efeito resultará do fato da omissão, como imputação legal, e não de algum presumido ato, razão por que é de rejeitar a posição dos que consideram ter aí existido um 'ato tácito'.

\footnotetext{
${ }^{37}$ Idem, ibidem, p. 498

${ }^{38}$ DI PIETRO, Maria Sylvia Zanella. Direito Administrativo, cit., p. 197

${ }^{39}$ MELLO, Celso Antonio Bandeira. Curso de Direito Administrativo, cit., p. 379
} 
Em relação à nomenclatura utilizada por Celso Antônio Bandeira de Mello, a expressão elementos tem a conotação de parte componente de um todo e, por isso, não são todos os elementos apontados pela maioria dos doutrinadores que "podem ser admitidos como "partes do ato, pois lhe são exteriores", 40 . Para ele, somente o conteúdo e a forma são realmente componentes do ato.

Referido doutrinador sistematiza o assunto diferenciando elementos de pressupostos. Elementos são conteúdo e forma. E, quanto aos pressupostos, subdivide-os em pressupostos de existência e pressupostos de validade. Os pressupostos de existência são o objeto e a pertinência do ato ao exercício da função administrativa. Os pressupostos de validade subdividem-se em pressuposto subjetivo (sujeito), pressupostos objetivos (motivo e requisitos procedimentais), pressuposto teleológico (finalidade), pressuposto lógico (causa), pressuposto formalístico (formalização). Não inclui a vontade como elemento, explicando que esta precede o ato não sendo possível considerá-la como parte dele, e tampouco como pressuposto por se tratar de realidade psicológica e não jurídica ${ }^{41}$.

Di Pietro ${ }^{42}$, ao discorrer sobre o tema elementos do ato administrativo, cita interessante analogia feita pelo autor italiano Humberto Fragola em "Gli atti amministrativi", que fala em anatomia do ato administrativo para designar os elementos que o compõem.

Cretella Júnior ${ }^{43}$, acompanhando esta terminologia, considera que a estrutura (ou anatomia) do ato administrativo é "o conjunto dos cinco elementos básicos constitutivos da manifestação da vontade da Administração, ou seja, o agente, o objeto, a forma, o motivo e o fim".

Di Pietro ${ }^{44}$ prefere falar em elementos, uma vez que esta é a terminologia consagrada no direito positivo brasileiro, por meio da Lei da Ação Popular (Lei 4.717, de 29-06-65) que em seu artigo $2^{\circ}$, ao indicar os atos nulos, menciona os cinco elementos dos atos administrativos: competência, forma, objeto, motivo e finalidade. Faz apenas uma ressalva quanto à competência, explicando ser preferível falar-se em sujeito, "já que a competência é apenas um dos atributos que ele deve ter para validade do ato; além de competente, deve ser capaz, nos termos do Código Civil”.

\footnotetext{
${ }^{40}$ Idem, ibidem, p. 358

${ }^{41}$ Idem, ibidem, p. 359

42 DI PIETRO, Maria Sylvia Zanella. Direito Administrativo, cit., p. 204

${ }^{43}$ CRETTELA JÚNIOR, José. Controle jurisdicional do ato administrativo. cit., p. 213

${ }^{44}$ DI PIETRO, Maria Sylvia Zanella, Op. cit., p. 204
} 
Diógenes Gasparini ${ }^{45}$ utiliza a expressão requisitos para designar "os componentes que o ato deve reunir para ser perfeito e válido". Não diferencia, portanto, os componentes condicionadores de existência do ato, daqueles referentes à sua validade. Elenca sete requisitos: agente público competente, finalidade, forma, motivo, conteúdo, objeto e causa.

Regis Fernandes de Oliveira ${ }^{46}$ tem o mesmo posicionamento de Celso Antônio Bandeira de Mello, apenas ressalvando sua preferência pela expressão condições de validade em substituição aos pressupostos subjetivos, objetivos e formais.

Exposta a questão quanto à terminologia adotada pelos diversos doutrinadores, passaremos a analisar detalhadamente cada um dos componentes do ato administrativo, sendo que, acompanhando orientação de Maria Sylvia Zanella di Pietro e Edmir Netto de Araújo, passaremos a denominá-los de elementos ${ }^{47}$.

\subsubsection{Sujeito}

O sujeito é a pessoa física que pratica o ato administrativo, que declara a sua vontade, elemento essencial, sem o qual o ato sequer existiria. No entanto, não se trata de qualquer pessoa física, mas somente aquele que recebe da lei a competência para prática de determinado ato.

Assim, no plano administrativo, é necessário que o sujeito que edita o ato além de ser capaz - exigência comum à pratica de todos os atos jurídicos - deve também ser competente.

Esta competência deve ser considerada em três aspectos: em relação à pessoa jurídica política, determinada pela Constituição Federal; em relação aos órgãos e servidores, constantes nas leis.

É importante ressaltar que a competência decorre sempre da lei, de forma que "somente se pode falar em incompetência propriamente dita (como vício do ato administrativo), no caso em que haja sido infringida a competência definida em lei”,48, ou

${ }^{45}$ GASPARINI, Diógenes. Direito Administrativo. cit., p. 61

${ }^{46}$ OLIVEIRA, Regis Fernandes de. Ato administrativo. 5. ed. São Paulo: Revista dos Tribunais, 2007, p. 76

${ }^{47}$ ARAÚJO. Edmir Netto de. Curso de Direito Administrativo, cit., p. 498

${ }^{48}$ DI PIETRO, Maria Sylvia Zanella. Direito Administrativo, cit., p. 206 
então, quando houver óbices à atuação do agente no caso concreto, por exemplo, quando estiver afastado (por suspensão, férias, licença) ou impedido (por parentesco próximo) ${ }^{49}$.

Considerando que a competência é conferida em benefício do interesse público, a mesma é inderrogável e somente pode ser objeto de delegação ou avocação quando não conferida com exclusividade pela lei a determinado órgão ou agente público ${ }^{50}$.

\subsubsection{Forma}

A forma, em sua concepção restrita, é o modo pelo qual o ato administrativo se exterioriza, revela sua existência no mundo jurídico ${ }^{51}$. É a roupagem de que se reveste o ato administrativo.

Como constitui elemento intrínseco do ato, sua ausência leva à inexistência do ato. Porém, sua inobservância, leva à invalidade do ato. É, portanto, pressuposto de existência e validade do ato.

Regra geral, deve ser escrita, a fim de que possa ficar documentado e passível de verificação a qualquer momento. Excepcionalmente admite-se que seja oral, como a ordem de um superior hierárquico ao seu subordinado, mímica, como é o caso do policial ordenando através de gestos o trânsito e o tráfego, ou cartazes e placas, como os que proíbem o estacionamento em determinados locais ou determinam a mão de direção nas ruas.

E a formalidade, também abrangida por esta concepção restrita, é o modo específico de apresentação da forma, como é o caso do decreto, portaria, resolução ${ }^{52}$.

Numa concepção ampla, a forma engloba tanto a exteriorização do ato (forma e formalidade) como também "todas as formalidades que devem ser observadas durante o processo de formação da vontade da Administração, e até os requisitos concernentes à publicidade do ato" ${ }^{23}$.

\footnotetext{
${ }^{49}$ MELLO, Celso Antonio Bandeira. Curso de Direito Administrativo. cit., p. 363

${ }^{50}$ DI PIETRO, Maria Sylvia Zanella. Direito Administrativo, cit. , p. 206

${ }^{51}$ Idem, ibidem, p. 209

${ }^{52}$ GASPARINI, Diógenes. Direito Administrativo. cit., p. 64

${ }^{53}$ DI PIETRO, Maria Sylvia Zanella. Op. cit., p. 209
} 
É o que Celso Antônio Bandeira de Mello ${ }^{54}$ chama de requisitos procedimentais, que ao lado do motivo constituem-se pressupostos objetivos do ato administrativo. Para ele,

requisitos procedimentais são os atos que devem, por imposição normativa, preceder a um determinado ato. Consistem em outros atos jurídicos, produzidos pela própria Administração ou por um particular. Assim, por exemplo, o ato de nomeação de um funcionário para cargo efetivo só poderá ser expedido depois da série de atos que compõem o concurso público para o qual o interessado se classificou. Igualmente, o ato de adjudicação em uma concorrência só pode ocorrer após o ato de classificação do licitante colocado em primeiro lugar. A seu turno, o ato de classificação não pode ser produzido antes do ato de habilitação do concorrente.

Tendo em vista ser a forma elemento do ato - uma vez que sua inexistência, leva a inexistência do ato - e ao mesmo tempo requisito ou pressuposto de validade - pois sua inobservância leva a invalidade do ato -, nos parece mais adequada esta concepção ampla, em que o procedimento administrativo integra o conceito de forma, uma vez que tanto a inobservância da forma ou formalidade, consideradas isoladamente, como também o não atendimento ao procedimento indicado pela lei podem levar à invalidade do ato administrativo.

\subsubsection{Motivo}

Entende-se por motivo os fundamentos de fato e de direito precedentes ao ato administrativo e justificadores de sua prática. "É o que provoca o impulso volitivo que condicionará a formação do ato", como diz Edmir Netto de Araujo ${ }^{55}$.

O fundamento ou pressuposto de fato é a situação do mundo real que deve ser considerada para o agir da Administração. O pressuposto de direito, ou motivo legal "é a previsão abstrata de uma situação fática, empírica" "56.

\footnotetext{
${ }^{54}$ MELLO, Celso Antonio Bandeira. Curso de Direito Administrativo. cit., p. 371

${ }^{55}$ ARAÚJO. Edmir Netto de. Curso de Direito Administrativo. cit., p. 501
} 
Ao analisar-se a legalidade de um ato administrativo, sob o enfoque do motivo, deve-se levar em conta a materialidade do ato, ou seja, verificar se realmente ocorreu o motivo em função do qual foi praticado o ato, bem como a correspondência entre o motivo legal e o motivo fático ${ }^{57}$.

Há distinção entre motivo e motivação. O motivo é a situação empírica (motivo fático) ou prevista de forma abstrata (motivo legal). A motivação "é a exposição dos motivos, ou seja, é a demonstração, por escrito, de que os pressupostos de fato realmente existiram" ${ }^{, 58}$. Relaciona-se às formalidades do ato.

A discussão acerca da obrigatoriedade ou não de motivação e de quais atos devem ser motivados perdeu sua contemporaneidade uma vez que ela (motivação) garante a observância da legalidade. É através dela que é possível verificar a qualquer momento a legalidade do ato ${ }^{59}$.

Celso Antônio Bandeira de Mello ${ }^{60}$ tem o mesmo posicionamento, acrescentando mais fundamentos à obrigatoriedade de motivação:

Parece-nos que a exigência de motivação dos atos administrativos, contemporânea à prática do ato, ou pelo menos anterior a ela, há de ser tido como uma regra geral, pois os agentes administrativos não são 'donos' da coisa pública, mas simples gestores de interesses de toda coletividade, esta, sim, senhora de tais interesses, visto que, nos termos da Constituição, 'todo poder emana do povo' (...) (art. 1'o parágrafo único). Logo parece óbvio que, praticado o ato em um Estado onde tal preceito é assumido e que, ademais, qualifica-se como 'Estado Democrático de Direito'(art. $1^{\circ}$, caput), proclamando, ainda, ter como um de seus fundamentos a 'cidadania'(inciso II), os cidadãos e em particular o interessado no ato têm o direito de saber por que foi praticado, isto é, que fundamentos o justificam.

${ }^{56}$ MELLO, Celso Antonio Bandeira. Curso de Direito Administrativo. cit., p. 364

${ }^{57}$ Idem, ibidem, p. 364-365

${ }^{58}$ DI PIETRO, Maria Sylvia Zanella. Direito Administrativo, cit., p. 212

${ }^{59}$ SANTOS NETO, João Antunes dos. Da anulação Ex Officio do Ato Administrativo. cit., p. 114

${ }^{60}$ MELLO, Celso Antonio Bandeira. Op. cit., p. 368 
Ainda em relação a este instituto, é importante lembrar a teoria dos motivos determinantes, que condiciona a validade do ato à verificação da ocorrência real dos motivos alegados (motivação), de forma que sendo estes inexistentes ou falsos, implicam em nulidade. Assim, mesmo não havendo previsão legal dos motivos que ensejariam a prática do ato, bem como a exigência expressa de enunciá-los, uma vez enunciados pelo agente os motivos em que se calcou, o ato só será válido se estes realmente ocorreram e o justificaram ${ }^{61}$.

A título de exemplo desta teoria, Di Pietro ${ }^{62}$ cita a exoneração ad nutum, para qual a lei não define o motivo. Neste caso, se a Administração Pública justifica o ato exoneração por falta de verba e em seguida nomeia outro servidor para o mesmo cargo, o ato será nulo por vício quanto ao motivo.

\subsubsection{Objeto}

Há divergência quanto a este elemento do ato administrativo. Parte da doutrina adota como sinônimas as expressões objeto e conteúdo, e outra parte entende tratar-se de realidades distintas.

Celso Antônio Bandeira de Mello ${ }^{63}$ não somente diferencia conteúdo e objeto, como afirma não ser o objeto elemento do ato, pois não o integra. Para ele, conteúdo é "o que o ato decide, enuncia, certifica, opina ou modifica na ordem jurídica", ou seja, é “o próprio ato, em sua essência”. A outorga de uso, por exemplo, é conteúdo do ato de permissão de uso de bem público, da mesma forma que o desligamento do agente público é conteúdo do ato de exoneração de funcionário ocupante de cargo em comissão ${ }^{64}$. E o objeto "é aquilo sobre que o ato dispõe" 65 . É a coisa sobre a qual incide o conteúdo do ato. Ressalta esta diferenciação afirmando que "se o conteúdo do ato fala sobre algo, é porque este algo constitui-se em realidade que com ele não se confunde e, de outro lado, que o objeto não é um elemento do ato, pois não o integra" ${ }^{\text {,66. }}$.

Idêntico o posicionamento de Regis Fernandes de Oliveira:

\footnotetext{
${ }^{61}$ MELLO, Celso Antonio Bandeira. Curso de Direito Administrativo. cit, p. 370

${ }^{62}$ DI PIETRO, Maria Sylvia Zanella. Direito Administrativo, cit., p. 213

${ }^{63}$ MELLO, Celso Antonio Bandeira. Op. cit., p. 360

${ }^{64}$ GASPARINI, Diógenes. Direito Administrativo. cit., 2009

${ }^{65}$ MELLO, Celso Antonio Bandeira. Op. cit., p. 361

${ }^{66}$ Idem, ibidem, p. 360
} 
O objeto, no entanto, não é elemento, nem condição de validade do ato administrativo, uma vez que se não for lícito, possível, física e juridicamente, certo e determinado, razoável e moral, a nulidade alcança o próprio conteúdo do ato. O vício não será em decorrência do objeto, mas sim em virtude da prescrição estar viciada, porque recai sobre objeto indevido. [...] O conteúdo, em suma, é o próprio ato, é a prescrição dele. Por exemplo, quando se desapropria algum imóvel, o conteúdo do ato é a própria desapropriação, enquanto seu objeto é o imóvel expropriado ${ }^{67}$.

Di Pietro ${ }^{68}$, embora reconheça esta diferenciação entre conteúdo e objeto, entende ser a mesma destituída de qualquer importância prática, pois o que importa na análise do ato administrativo é a produção de efeitos jurídicos (conteúdo para aqueles que entendem tratar-se de realidades distintas), mas em razão de ser o ato administrativo espécie de ato jurídico, prefere utilizar a mesma nomenclatura deste elemento em relação ao ato jurídico, ou seja, objeto.

Para que o ato exista e seja válido, o objeto (e o conteúdo) deve ser lícito, ou de acordo com a lei; possível, do ponto de vista fático e legal; certo, ou seja, delimitado quanto aos destinatários, aos efeitos, ao tempo e ao lugar; e moral, conforme os padrões comuns de comportamento ${ }^{69}$.

\subsubsection{Finalidade}

É o objetivo que a Administração Pública quer alcançar com a prática do ato administrativo.

Toda atuação da Administração Pública deve ser pautada no atendimento do interesse público. Sendo assim, o ato administrativo deve sempre ter uma finalidade pública. Esta é a finalidade genérica, ou em sentido amplo, que deve ser sempre de interesse público.

Há, ainda, a finalidade em sentido restrito que é o efeito específico que cada ato deve produzir. Esta finalidade é determinada pela lei de forma implícita ou explícita.

${ }^{67}$ OLIVEIRA, Regis Fernandes de. Ato administrativo, cit., p. 80-81

${ }^{68}$ DI PIETRO, Maria Sylvia Zanella. Direito Administrativo, cit., p. 208

${ }^{69}$ Idem, ibidem, p. 208 
Desta forma, qualquer ato administrativo terá uma finalidade genérica, de interesse público, e uma finalidade específica imposta pela lei. Caso o resultado objetivado esteja em desacordo seja com a finalidade de interesse público, seja com a finalidade legal, o ato será ilegal por desvio de finalidade.

Régis Fernandes de Oliveira ${ }^{70}$ distingue a finalidade do fim do ato administrativo. Para ele, o fim é imediato, "é o que se objetiva na realização prática da atividade administrativa" e a finalidade, sempre mediata, "é o determinado no contexto normativo como de interesse do Estado". Elucida através do seguinte exemplo:

Estabelece o ordenamento jurídico que o Estado deva cuidar da segurança pública (finalidade ou fim remoto ou mediato). Em determinada situação fática, impõe-se a construção de um quartel em zona fronteiriça, diante da invasão inimiga (fim - criação do quartel para evitar a invasão) .

Assim, a finalidade equivaleria à finalidade genérica e o fim à finalidade específica.

Alguns autores ${ }^{71}$ apontam, ainda, a causa como elemento do ato administrativo. Esta consiste na adequação lógica entre o motivo e o conteúdo. $\mathrm{O}$ ato de transferência do servidor público (conteúdo) para outro setor, terá uma causa válida se existir uma necessidade do serviço (motivo). No entanto, se o que se pretende é aplicar uma punição, a causa será inválida, uma vez que não haverá esta adequação entre o motivo (prática de infração administrativa) e o conteúdo (transferência do servidor).

\subsection{Atributos do ato administrativo}

Uma vez concluído o processo de formação do ato administrativo, conforme visto no item anterior, ele está apto a produzir seus efeitos jurídicos. A fim de que estes efeitos jurídicos sejam eficazes, o ordenamento jurídico os dota de algumas características, desconhecidas das relações entre particulares, que são chamados de atributos do ato administrativo.

${ }^{70}$ OLIVEIRA, Regis Fernandes de. Ato administrativo. cit., p. 82

${ }^{71}$ OLIVEIRA, Regis Fernandes de. Ato administrativo. cit., p.85; MELLO, Celso Antonio Bandeira. Curso de Direito Administrativo. cit., p. 374; GASPARINI, Diógenes. Direito Administrativo. cit., p.68 
Atributos são, portanto, as características do ato administrativo que contribuem para realização concreta de sua finalidade e fundamentam-se no princípio da supremacia do interesse público ${ }^{72}$.

Enquanto os elementos e requisitos do ato dizem respeito à sua existência e validade, os atributos relacionam-se à sua eficácia.

Aqui também não se encontra pacificada a doutrina quanto à indicação de quais seriam estes atributos. No entanto, ao menos três deles são indicados pela maioria dos administrativistas: imperatividade, presunção de legitimidade e a auto-executoriedade.

\subsubsection{Imperatividade}

A imperatividade é o atributo do ato administrativo que torna obrigatórios os comandos por ele emitidos. Não está presente em todos os atos administrativos, somente naqueles que impõem uma obrigação, como, por exemplo, o ato que institui uma servidão ou o que submete um bem à força expropriatória.

\subsubsection{Presunção de legitimidade}

A presunção de legitimidade diz respeito ao ato administrativo ser considerado válido e verdadeiro até que se prove o contrário. Este atributo decorre do princípio da legalidade e da finalidade, pois estando a Administração Pública obrigada a agir nos termos prescritos pelo ordenamento jurídico, e sempre buscando atingir uma finalidade de interesse público, os atos por ela (Administração Pública) praticados, são presumidos legítimos e verdadeiros. Este atributo traz como consequência a desnecessidade de o agente que pratica o ato provar sua legitimidade. Há, portanto, a inversão do ônus da prova. Aquele que se sentir prejudicado pelos efeitos do ato administrativo ilegítimo é que deve provar tal ilegalidade.

\subsubsection{Auto-executoriedade}

A auto-executoriedade diz respeito ao poder-dever de a Administração Pública executar seus próprios atos de forma imediata, sem depender de autorização

${ }_{72}$ ARAÚJO. Edmir Netto de. Curso de Direito Administrativo, cit., p. 500 
judicial para tanto. Este atributo justifica-se pelo fato de que a realização do interesse público "não pode e não deve sujeitar-se à participação dos destinatários ou de outros Poderes para concretizar-se" ${ }^{73}$. Não é atributo de todo ato administrativo. Somente possuem tal atributo, os atos que a lei assim os determinarem, ou os necessários a salvaguarda de um interesse público ameaçado. Nesta hipótese, a autorização para a autoexecutoriedade encontra-se implícita no sistema legal, uma vez que a Administração é a responsável pela proteção do bem jurídico posto em risco.

${ }^{73}$ ARAÚJO. Edmir Netto de. Curso de Direito Administrativo, cit., p. 500 


\section{ATO ADMINISTRATIVO INVÁLIDO}

Em que pese a submissão da Administração Pública ao principio da legalidade, nem sempre se verifica sua atuação nos termos determinados pelo ordenamento jurídico, ocasionando a produção de um ato administrativo inválido.

Assim como no Direito Civil, em que os vícios se referem aos três elementos do ato jurídico - sujeito, forma e objeto -, no Direito Administrativo os vícios podem atingir os cinco elementos do ato administrativo, caracterizando os vícios quanto ao sujeito, à forma, ao objeto, ao motivo e à finalidade.

\subsection{Vícios relativos ao sujeito}

Sob este aspecto, o ato administrativo pode apresentar vícios relativos à competência ou à capacidade do agente.

$\mathrm{O}$ defeito relativo à competência do agente ocorre quando $\mathrm{o}$ ato administrativo é praticado com usurpação de função, abuso de função, e invasão de função ${ }^{1}$.

A usurpação de função ocorre quando a pessoa que pratica o ato é destituída de qualquer investidura em função pública. Ela se apossa, por conta própria, de uma função pública. Configura crime definido pelo artigo 328, do Código Penal. Os atos praticados pelo usurpador de função são juridicamente inexistentes e o usurpador não tem direito a qualquer indenização em razão da função exercida ilegalmente, salvo se o patrimônio administrativo enriqueceu com sua conduta ${ }^{2}$.

Há que se distinguir a figura do usurpador de função do chamado funcionário de fato. Enquanto o usurpador de função não possui qualquer investidura, seja ela regular ou irregular, o funcionário de fato encontra-se investido no cargo, emprego ou função, porém, de forma irregular. Outro elemento diferenciador diz respeito a aparência de legalidade. Os atos praticados pelo funcionário de fato tem toda aparência de legalidade, e por isso são considerados válidos. O mesmo não ocorre com os editados pelo usurpador de função, que por não terem qualquer aparência de legalidade, são tidos por inexistentes.

\footnotetext{
${ }^{1}$ CRETTELA JÚNIOR, José. Controle jurisdicional do ato administrativo. 3. ed. Rio de Janeiro: Forense, 2001, p. 257

${ }^{2}$ Idem, ibidem, p. $259-260$
} 
O abuso de função ocorre quando há uma exorbitância do agente no exercício de suas atribuições. O agente, embora legítimo, exerce funções além dos parâmetros legais fixadores de sua competência. Cretela Júnior $^{3}$ exemplifica com a autoridade que, embora competente para aplicar a pena de suspensão, impõe penalidade mais grave, sendo que essa pena mais grave não se enquadra em sua competência funcional, ou também quando a autoridade policial se excede no uso da força na prática de ato inserido em sua competência.

A invasão de função ocorre quando o agente, além de exorbitar o exercício de suas funções, penetra na esfera privativa de outro funcionário dentro do mesmo Poder (invasão de função relativa) ou de outro Poder (invasão de função absoluta).

Os vícios relativos à capacidade são os descritos nos artigos $3^{\circ}$ e $4^{\circ}$, do Código Civil de 2002, e os resultantes dos chamados vícios de consentimento - o erro, o dolo, a coação, a simulação e a fraude.

Os vícios de consentimento, no âmbito do Direito Civil podem acarretar a nulidade absoluta ou relativa. $\mathrm{O}$ mesmo não ocorre em relação ao ato administrativo, uma vez que este se submete a regime jurídico de direito público, a exigir a utilização de outros critérios indicadores das condições de validade ${ }^{4}$.

Além da capacidade geral, nos termos do Direito Civil, existem no Direito Administrativo duas outras hipóteses de incapacidade, descritas na Lei 9.784/99 (Lei do Processo Administrativo Federal): o impedimento e a suspeição.

O impedimento gera uma presunção absoluta de incapacidade, ficando o agente público proibido de atuar no processo, e a suspeição gera uma presunção relativa de incapacidade, restando sanado o vício se não for arguido pelo interessado no momento oportuno. Ambas as hipóteses, no Direito Administrativo, são passíveis de convalidação por autoridade que não esteja na mesma situação de impedimento ou suspeição ${ }^{5}$.

\footnotetext{
${ }^{4}$ SANTOS NETO, João Antunes dos. Da Anulação Ex Offício do Ato Administrativo. cit., p.126

${ }^{5}$ DI PIETRO, Maria Sylvia Zanella. Direito Administrativo. 24. ed. São Paulo: Atlas, 2011, p. 243
} 


\subsection{Vícios relativos ao objeto}

Conforme ressaltado, quando da análise dos elementos do ato administrativo, o objeto deve ser lícito, possível, moral e determinado. Desta forma, o vício em relação ao objeto ocorrerá pela inobservância de qualquer um destes requisitos.

Haverá vício relativo ao objeto quando este for proibido por lei, a exemplo do que ocorre quando um Município desapropria bem imóvel da União; quando diverso da previsão legal para o caso sobre o qual incide, a exemplo da autoridade administrativa que aplica pena de suspensão quando a cabível seria de advertência; quando impossível, como a nomeação para cargo inexistente; quando for imoral, como o parecer emitido sob encomenda, contrário ao entendimento de quem o profere; ou quando incerto em relação aos destinatários, às coisas, ao tempo, ao lugar, por exemplo, a desapropriação de bem não definido com precisão ${ }^{6}$.

\subsection{Vícios relativos à forma}

O defeito de forma consiste na inobservância dos requisitos extrínsecos previstos em lei para o ato específico. Este vício terá consequências maiores ou menores conforme o bem tutelado.

A forma pode ser estabelecida objetivando uma mera padronização de operações rotineiras da Administração Pública, ou então, como garantia aos direitos dos cidadãos, ou ainda, em função dos altos interesses da Administração Pública. Nestas duas últimas hipóteses, quando inobservada, acarreta a invalidade do ato. Quando sua omissão não causar prejuízo a terceiros ou à própria Administração, haverá mera irregularidade, passível de correção, sem gerar maiores consequências.

Relacionado ao vício de forma está o vício relativo ao procedimento.

Procedimento é conjunto de atos que antecedem o ato administrativo final. A doutrina, ao tratar da processualidade administrativa vem atribuindo grande importância a estes atos que contribuem para a formação da vontade administrativa. $\mathrm{O}$ procedimento serve tanto para permitir um controle do ato administrativo pelos administrados, como também para assegurar o cumprimento de princípios constitucionais. Pode-se citar, a título de exemplo, o procedimento licitatório que antecede o contrato

\footnotetext{
${ }^{6}$ DI PIETRO, Maria Sylvia Zanella. Direito Administrativo. 24. ed., São Paulo: Atlas, 2011, p. 244
} 
administrativo e tem como principal objetivo garantir a observância do principio constitucional da isonomia ${ }^{7}$.

Desta forma, a inobservância do procedimento, assim como a adoção de outro que não o adequado geram invariavelmente a invalidação do ato administrativo do qual se originaram. Já o vício de forma, dependendo da gradação do interesse lesado, pode não levar à invalidação do ato $^{8}$.

\subsection{Vícios relativos ao motivo}

O vício quanto ao motivo pode ocorrer quando este é inexistente ou falso. Por exemplo, quando se aplica uma sanção disciplinar a um servidor sob a alegação de o mesmo ter faltado sucessivamente ao serviço e verifica-se que tal fato não ocorreu, está-se diante de um ato com motivo inexistente. Por outro lado, se o servidor embora tenha cometido infração disciplinar esta foi diversa do alegado, o ato de punição será viciado por motivo falso 9 .

\subsection{Vícios relativos à finalidade}

$\mathrm{O}$ vício relativo à finalidade do ato ocorre quando o agente público, investido de sua competência, pratica determinado ato administrativo visando obter um resultado diverso daquele previsto na lei.

É o que se chama de desvio de finalidade, ou desvio de poder, que se caracteriza quando "a autoridade, que tem competência ou poder para a edição de determinado ato, manifesta a vontade, praticando-o, dando-lhe nascimento, mas nessa operação, erra de alvo, afasta-se do fim colimado para perseguir finalidade diversa da visada" $" 10$.

\footnotetext{
${ }^{7}$ SILVA, Clarissa Sampaio. Limites à invalidação dos atos administrativos. São Paulo: Max Limonad, 2001, p.75

${ }^{8}$ Idem, ibidem, p.76

${ }^{9}$ CRETTELA JÚNIOR, José. Controle jurisdicional do ato administrativo. cit., p. 267

${ }^{10}$ Idem, ibidem, p. 273
} 
Para Celso Antônio Bandeira de Mello é "o manejo de uma competência em descompasso com a finalidade em vista da qual foi instituída"11.

A teoria do desvio de poder originou-se na França, com o caso Lesbats. O prefeito de Leine-et-Marne, baseado em seu poder de polícia de regular a circulação e estacionamento de veículos nos arredores das estações de trens, conferiu com exclusividade a uma única empresa o direito de acesso às vagas reservadas pela estação de trens de Fontainebleu, justificando tal medida no interesse público de se evitar a obstrução daquela estação. O Sr. Lesbats, que teve a sua autorização de entrada no estacionamento dos ônibus da estação ferroviária recusada, recorreu e ganhou no Conselho de Estado, o direito de também usufruir do respectivo estacionamento, extinguindo-se o convênio que estabelecia o monopólio de somente um contratado.

No Brasil, decisão pioneira que acolheu a teoria do desvio de finalidade foi proferida em mandado de segurança em 28 de julho de 1948 pelo Tribunal de Justiça do Rio Grande do Norte. Nesta decisão, ficou reconhecido que a autoridade administrativa, no uso de sua atribuição de polícia, ao fixar horário para tráfego de determinada empresa de ônibus, prejudicando-a em benefício de outra empresa, incidiu em desvio de finalidade, uma vez que não houve qualquer melhoria do serviço público de transporte coletivo caracterizando a real intenção da autoridade em atender seu interesse pessoal, no sentido de beneficiar aquela empresa.

Conforme visto em capítulo anterior, todo ato administrativo tem uma finalidade genérica e uma específica, que podem ou não constar de forma expressa na lei. Desta forma, o desvio de finalidade também poderá ser genérico ou específico.

Configura-se o desvio de finalidade genérico quando o administrador, usando de sua competência legal, pratica ato visando o atingimento de um interesse particular. Desvia-se, portanto, de uma finalidade de interesse público, buscando a satisfação de interesse privado.

O desvio de finalidade específico ocorre quando o ato administrativo, embora atenda genericamente um interesse público, tem finalidade diversa daquela prevista pelo legislador. Por exemplo, o ato de remoção de um servidor tem como finalidade específica a melhoria do serviço público; se a autoridade administrativa remove

${ }^{11}$ MELLO, Celso Antonio Bandeira. Curso de Direito Administrativo. 17. ed. São Paulo: Malheiros, 2004, p.862 
o servidor com o objetivo de aplicar uma penalidade, há desvio de finalidade específica. Isso porque, se o que se pretende (finalidade) é a punição deve-se se utilizar o ato adequado para tal fim.

Ambas espécies de desvio de finalidade causam a nulidade do ato administrativo, embora exista um abrandamento dos efeitos na invalidação de ato administrativo com desvio de finalidade específica, admitindo-se a manutenção dos efeitos que envolvam algum proveito para a coletividade ${ }^{12}$.

Celso Antônio Bandeira de Mello ${ }^{13}$ entende que a identificação do vício de finalidade ocorre pela verificação concreta do resultado efetivamente alcançado, pouco importando se o agente pretendeu ou não discrepar da finalidade legal, mas se efetivamente dela discrepou. Para ele, a intenção do agente constitui-se apenas como elemento revelador do vício.

Opinião contrária é defendida por João Antunes dos Santos Neto ${ }^{14}$, a qual nos filiamos. Para ele, o vício de finalidade tem natureza subjetiva, ou seja, para caracterização do vício basta a constatação de que o agente ao praticar o ato teve intenção em atingir finalidade diversa da prevista em lei, pouco importando o resultado atingido pelo ato.

Para ilustrar, citemos o seguinte exemplo: Um prefeito, alegando a necessidade de ampliar a rede de ensino municipal, desapropria imóvel, cuja propriedade é de seu inimigo político, com a real intenção de prejudicá-lo. Neste caso, desde que comprovada sua real intenção, haverá desvio de finalidade, independentemente da comprovação de ter ou não prejudicado o proprietário do imóvel.

Considerando que a finalidade é o resultado da ação do agente público, muitas vezes, quando constatado o vício quanto a este elemento, o mesmo já ocorreu em momento anterior à formação do ato, seja quanto ao motivo, a competência, ao conteúdo ou à forma. Assim, conforme lições de Edmir Netto de Araújo"15, "só existirá mesmo, defeito propriamente dito referível à finalidade, por erro ou dolo quanto à valoração do interesse público de que se trata, ou quando, no lapso entre a formação do ato e a

${ }_{12}$ MOTTA, João Francisco da. Invalidação dos atos administrativos. Belo Horizonte: Del Rey, 2010, p. 60

${ }^{13}$ MELLO, Celso Antonio Bandeira. Curso de Direito Administrativo. cit., p. 863

14 SANTOS NETO, João Antunes dos. Da anulação Ex Offício do Ato Administrativo. Belo Horizonte: Fórum, 2004, p. 132

${ }^{15}$ ARAÚJO. Edmir Netto de. Curso de Direito Administrativo. 6. ed. São Paulo: Saraiva, 2014, p. 521-522 
realização efetiva de sua finalidade, tal interesse público deixar de existir, ou deixar de ser válido".

\subsection{Teoria das nulidades}

Concomitantemente ao desenvolvimento da noção de ato jurídico, estudado pela Teoria Geral do Direito, construiu-se uma teoria sobre as nulidades de tais atos, buscando explicar as consequências geradas por aqueles atos produzidos com defeito, seja pela ausência de seus elementos formadores, seja pela inobservância de seus requisitos juridicamente determinados ${ }^{16}$.

\subsubsection{Transposição da teoria das nulidades do Direito Civil para o}

\section{Direito Administrativo}

Tendo em vista a precedência histórica do Direito Civil, foi no âmbito deste ramo do Direito que teve início a elaboração das teorias sobre os atos nulos, anuláveis e inexistentes.

Com o desenvolvimento do Direito Administrativo, e a necessidade de se estabelecer uma consequência jurídica para os atos administrativos editados em desconformidade com o ordenamento jurídico, buscou-se transpor os conceitos formulados pelo Direito Civil, quanto à teoria das nulidades, para o Direito Administrativo, o que suscitou inúmeras discussões.

Alguns autores consideram impraticável a transposição, pura e simples, para o Direito Público, da teoria das nulidades desenvolvidas pelo Direito Civil.

As principais divergências ocorrem em função dos efeitos da invalidação, uma vez que no Direito Administrativo há uma constante tensão entre o princípio da legalidade, que exige que o ato administrativo esteja em conformidade com a lei e o princípio do interesse público, que impõe a conformidade do ato administrativo com o interesse da coletividade ${ }^{17}$.

\footnotetext{
${ }^{16}$ Horbach, Carlos Bastide. Teoria das nulidades do ato administrativo. São Paulo: Revista dos Tribunais, 2007

${ }^{17}$ REALE, Miguel. Revogação e anulamento do ato administrativo. $2^{\mathrm{a}}$. ed. Rio de Janeiro: Forense, 1980, p. 47
} 
Seabra Fagundes, embora reconheça a utilidade e importância do Direito Civil na elaboração doutrinaria do Direito Administrativo, afirma ser inconciliável a transplantação dos princípios civilistas para o Direito Administrativo, em especial os que regem a teoria das nulidades.

Para este doutrinador, o acolhimento da classificação dicotômica do Direito Civil, "reduz-se quase unicamente ao uso das denominações ali adotadas" ${ }^{18}$. Isto porque, o ato jurídico civil diferencia-se substancialmente do ato jurídico administrativo. A principal diferença se verifica em relação aos interesses atingidos por um e outro. $\mathrm{O}$ ato administrativo, ao fundamentar-se sempre no atingimento de um interesse público, acaba por afetar vários interesses. $\mathrm{O}$ ato jurídico privado tendo como objetivo imediato atender a um interesse particular, produz efeitos restritos aos interesses dos seus participantes diretos ${ }^{19}$.

Ainda em relação à inaplicabilidade dos conceitos de Direito Civil sobre as nulidades no Direito Administrativo, o mesmo autor aponta diferenças inconciliáveis em relação ao pronunciamento das nulidades pelo Poder Judiciário, à possibilidade de convalidação do ato e às causas que geram a nulidade ou anulabilidade.

A nulidade absoluta do ato jurídico privado (ato nulo) deve ser pronunciada de ofício pelo Juiz. O mesmo não ocorre em relação ao ato administrativo viciado, uma vez que pela sua presunção de legitimidade o vício somente pode ser decretado de ofício pelo Juiz em casos excepcionais.

Admite-se no âmbito do Direito Civil a convalidação do ato anulável, uma vez que este envolve somente o interesse das partes mas, na opinião do autor, isto não seria possível em relação ao ato administrativo por este envolver direitos de vários indivíduos ${ }^{20}$.

No Direito Civil, o ato praticado pelo absolutamente incapaz - menores de 16 anos, loucos de todo gênero, surdos-mudos que não puderem exprimir sua vontade e os ausentes declarados tais por ato do juiz - é nulo e como tal não produz qualquer efeito jurídico.

\footnotetext{
${ }^{18}$ FAGUNDES, Miguel Seabra. O controle dos atos administrativos pelo Poder Judiciário. $8^{\circ}$. ed. Rio de Janeiro: Forense, 2010, p. 59-60

${ }^{19}$ Idem, ibidem, p. $52-53$

${ }^{20}$ Idem, ibidem, p. 59
} 
No Direito Administrativo, o vício mais evidente em relação à capacidade que gera a nulidade do ato ocorre por defeito da investidura (funcionário de fato), ou pela exorbitância das atribuições legalmente prefixadas (incompetência). Referese não à pessoa em si, mas às prescrições legais sobre o ingresso em cargo público e o desempenho de funções públicas. Por razões de interesse público, os efeitos dos atos administrativos praticados com tais vícios podem subsistir ${ }^{21}$.

Percebe-se, assim, mais uma incompatibilidade entre os conceitos de nulidade do ato jurídico privado e do público. Os efeitos do ato jurídico administrativo, mesmo quando viciado, podem persistir por razões de interesse público (estabilidade, certeza e confiança nas relações do indivíduo com a Administração). O mesmo não ocorre com o ato jurídico privado nulo, pois este não produz qualquer efeito jurídico ${ }^{22}$.

Maria Sylvia Zanella Di Pietro ${ }^{23}$, além de concordar com a impossibilidade de transposição da teoria das nulidades formulada pelo Direito Civil para o Direito Administrativo, oferece uma solução ao afirmar que o estudo de determinado ramo do Direito deve ser feito à partir de "institutos definidos pela Teoria Geral do Direito e que corresponde as chamadas categorias jurídicas", que nas palavras de José Cretella Júnior, são "uma formulação genérica, in abstracto, com índices essenciais, mas gerais, não comprometida ainda com nenhum dos ramos do direito" 24 .

Desta forma, a teoria das nulidades no Direito Administrativo deve ser estudada inicialmente sob a ótica da Teoria Geral do Direito, promovendo-se as necessárias adaptações, de acordo com as particularidades deste ramo da ciência jurídica ${ }^{25}$.

E o que se extrai da Teoria Geral do Direito, em relação aos atos inválidos, é que os mesmos não apresentam alguns pressupostos determinados pela lei, para serem considerados válidos e podem ser extintos em razão desta contrariedade à lei ou gerar responsabilização da pessoa que o produziu ${ }^{26}$.

\footnotetext{
${ }^{21}$ Idem, ibidem, p. 62-63

22 Idem, ibidem, p. 63

${ }^{23}$ DI PIETRO, Maria Sylvia Zanella. Ainda existem os contratos administrativos? In: DI PIETRO, Maria Sylvia Zanella, e RIBEIRO, Carlos Vinícius Alves. Supremacia do interesse público e outros temas relevantes do direito administrativo. São Paulo: Atlas, 2010, p. 399

${ }^{24}$ CRETELLA JÚNIOR, José. As categorias jurídicas e o direito publico. Revista da Faculdade de Direito da USP, ano LXII, fasc. II, 1967 apud DI PIETRO, Maria Sylvia Zanella. Ainda existem os contratos administrativos? In: DI PIETRO, Maria Sylvia Zanella, e RIBEIRO, Carlos Vinícius Alves. Supremacia do interesse público e outros temas relevantes do direito administrativo. São Paulo: Atlas, 2010, p. 399

${ }^{25}$ REALE, Miguel. Revogação e anulamento do ato administrativo, cit., p. 47

${ }^{26}$ SUNDFELD, Carlos Ari. Ato administrativo inválido. São Paulo: Revista dos Tribunais, 1990, p. 39
} 
Para Sundfeld ${ }^{27}$ também não há possibilidade de transposição para o Direito Administrativo da distinção entre atos nulos e anuláveis do Direito Civil por duas razões: o Direito Civil utiliza, sob um mesmo critério, diversas questões - quais atos podem ser ratificados, quem está legitimado para provocar a invalidação, quais espécies de vícios podem ser decretados de ofício pelo juiz e qual o prazo prescricional de invalidação - e estas são em sua maioria questões de Direito Adjetivo. Ao mesmo tempo, reconhece a utilidade das questões enfeixadas por esta distinção para se analisar as invalidades no Direito Administrativo, propondo uma análise segmentada, tal como a matéria é tratada pelo Direito positivo.

Desta forma, na seara do Direito Administrativo os atos administrativos inválidos devem ser estudados no que diz respeito à possibilidade de ratificação, legitimidade para provocar invalidação, atuação de ofício do juiz e prazos prescricionais.

\title{
2.6.2. Posição de Hely Lopes Meirelles
}

Hely Lopes Meirelles ${ }^{28}$, sustenta que qualquer ilegalidade no ato administrativo é causa de nulidade, não se admitindo atos anuláveis no campo do Direito Administrativo. Todo ato inválido é nulo. Conforme o mencionado autor,

\begin{abstract}
A nulidade (absoluta) e a anulabidade (relativa) assentam, respectivamente, na ocorrência do interesse público e do interesse privado na manutenção ou eliminação do ato irregular. Quando o ato é de exclusivo interesse dos particulares - o que só ocorre no Direito Privado , embora ilegítimo ou ilegal, pode ser mantido ou invalidado segundo o desejo das partes; quando é de interesse público - e tais são todos os atos administrativos -, sua legalidade impõe-se como condição de validade e eficácia do ato, não se admitindo o arbítrio dos interessados para sua manutenção ou invalidação, porque isto ofenderia a exigência de legitimidade da atuação pública.
\end{abstract}

Embora tenha mudado seu posicionamento anterior, passando a reconhecer a possibilidade de convalidação dos atos administrativos inválidos, em face do

\footnotetext{
${ }^{27}$ Idem, ibidem, p. 41-42

${ }^{28}$ MEIRELLES, Hely Lopes. Direito Administrativo Brasileiro. 25. ed., São Paulo: Malheiros, 2000, p. 194
} 
disposto no artigo 55, da Lei 9.784/99 (Lei do Processo Administrativo Federal) -, que prevê expressamente a possibilidade de convalidação do ato administrativo inválido que não atente contra interesse público ou cause prejuízo a terceiros -, continua a não aceitar o ato administrativo anulável.

\subsubsection{Posição de Oswaldo Aranha Bandeira de Mello}

Oswaldo Aranha Bandeira de Mello, influenciado pelas concepções civilistas sobre nulidade do ato administrativo, entende ser aplicável ao Direito Administrativo a teoria das nulidades, uma vez que as normas contidas no Direito Civil provêm da Teoria Geral do Direito.

Para este autor, ato nulo é aquele praticado por pessoa jurídica sem atribuição legal, por órgão incompetente, por usurpador de função pública, com objeto ilícito ou impossível por afronta à lei, ou pelo descumprimento de formalidade essencial. E o ato anulável é aquele praticado por agente incompetente, dentro do mesmo órgão especializado, ou com vício de vontade decorrente de erro, dolo, coação moral ou simulação ${ }^{29}$.

\subsubsection{Posição de Rui Cirne Lima}

Rui Cirne Lima também adota a sistematização das nulidades do Direito Civil, considerando ato nulo aquele que decorra de incompetência absoluta do agente ou incapacidade absoluta do co-contratante, tenha objeto ilícito ou impossível, adote forma não autorizada em lei, com preterição de solenidade considerada essencial à sua validade ou ineficácia textualmente declarada. E ato anulável aquele decorrente de incompetência relativa do agente ou incapacidade relativa do co-contratante, vício resultante de erro, dolo, coação, simulação ou fraude ${ }^{30}$.

\footnotetext{
${ }^{29}$ MELLO, Oswaldo Aranha Bandeira de. Principios Gerais de Direito Administrativo. $3^{\circ}$ ed. São Paulo: Malheiros, 2007, p. 655

${ }^{30}$ LIMA, Rui Cirne. Princípios de Direito Administrativo. $5^{\circ}$ ed. São Paulo: Revista dos Tribunais, 1982, p. 94
} 


\subsubsection{Posição de Miguel Seabra Fagundes}

Para Miguel Seabra Fagundes, as invalidades do ato administrativo se subdividem em três categorias: atos absolutamente inválidos (ou nulos), relativamente inválidos (ou anuláveis) e atos irregulares. O elemento diferenciador entre eles é a verificação, diante de razões concretamente consideradas, da intensidade de afronta ao interesse público. Assim, os atos absolutamente nulos são aqueles em que os vícios, incidentes sobre qualquer um dos elementos do ato, são de tal gravidade que não comportam tolerância. Já os atos relativamente nulos, pela menor gravidade de infringência do interesse público, comportam tolerância. E os atos irregulares seriam os portadores de defeitos irrelevantes, incapazes de gerar a extinção do ato administrativo. Verifica-se, portanto, conforme afirma o próprio autor que atos eivados de vícios substancialmente idênticos, podem acarretar resultados antagônicos ${ }^{31}$.

\subsubsection{Posição de Celso Antônio Bandeira de Mello}

Celso Antônio Bandeira de Mello reconhece quatro tipos de atos inválidos: atos inexistentes, atos nulos, atos anuláveis, atos irregulares.

Considerando ser esta a forma mais abrangente de sistematizar os atos inválidos, passaremos, então, estudar detalhadamente, cada uma destas espécies com os diferentes critérios utilizados pela doutrina para diferenciá-los.

\subsection{Atos inexistentes, nulos, anuláveis, irregulares}

Uma das questões controvertidas diz respeito ao ato inexistente. Muito se questiona acerca de serem ou não um “tertium genus" às categorias tradicionais dos atos nulos e anuláveis, reputando-se a eles qualificação jurídica de atos inválidos.

Não se pode adotar uma solução simplista afirmando que por serem inexistentes não constituem categoria suscetível de qualificação jurídica, uma vez que por possuírem uma pseudo pretensão referida ao Direito, impõe aos administradores e juízes o dever de lhes dar uma qualificação, ainda que negativa, distinguindo o que é nulo de pleno

\footnotetext{
${ }^{31}$ FAGUNDES, Miguel Seabra. O controle dos atos administrativos pelo Poder Judiciário. cit., p. 54-59.
} 
direito e o que não chegou a preencher o mínimo de pressupostos fáticos exigíveis no mundo jurídico ${ }^{32}$.

No âmbito do Direito Administrativo, a utilidade da aplicação da teoria do ato administrativo inexistente consiste na fixação do regime jurídico aplicável ${ }^{33}$.

Miguel Reale ${ }^{34}$ comenta que o conceito de ato inexistente dado por alguns autores, dentre os quais, Pontes de Miranda, é alargado em demasia por considerar que ato inexistente é aquele que fica fora do mundo jurídico, de forma que "dele se pode falar, de dentro do direito, como, de dentro de casa, se pode falar do que se passa ou se passou na rua",35.

Refutando tal conceito, o mesmo autor demonstra que em razão do ato inexistente suscitar uma pretensão jurídica, embora infundada, é necessário uma tomada negativa de posição, ou seja, "declarar que os atos inexistentes são juridicamente inválidos." E acrescenta que, "a eles nos referimos, não como, 'de dentro de casa, se possa falar do que se passa ou se passou na rua', mas sim como a algo que esbarra à nossa porta com absurda pretensão de entrar",36.

Para Miguel Reale ${ }^{37}$, atos inexistentes são atos juridicamente inválidos, da mesma forma que o são os atos nulos. A diferença entre ambos é que "enquanto o ato inexistente carece de algum elemento constitutivo e permanece juridicamente embrionário, o ato nulo reúne todos os requisitos aparentes de uma realidade jurídica, mas inidôneos, como tais, a produzir efeitos válidos, desde o seu nascimento".

Discordando desta afirmação, Sundfeld ${ }^{38}$ diferencia a inexistência da invalidade do ato administrativo, não acatando ser a inexistência um nível mais grave de invalidade, tampouco caracterizar-se por ausência de algum elemento do ato. Inicialmente, explica tratarem-se de institutos que se encontram em planos diferentes, de forma que se pode falar em ato existente e inválido. E se o ato for inexistente, não há que cogitar-se de sua validade ou invalidade.

${ }^{32}$ REALE, Miguel. Revogação e anulamento do ato administrativo. cit., p. 48

${ }^{33}$ GUALAZZI, Eduardo Lobo Botelho. Ato administrativo inexistente. São Paulo: Revista dos Tribunais, 1980 , p. 24

${ }^{34}$ REALE, Miguel. Revogação e anulamento do ato administrativo. cit., p. 49

${ }^{35}$ Pontes de Miranda, Tratado de Direito Privado, 1954, vol. IV, p. 19 apud Reale, Miguel. Revogação e anulamento do ato administrativo. $2^{\mathrm{a}}$ ed. Rio de Janeiro: Forense, 1980, p. 49

${ }^{36}$ REALE Miguel. Op. cit., p. 49

${ }^{37}$ Idem, ibidem, p. 51

${ }^{38}$ SUNDFELD, Carlos Ari. Ato administrativo inválido. São Paulo: Revista dos Tribunais, 1990, p. 15-16 
Este doutrinador relaciona a existência do ato jurídico à sua efetividade. O que a contrario sensu, nos permite concluir que o ato jurídico inexistente é aquele ao qual não é conferida efetividade.

O mesmo autor explica, ainda, que a existência do ato é conferida pela sua qualidade de norma jurídica e, esta pode existir ou porque é válida, ou seja, está conforme as disposições do sistema, que estabelecem as condições de sua produção ou porque, embora inválida, portanto, inadmitida pelo sistema, a ordem por ela proferida é socialmente reconhecida como norma jurídica.

Nas palavras desse doutrinador:

Uma ordem inexistirá juridicamente se, além de inadmitida pelas normas do sistema, for desconhecida como tal pelos destinatários. Neste caso, estar-se-á ante algo que existe faticamente, mas não juridicamente: logo, não haverá ato jurídico. Quando uma ordem estiver conforme às normas do sistema ou, estando desconforme, obtiver acatamento, constituirá ato jurídico: um ato jurídico válido, no primeiro caso; um ato jurídico inválido, no segundo ${ }^{39}$.

A expressão ato inexistente tem o sentido de ser ele destituído de qualquer relevância jurídica, e por isso não há necessidade de uma declaração formal, seja da autoridade administrativa ou judiciaria.

Ao contrário, o ato nulo, considerando que o mesmo "reúne todos os requisitos aparentes de uma realidade jurídica [...] torna-se imprescindível a decretação da nulidade, pois há sempre uma aparência a destruir" ${ }^{\text {"40 }}$.

Todos os atos praticados pela Administração Pública, tendo em vista sua submissão ao princípio da legalidade, devem observar os objetivos determinados pela lei. O distanciamento de tais objetivos pode gerar a produção de atos nulos ou anuláveis, conforme a gravidade da infração.

Nos atos nulos, é a própria lei, em sua essência que é ferida. A aferição da nulidade, também chamada de nulidade de pleno direito, ocorre de forma objetiva, por

${ }^{39}$ SUNDFELD, Carlos Ari. Ato administrativo inválido. cit., p. 21-22

${ }^{40}$ REALE, Miguel. Revogação e anulamento do ato administrativo. cit., p. 51-52 
um processo de mera subsunção normativa, em que se verifica claramente uma incompatibilidade lógica entre um fato e sua respectiva solução normativa ou consequência de direito ${ }^{41}$. Isso permite que a Administração tenha "condições de formar um juízo seguro sobre a invalidade do ato, independentemente de processo contencioso" ${ }^{\star 2}$. Daí a razão de se afirmar que as nulidades absolutas ou de pleno direito podem ser decretadas de ofício, tanto pelo juiz quanto pela autoridade administrativa.

O ato anulável, ou seja, aquele acometido de uma nulidade relativa possui vício em seus elementos extrínsecos e, portanto, sua decretação deve passar pela verificação da existência ou não de tais elementos. Desta forma, ao contrário das nulidades absolutas, a nulidade relativa não pode ser decretada unilateralmente pela própria Administração, pois depende de aferição de elementos probatórios ${ }^{43}$.

Os atos irregulares são aqueles, cujos vícios são irrelevantes e incapazes de gerar a extinção do ato, como por exemplo, os que contém erros de grafia.

\subsection{Critérios de classificação dos atos administrativos inválidos}

Não existe, no Direito Administrativo, sistematização legal de uma teoria das nulidades, permitindo uma única classificação do ato administrativo inválido.

As entidades federativas - União, Estados-membros, Distrito Federal e Municípios - são dotadas de competência legislativa em matéria administrativa. É cada uma destas entidades políticas que estabelece, observados os princípios constitucionais, os requisitos de validade de seus atos administrativos, quais autoridades são competentes para praticá-los, que finalidade deve ser alcançada, que fatos devem antecedê-los, que forma possuirão, etc. Assim, tem-se que a determinação das causas ensejadoras de nulidade ou anulabilidade, bem como suas consequências e os mecanismos internos de correção, por serem matérias de Direito Administrativo, podem ser estabelecidas de forma diferente por cada uma destas entidades. Daí a impossibilidade de uma sistematização legal, no Direito Brasileiro, de uma teoria das nulidades, aplicável uniformemente a todas as entidades federativas ${ }^{44}$.

\footnotetext{
${ }^{41}$ REALE, Miguel. Revogação e anulamento do ato administrativo. cit., p. 54

${ }^{42}$ Idem, ibidem, p. 55

${ }^{43}$ Idem, ibidem, p. 55

${ }^{44}$ SILVA, Clarissa Sampaio. Limites à invalidação dos atos administrativos. cit., p. 46
} 
Desta forma, vários critérios têm sido propostos, de forma a auxiliar o administrador a encontrar a melhor solução frente aos atos administrativos viciados, quando inexistente legislação específica.

\subsubsection{Critério utilizado pela Lei da Ação Popular}

A Lei federal 4.717 de 20.06.65, que regula a Ação Popular, procurou diferenciar atos nulos de anuláveis.

Nos termos do artigo $2^{\circ}$, da referida Lei, consideram-se nulos os atos lesivos ao patrimônio de entidades públicas que sejam praticados por agentes incompetentes, com vício de forma, ilegalidade do objeto, motivo inexistente e desvio de finalidade.

$\mathrm{O}$ artigo $3^{\circ}$ classifica como anuláveis os atos lesivos ao patrimônio das pessoas de direito público ou privado cujos vícios não sejam os acima apontados.

No entanto, esta classificação pouco contribui para a construção de uma sistematização acerca dos atos administrativos inválidos, uma vez que não diferencia, quanto aos efeitos, atos nulos de anuláveis. Também não estabelece qualquer distinção entre estas espécies de ato, no que diz respeito à legitimação para invocar a nulidade, o prazo ou a possibilidade de convalidação. Conforme afirma Sundfeld ${ }^{45}$, "melhor seria se tivesse usado apenas a expressão atos inválidos”.

Merece destaque, ainda, que esta Lei somente considera lesivos os atos que causem prejuízo ao erário. Porém, existem outros bens e valores igualmente tutelados pelo ordenamento jurídico que podem ser atingidos por um ato administrativo inválido. É o caso da moralidade administrativa, da impessoalidade e da publicidade ${ }^{46}$.

\subsubsection{Critério da possiblidade de convalidação}

Esta classificação, leva em conta a possibilidade de salvar da extinção os efeitos do ato inválido. Assim, os atos inválidos diferenciam-se entre convalidáveis e inconvalidáveis, conforme seja possível, respectivamente, salvar seus efeitos da extinção ou não.

\footnotetext{
${ }^{45}$ SUNDFELD, Carlos Ari. Ato administrativo inválido. cit., p. 44

${ }^{46}$ SILVA, Clarissa Sampaio. Limites à invalidação dos atos administrativos. cit., p. 45
} 
A doutrina diverge quanto aos critérios diferenciadores entre o ato convalidável e inconvalidável.

Para Antônio Carlos Cintra do Amaral $^{47}$ não podem ser convalidados somente os atos que contenham vício quanto ao conteúdo. Os atos produzidos com vício de competência ou formalidade podem ser convalidados, assim como os atos viciados quanto ao pressuposto de fato, que podem ser convalidados por um fato, ou um ato do interessado direto, mas não por um ato do órgão estatal.

Celso Antônio Bandeira de Mello ${ }^{48}$, utiliza o mesmo sistema classificatório, porém adota as expressões atos nulos e inexistentes, para designar aqueles não passíveis de serem convalidados e atos anuláveis, para os que admitem convalidação.

Este também é o pensamento de Edmir Netto de Araújo ${ }^{49}$ que considera anuláveis e, portanto, passíveis de convalidação os atos que a lei assim os declare, os expedidos por agente incompetente, os editados com vício de vontade ou os produzidos com defeito de formalidade. E, nulos, inconvalidáveis, os atos produzidos por agente absolutamente incapaz, e aqueles cujos defeitos decorram da não correspondência entre a declaração e os seus pressupostos e da ilicitude do conteúdo da declaração ${ }^{50}$.

\subsubsection{Critério da legitimidade para provocar a invalidação}

No Direito Civil, os atos inválidos distinguem-se em atos nulos e anuláveis conforme a possibilidade de invalidação, tendo os primeiros ampla possibilidade de invalidação e os segundos uma possibilidade mais restrita ${ }^{51}$.

Os casos de anulabilidade são instituídos em favor da liberdade do sujeito produtor do ato, ou do interesse particular de um terceiro, permitindo que estes possam abrir mão de tais direitos. Por isso, no Direito Civil, quando se tratar de anulabilidade, só quem tem legitimidade para provocá-la é o próprio interessado ${ }^{52}$.

\footnotetext{
${ }^{47}$ AMARAL, Antônio Carlos Cintra do. Teoria do ato administrativo. Belo Horizonte: Fórum, 2008, p. 104

${ }^{48}$ MELLO, Celso Antonio Bandeira. Curso de Direito Administrativo. cit., p.433

49 ARAÚJO. Edmir Netto de. Convalidação do Ato Administrativo. São Paulo: LTr, 1999, p. 128

${ }^{50}$ Idem, ibidem, p. 128

${ }^{51}$ SUNDFELD, Carlos Ari. Ato administrativo inválido. cit., p. 77

${ }^{52}$ Idem, ibidem, p. 77
} 
Em se tratando de casos de nulidade, como o que se tutela é um interesse genérico, que se difunde socialmente, amplia-se a possibilidade de invalidação, estendendo-se a legitimidade para provocá-la ao Ministério Público ${ }^{53}$.

Em relação à invalidade do ato administrativo, o critério diferenciador é diverso.

Aqui, cumpre diferenciar tal legitimação perante o Poder Judiciário e perante a própria Administração produtora do ato.

A legitimação, perante o Judiciário, para provocar a invalidação do ato administrativo pode ser tanto daquele diretamente lesado pelos efeitos do ato, através de meios processuais específicos (Ex: Mandado de Segurança) ou comuns (ações ordinárias), como também de qualquer cidadão, por meio da ação popular.

Um ato administrativo inválido pode lesar somente um direito individual. Neste caso, só tem legitimação para provocar a invalidação, a própria pessoa lesada. No entanto, pode ferir além do direito individual, concomitantemente ou exclusivamente, o patrimônio público, histórico ou a moralidade administrativa. Nestas hipóteses, a legitimação para provocar a invalidação é mais ampla, estendendo-se a qualquer cidadão através da ação popular.

Assim, quando o ato inválido lesar somente um direito individual, a legitimação é somente do indivíduo lesado. Se o bem lesado pelo ato inválido for além do direito individual, atingindo também o patrimônio público, à moralidade administrativa, o patrimônio histórico e cultural, qualquer cidadão poderá pleitear sua invalidação utilizando-se da ação popular.

Portanto, o critério diferenciador, de legitimados para provocar judicialmente a anulação do ato administrativo inválido é a existência de lesão real ou presumida ao patrimônio público.

Enquanto no Direito Civil a amplitude dos legitimados para provocar a invalidação é determinada pela possibilidade ou não de convalidação, no Direito Administrativo, é determinada pela lesão presumida ou real ao patrimônio público na acepção ampla - incluído moralidade administrativa, meio ambiente e patrimônio histórico e cultural.

${ }^{53}$ SUNDFELD, Carlos Ari. Ato administrativo inválido. cit., p. 77 
Este critério é diverso quando se tratar de invalidação pela própria Administração Pública. Por força do disposto no artigo $5^{\circ}$, inciso XXXIV, alínea "a", da Constituição Federal, que estabelece o direito de petição, qualquer um pode peticionar pela invalidação do ato administrativo independentemente da existência de dano ao patrimônio público ou lesão ao direito individual.

\subsubsection{Critério da possibilidade de anulação de ofício}

Carlos Ari Sundfeld ${ }^{54}$ entende não ser possível a anulação de ofício do ato administrativo pelo juiz. Explica que por não haver qualquer previsão em lei federal teríamos três possibilidades: a primeira seria negar a anulação de oficio; a segunda seria admiti-la, por analogia total ao Direito Civil, ou seja, a anulação de ofício somente seria possível, em relação aos atos inconvalidáveis; e a terceira, por analogia parcial ao Direito Civil, ou seja, aplicando-se somente a técnica de invalidação de ofício e não o critério que a restringe (atos inconvalidáveis) seria aceitar tal anulação para qualquer espécie de ato (convalidável ou inconvalidável).

Acrescenta que para criação de uma norma por analogia é preciso a existência de lacuna, ou seja, a ausência de uma norma necessária para o funcionamento do sistema $^{55}$.

No caso da anulação de oficio pelo juiz só poderia reconhecer-se uma lacuna se tal forma de atuação fosse essencial ao controle judicial - o que se sabe não ser, pois é inerente a este controle a atuação provocada -, ou então se constituísse uma regra geral, inerente à atuação jurisdicional que não tivesse sido particularizada para o caso do controle da Administração - o que também não ocorre, visto que mesmo no Direito Civil esta atuação constitui-se como exceção ${ }^{56}$.

Outro argumento apontado pelo autor é que a anulação de oficio pelo juiz exclui o contraditório, impedindo que o julgador conheça os vários ângulos de fatos, direitos e interesses envolvidos, pressuposto de uma decisão ajustada ao Direito e aos

\footnotetext{
${ }^{54}$ SUNDFELD, Carlos Ari. Ato administrativo inválido. cit., p. 78

${ }^{55}$ Idem, ibidem, p. 79

${ }^{56}$ Idem, ibidem, p. 79
} 
fatos. Desta forma, na anulação de ofício há o risco de uma decisão parcial, além de comprometer o princípio da ampla defesa ${ }^{57}$.

Sob argumento de que a invalidação de ofício estaria reservada somente aos atos administrativos com graves vícios, em que houvesse inércia em sua provocação, Sundfeld ${ }^{58}$ contesta dizendo que "mesmo para os atos civis nulos existe prescrição, como admitido pela jurisprudência nacional, o que induz a pensar que a gravidade do vício não é tal que exija a anulação a qualquer custo".

Oswaldo Aranha Bandeira de Mello ${ }^{59}$ entende ser possível a decretação de nulidade de ofício pelo juiz, desde que se trate de inconstitucionalidade ou ilegalidade manifesta, em que se prescinda de discussão e prova a respeito. Afirma que

Isso não se verifica só com referência aos atos da Administração Pública que envolvem crime. Tem ele a possibilidade para declarar de ofício a inconstitucionalidade ou ilegalidade de qualquer ato administrativo, desde que indiscutível e isso se faça necessário para resolver a controvérsia. Invoca-a, então, como alicerce da sua decisão, embora a parte se não tenha apercebido desse vício.

No mesmo sentido se posiciona Celso Antônio Bandeira de Mello ${ }^{60}$, para o qual "no curso de uma lide o juiz pode pronunciar de ofício ou sob provocação do Ministério Público (quando a este caiba intervir no feito) a nulidade de ato gravado deste vício mesmo que o interessado não a argua".

\subsubsection{Critério da incidência de prazo prescricional para anulação}

Têm competência invalidatória do ato administrativo tanto a Administração Pública, em razão do princípio da autotutela, como o Poder Judiciário.

O prazo prescricional para ação judicial anulatória de ato administrativo segue a regra contida no Dec. 200.910, de 6.1.1932, que determina prescreverem em cinco anos todo e qualquer direito contra a Fazenda Pública. Portanto, para anulação procedida

${ }^{57}$ SUNDFELD, Carlos Ari. Ato administrativo inválido. cit., p. 79

${ }^{58}$ Idem, ibidem, p. 80

${ }^{59}$ MELLO, Oswaldo Aranha Bandeira de. Princípios Gerais de Direito Administrativo. cit., p. 658

${ }^{60}$ MELLO, Celso Antonio Bandeira. Curso de Direito Administrativo. cit., p. 443 
pelo Poder Judiciário, tem-se o prazo prescricional de cinco anos, independentemente se se tratar de atos nulos ou anuláveis.

Quando se trata de invalidação administrativa, ou seja, aquela feita pela própria Administração Pública editora do ato, não há legislação específica aplicável a todos os entes federativos. Embora a Lei 9.784/99 tenha disciplinado os prazos para invalidação administrativa, esta só é aplicável à União.

Diante do vácuo legislativo atinente a questão de prazos para invalidação administrativa, diversas soluções são apontadas pela doutrina. Alguns propõem que a Administração Pública possa exercer esta competência a qualquer tempo, ou seja, é imprescritível seu direito de promover a invalidação de seus atos. Outros opinam pela prescritibilidade, divergindo apenas quanto aos prazos. E terceira corrente entende que este direito é prescritível ou imprescritível dependendo da natureza da invalidade.

Neste tópico abordaremos somente a questão da prescritibilidade ou imprescritibilidade de forma geral, não falando dos prazos, o que faremos mais detalhadamente quando adentrarmos ao capítulo da prescrição e decadência para anulação dos atos administrativos.

Hely Lopes Meirelles ${ }^{61}$ está entre os que consideram imprescritíveis o direito do Poder Público invalidar seus próprios atos. Afirma que "para anulação do ato ilegal não se exigem formalidades especiais, nem há prazo determinado para invalidação, salvo quando norma legal o fixar expressamente".

Régis Fernandes de Oliveira ${ }^{62}$ tem o mesmo entendimento, ou seja, "com relação ao próprio Poder Público [...] não há prazo para que se reconheça a invalidação de qualquer ato, pouco importando se nulo ou anulável”.

Dentre os que consideram que independentemente do tipo ou gravidade do vício, sempre há um prazo prescricional para que a Administração Pública promova invalidação podemos citar Oswaldo Aranha Bandeira de Mello ${ }^{63}$, Diógenes Gasparini ${ }^{64}$ e Maria Sylvia Zanella di Pietro ${ }^{65}$. Estes autores priorizando o princípio da segurança

\footnotetext{
${ }^{61}$ MEIRELLES, Hely Lopes. Direito Administrativo Brasileiro. 27. ed., São Paulo: Malheiros, 2002, p.201

${ }^{62}$ OLIVEIRA, Regis Fernandes de. Ato administrativo. 5. ed., São Paulo: Revista dos Tribunais, 2007, p. 152

${ }^{63}$ MELLO, Oswaldo Aranha Bandeira de. Princípios Gerais de Direito Administrativo. cit., p.664

${ }^{64}$ GASPARINI, Diógenes. Direito Administrativo. cit., p.116

${ }^{65}$ DI PIETRO, Maria Sylvia Zanella. “Autotutela: poder de revisão dos atos pela Administração In BDA Boletim de Direito Administrativo - Abr. 1996, p.202
} 
jurídica entendem que a imprescritibilidade poria em risco a necessária estabilidade das relações jurídicas após certo tempo de vigência.

Celso Antônio Bandeira de Mello, Weida Zancaner e Carlos Ari Suldfeld diferenciam, utilizando critérios diversos, as invalidades que são prescritíveis daquelas imprescritíveis.

Para Celso Antônio Bandeira de Mello ${ }^{66}$, tanto os atos nulos como os anuláveis se submetem ao prazo invalidatório de cinco anos. E os atos inexistentes, que para ele são aqueles derivados de conduta criminosa, são imprescritíveis.

Weida Zancaner ${ }^{67}$, com quem concordamos, entende que os atos restritivos de direito dos administrados, quando ilegais, podem ser invalidados a qualquer tempo, o que nos permite concluir serem imprescritíveis. Esta nos parece a posição que mais se coaduna com os princípios informadores do Estado de Direito. No entanto, é importante ressaltar que esta imprescritibilidade só ocorrerá se o ato restritivo de direito de um, não for ao mesmo tempo ampliativo da esfera de direitos de outro indivíduo ou da coletividade. Porque, se isto ocorrer, em decorrência do princípio da segurança jurídica, $a$ priori, não poderá ser invalidado.

Para Sundfeld ${ }^{68}$, somente são imprescritíveis os atos gerais e abstratos. Explica que a prescrição visa proteger situações já constituídas, mas não impede que novas agressões a ordem jurídica sejam intentadas. Assim, cada atuação administrativa embasada em atos gerais e abstratos ilegais provoca uma nova agressão a ordem jurídica. Portanto, a invalidação dos atos concretos (que efetivamente causaram uma violação ao Direito) fundamentados em atos abstratos ilegais se submetem ao prazo prescricional, mas os abstratos e gerais não, porque, nas palavras do autor, "não se pode garantir, sob o argumento da segurança e estabilidade, o surgimento de novas violações à norma jurídica que, ao nascerem, agravarão a própria ideia de segurança e estabilidade”.

${ }^{66}$ MELLO, Celso Antonio Bandeira. Curso de Direito Administrativo. cit., p. 433

${ }^{67}$ ZANCANER, Weida. Da convalidação e da invalidação dos atos administrativos. $3^{\text {a }}$ ed. São Paulo: Malheiros, 2008, p. 78

${ }^{68}$ SUNDFELD, Carlos Ari. Ato administrativo inválido. cit., p. 89-90 


\section{O PRINCÍPIO DA LEGALIDADE NA ADMINISTRAÇÃO PÚBLICA}

\subsection{Introdução}

Princípios são as proposições que contêm as diretrizes gerais de um sistema. São as linhas mestras que orientam o desenvolvimento de uma dada ciência, conferindo-lhe sentido lógico, harmonioso e racional, facilitando sua compreensão.

No Direito, os princípios representam os ideais primeiros de justiça de uma sociedade e por isso funcionam como legitimadores de todo o ordenamento jurídico. Assim, a violação de um princípio é bem mais grave que a transgressão de uma norma, porque implica ofensa a todo o sistema.

Os princípios servem tanto para orientar o legislador na elaboração das normas, como para direcionar o julgador e o administrador na interpretação da lei para sua correta aplicação.

Considerando-se que a Constituição é o texto legal supremo e fundamental de um Estado, os princípios nela contidos expressamente, ou dela extraídos, configuram-se como norteadores fundamentais de todo o ordenamento jurídico. Tais princípios, considerando-se o nível de especificidade, são de diversas categorias. Os mais genéricos, que informam toda a ciência do Direito, são os Princípios Gerais de Direito. Têm-se, ainda, os princípios relativos aos diversos ramos do Direito e, também, os relativos aos diversos institutos de cada ramo do Direito.

Para uma melhor compreensão, o estudo do princípio da legalidade deve ser precedido de uma análise das concepções de lei e de Estado Democrático.

\subsection{Evolução da concepção de Estado}

A concepção do Estado como poder soberano dentro de certo território inicia-se no período do Absolutismo, na Idade Moderna. Anteriormente, na Idade Média havia uma dispersão da autoridade entre inúmeros centros de poder (os reis, a Igreja, os 
senhores feudais, as corporações de ofício) não sendo possível identificar um poder soberano ${ }^{1}$.

Neste período (absolutismo), a relação entre o Estado e seus súditos caracterizava-se pelas seguintes regras: a) o Estado, como criador da ordem jurídica, não se submetia a ela, sob a justificativa de que ninguém pode estar obrigado a obedecer a si próprio; b) os atos do soberano eram inquestionáveis e insuscetíveis de qualquer controle; c) O Estado não era responsável por danos causados aos indivíduos; d) o Estado exercia um poder de polícia sobre os indivíduos. Esse período foi conhecido como Estado-Polícia ${ }^{2}$.

Como consequência, havia uma larga utilização do poder discricionário, gerando incerteza do direito, que variava de acordo com a vontade do Soberano.

A Revolução Francesa, com os ideais liberais, opondo-se ao absolutismo, marcou o início do chamado Estado Liberal. Figura marcante deste período foi Montesquieu que defendia, em sua obra $O$ Espírito das Leis, a separação dos poderes em três - legislativo, executivo e judiciário, com objetivo de evitar a tirania, que concentrava o poder nas mãos de uma só pessoa. Outro pensador de grande influência na época foi J.J. Rosseau, cuja teoria do contrato social pregava a superioridade da lei, de autoria do povo, e não de origem divina, como no absolutismo.

O Estado Liberal tinha como característica principal a subordinação do Estado à lei, com o fortalecimento das garantias individuais frente ao Estado. No entanto, a legalidade aí era meramente formal, de vez que o Estado garantia a observância da lei a todos os indivíduos, mas não garantia o seu sustento. Apenas importava a manifestação do Poder Legislativo, qualquer que fosse ela, desde que adequada à Constituição. O conteúdo das leis era irrelevante ${ }^{3}$. Os direitos e garantias fundamentais assegurados pelas leis não eram efetivados. A lei imperava apenas formalmente, pois materialmente nada acrescentava para a maioria da população, que não detinha condições econômicofinanceiras.

Assim, como reação às imensas desigualdades sociais geradas pelo Estado Liberal, buscando-se uma atuação do Estado na área social, com a efetiva

\footnotetext{
${ }^{1}$ SUNDFELD, Carlos Ari. Fundamentos de Direito Público. 5a . ed. São Paulo: Malheiros, 2010, pp.33-34

${ }^{2}$ Idem, ibidem, p. 33-34

${ }^{3}$ GRAU, Eros Roberto. O Direito posto e o Direito pressuposto. São Paulo: Malheiros, 2005, p. 176
} 
realização dos direitos e garantias assegurados aos indivíduos pelas leis, surge o Estado Social de Direito.

O Estado Social de Direito caracterizava-se por um Estado intervencionista. O Estado intervinha tanto no domínio social como econômico, a fim de garantir os direitos individuais.

Mas, o Estado Social, apesar de atender aos anseios das classes oprimidas economicamente pelo liberalismo, acabou por dar ensejo a alguns regimes políticos totalitários.

Surge, então, o Estado Democrático de Direito, que além de reconhecer e garantir os direitos fundamentais do ser humano, se caracteriza pela efetiva participação democrática do povo, como cidadãos, na elaboração e aplicação do Direito.

A noção de Estado de Direito é vista em dois sentidos: um material e outro formal. Sob o aspecto material tem-se como fundamento do Estado de Direito as ideias de justiça e de segurança jurídica. Em sentido formal, o Estado de Direito caracteriza-se pela conjugação de diversos elementos: a) um sistema de direitos e garantias fundamentais; b) a divisão harmônica dos poderes do Estado, com a existência de um sistema que limite cada poder, o chamado "freios e contrapesos"; c) a legalidade da Administração Pública; d) a proteção da confiança que os cidadãos tem de que o Estado obedecerá e respeitará as leis ${ }^{4}$.

\subsection{Evolução do princípio da legalidade}

O princípio da legalidade está intimamente relacionado com o Estado de Direito, de forma que as modificações ocorridas na noção de Estado de Direito, foram acompanhadas das alterações no sentido de legalidade.

No início do Estado Liberal, a lei funcionava como limitadora ao poder do Estado, de forma que este intervisse o mínimo possível na esfera de direitos individuais dos cidadãos. A legalidade tinha sentido de vinculação negativa, ou seja, a Administração

${ }^{4}$ SILVA, Almiro do Couto e. "Princípios da legalidade da administração pública e da segurança jurídica no estado de direito contemporâneo". In Revista de Direito Público. São Paulo, vol. 84, p. 46-63, out-dez/1987, p.46 
podia fazer tudo o que a lei não proibisse, gerando como consequência um vasto campo para atuação discricionária, livre de controle ${ }^{5}$.

Já no Estado Social, a fim de se reduzirem as desigualdades sociais ocasionadas pelo liberalismo, tornando necessária uma maior intervenção do Estado no domínio social e econômico, o principio da legalidade passou a ter o sentido de vinculação positiva, ou seja, o Estado deveria agir quando a lei assim determinasse ${ }^{6}$. Neste período, a lei era fundamento para o Estado tornar-se o grande prestador de serviços, com o objetivo de dirimir os grandes conflitos e diferenças sociais existentes, atuando como empresário em áreas pouco ou nada exploradas pela iniciativa privada. Porém, a legalidade formal ainda era utilizada pelos regimes totalitários e ditatoriais, que buscavam na lei a sua legitimidade, após utilizarem-se da força.

Com o advento do Estado Democrático de Direito, a lei passou a ter o sentido material, uma vez que passou a ser a expressão efetiva da vontade popular, que indiretamente participa do seu processo de elaboração.

A submissão do Estado a uma ordem jurídica é a base do Estado de Direito.

O ordenamento jurídico é concebido como um sistema escalonado e hierarquizado, em que a norma de escalão inferior tem seu fundamento na norma de escalão superior. Pode ser representado graficamente como uma pirâmide, em cujo topo encontra-se a Constituição. Desta forma, a Constituição é o fundamento de validade de todas as normas do ordenamento jurídico.

A Administração Pública encontra-se inserida dentro do ordenamento jurídico. Assim, sua atuação só se justifica se concretizadora de normas jurídicas precedentes $^{7}$.

Reforçando tal assertiva, a Constituição Federal de 1988, inovou ao contemplar os princípios a que deve se submeter a Administração Pública, e dentre eles constou expressamente o princípio da legalidade.

${ }^{5}$ DI PIETRO, Maria Sylvia Zanella. "Da Constitucionalização do Direito Administrativo: Reflexos sobre o Principio da legalidade e a Discricionariedade”. In: DI PIETRO, Maria Sylvia Zanella, e RIBEIRO, Carlos Vinícius Alves. Supremacia do interesse público e outros temas relevantes do direito administrativo. São Paulo: Atlas, 2010, p. 177

${ }^{6}$ Idem, ibidem, p. 178

${ }^{7}$ BINENBOJM, Gustavo. "O sentido da vinculação administrativa à juridicidade no direito brasileiro". In: ARAGÃO, Alexandre Santos de, e MARQUES NETO, Floriano de Azevedo. Direito Administrativo e seus novos paradigmas. Belo Horizonte: Fórum, 2008, p. 158 
Considerando que a submissão do Estado, e consequentemente da Administração Pública ao ordenamento jurídico é um dos elementos fundamentais do Estado de Direito, o Constituinte de 1988 ao determinar expressamente no artigo 37 da Carta Magna a observância obrigatória pela Administração Pública do princípio da legalidade, buscou dar ao mesmo importância ímpar.

É certo que outros princípios de Direito Administrativo também adquiriram status constitucional. Alguns constam de forma expressa, como é o caso dos princípios da impessoalidade, moralidade, publicidade e eficiência, que figuram juntamente com o princípio da legalidade no artigo 37 da Constituição Federal.

Hoje, fala-se em constitucionalização do Direito Administrativo. Este fenômeno se deve principalmente à incidência em seu domínio dos princípios constitucionais, não só específicos, mas os de caráter geral, como da dignidade humana. Operou-se, consequentemente, uma modificação da qualidade das relações entre Administração e administrado, reformulando-se paradigmas tradicionais. ${ }^{8}$

Por força dessa constitucionalização do Direito Administrativo, o princípio da legalidade, no âmbito da Administração Pública, transformou-se num verdadeiro principio da juridicidade ou da legitimidade, a significar vinculação do administrador à Constituição, e não apenas à lei ordinária.

A legalidade, em sentido estrito, difere da legitimidade, e nem sempre estes atributos estão presentes num mesmo ato administrativo. A legalidade, em sentido estrito, diz com a estrita adequação do ato à lei formal, enquanto a legitimidade corresponde à adequação desse mesmo ato administrativo à totalidade das regras e princípios integrantes do sistema. Um ato editado em estrita observância da lei, que posteriormente é declarada inconstitucional, por afrontar algum princípio constitucional, pode ser citado como exemplo de ato legal e ilegítimo?.

Eros $\mathrm{Grau}^{10}$ afirma que a legalidade, com o advento do Estado de Direito material (Estado Democrático de Direito), foi desmitificada, desvinculando-se do princípio da separação dos poderes, no sentido de que "a legalidade será observada ainda quando a função normativa seja desenvolvida não apenas pelo Poder Legislativo”. Significa dizer

\footnotetext{
${ }^{8}$ BARROSO, Luís Roberto. A constitucionalização do direito e suas repercussões no âmbito administrativo. In: ARAGÃO, Alexandre Santos de, e MARQUES NETO, Floriano de Azevedo. Direito Administrativo e seus novos paradigmas. Belo Horizonte: Fórum, 2008, p. 49

${ }^{9}$ MOTTA, João Francisco da. Invalidação dos atos administrativos. Belo Horizonte: Del Rey, 2010, p.13

${ }^{10}$ GRAU, Eros Roberto. O Direito posto e o Direito pressuposto. cit., p. 180
} 
que o princípio da legalidade não se refere apenas à lei em sentido formal, mas sim ao ordenamento jurídico como um todo, incluindo todas as fontes normativas, inclusive os regulamentos que a própria Administração Pública produzir.

Nesse mesmo sentido, afirma Juarez Freitas ${ }^{11}$ que "a subordinação da Administração Pública não é apenas à lei. Deve haver o respeito à legalidade sim, mas encartada no plexo de características e ponderações que a qualifiquem como razoável”.

Sob este aspecto, é possível afirmar que o princípio da legalidade abarca todos os demais. A atuação da Administração Pública é legítima, quando em consonância com a lei e com os demais princípios constitucionais.

Mesmo que em algumas situações seja necessário ao administrador, diante do caso concreto, fazer uma ponderação entre princípios que aparentemente estão em tensão, ainda assim estará dentro da legalidade (em sentido amplo). Ao escolher um ou outro princípio aplicável ao caso, estará agindo dentro dos parâmetros legais.

José Afonso da Silva ${ }^{12}$, discorrendo sobre o princípio da legalidade, afirma:

O princípio da legalidade é nota essencial do Estado de Direito. É, também, por conseguinte, um princípio basilar do Estado Democrático de Direito, como vimos, porquanto é da essência do seu conceito subordinarse à Constituição e fundar-se na legalidade democrática. Sujeita-se ao império da lei, mas da lei que realize o princípio da igualdade e da justiça não pela sua generalidade, mas pela busca da igualização das condições dos socialmente desiguais.

Percebe-se, aí, na referência a uma lei que realize o princípio da igualdade e da justiça, de uma lei não somente no aspecto formal, mas também no aspecto material, aquela amplitude do princípio da legalidade administrativa, resultado da submissão da Administração Pública à Constituição e aos princípios que dela resultam. Embora, na seqüência do texto, o jurista se afaste dessa concepção ao falar numa lei

\footnotetext{
${ }^{11}$ FREITAS, Juarez. O controle dos atos administrativos e os principios fundamentais. 4. ed., São Paulo: Malheiros Editores, 2009, p. 60-61

${ }^{12}$ SILVA, José Afonso da. Curso de Direito Constitucional Positivo. 25a ed. São Paulo: Malheiros, 2005, p. 420
} 
entendida como expressão da vontade geral, que só se materializa num regime de divisão de poderes em que ela seja o ato formalmente criado pelos órgãos de representação popular, de acordo com o processo legislativo estabelecido na Constituição.

É nesse sentido que se deve entender a assertiva de que o Estado, ou o Poder Público, ou os administradores não podem exigir qualquer ação, nem impor qualquer abstenção, senão em virtude de $l \mathrm{ei}^{13}$.

Desta forma, o princípio da legalidade, relativamente à Administração Pública, não pode ser visto somente no seu aspecto estrito, de adequação exclusivamente à lei, considerada esta como o preceito geral elaborado pelo Poder competente.

Há de ter um sentido amplo, em que aquela submissão à lei leve em conta não somente a lei formal, mas também os princípios constitucionais expressos ou implícitos.

Porque em determinadas situações, como veremos mais adiante, outros princípios, como o da segurança jurídica, por exemplo, hão de ser tidos como integrantes da legalidade, para justificar a manutenção de situações jurídicas que se mostram afastadas da lei em seu sentido estrito, formal.

\subsection{Consequências da atual concepção do princípio da legalidade.}

A evolução pela qual passou o princípio da legalidade, no sentido de sua transformação de legalidade estrita em juridicidade - submissão da Administração a todo ordenamento jurídico, inclusive e principalmente à Constituição -, trouxe como principal consequência a possibilidade da atuação administrativa encontrar fundamento não somente na lei (em sentido estrito) como também diretamente na Constituição.

Assim, é possível explicar a atuação do administrador diante da inexistência de lei dispondo explicitamente sobre determinada situação, buscando fundamento nos princípios constitucionais.

${ }^{13}$ SILVA, José Afonso da. Curso de Direito Constitucional Positivo. cit., p. 420 
$\mathrm{Na}$ inexistência de lei que autorize uma certa atuação da Administração Pública, poderá esta buscar o fundamento de validade diretamente na Constituição Federal e ainda assim, estará cumprindo o princípio da legalidade (ou juridicidade).

Nesse sentido, se manifestou o Ministro Luiz Fux, no Ag. Reg. RE 636.661 - Maranhão, afirmando que não procede a alegação do Estado justificando o não pagamento a servidor de verbas referentes a férias não gozadas, em razão da inexistência de lei autorizadora. De acordo com o Ministro:

o fundamento de ofensa ao princípio da legalidade não encontra guarida, pois o estado recorrido não pode se valer do argumento de ausência de lei prevendo a conversão de férias não gozadas em pecúnia para eximir-se do pagamento do direito laboral constitucionalmente assegurado, sobretudo quando a fruição deste restou inviabilizada por estar o servidor em exercício de função pública indeclinável, a de juiz corregedor do Tribunal da respectiva unidade da federação. Essa proibição esta encerrada no princípio geral de direito da vedação ao enriquecimento sem causa, aplicável inclusive à Administração Pública, conforme bem acentuado nos precedentes supracitados ${ }^{14}$.

Neste caso, o pagamento das férias não gozadas, embora inexistente lei específica dispondo a respeito, encontra fundamento em princípio geral de direito que veda o enriquecimento sem causa de uma parte em detrimento da outra, aplicável também à Administração Pública.

Pode-se, ainda, imaginar a seguinte situação hipotética: O Estatuto do servidor público de determinado município concede aos seus servidores o direito à licença em descanso por três meses a cada cinco anos de efetivo exercício. Porém, nada fala sobre a possibilidade da conversão em pecúnia por necessidade do serviço ou interesse público. Desta forma, ao considerarmos um exíguo corpo clínico de um determinado hospital público, em que a ausência de um de seus médicos traria sérios prejuízos no atendimento da população em razão da alta demanda de atendimentos, o princípio da legalidade estrita, não deixaria outra alternativa à autoridade administrativa senão a de conceder a licença ao médico.

${ }^{14}$ STF, Ag. Reg. RE 636.661- MA, 1 ${ }^{\text {a }}$ Turma, Ministro Luiz Fux, DJ: 16/10/2012 
Mas, considerando-se a legalidade em sentido amplo, poderia a autoridade administrativa negar a licença e convertê-la em pecúnia, fundamentada diretamente no princípio constitucional da supremacia do interesse público sobre o privado - para a negativa da licença, uma vez que o interesse público na permanência do médico no serviço deve prevalecer sobre seu interesse particular do gozo da licença - e no dispositivo constitucional que trata da responsabilidade objetiva do Estado - fundamento para a conversão da licença em pecúnia - consistente em seu dever de indenizar os prejuízos que causar a terceiros, seja decorrente de ato lícito ou ilícito (art. 37, $\S 6^{\circ}$, Constituição Federal).

Outra consequência é a possibilidade de atuação administrativa válida de forma contrária a lei em sentido estrito, quando esta for inconstitucional, ou na hipótese de sua constitucionalidade, for verificada sua discordância, diante do caso concreto, com outros princípios que devam incidir com maior força, numa operação de ponderação ${ }^{15}$.

Em se tratando de lei que afronte a Constituição, deverá haver a declaração de sua inconstitucionalidade. A Administração Pública, em todas as esferas da federação está obrigada a zelar pela guarda da Constituição (art. 23, I, Constituição Federal). Por isso, embora não tenha competência para declarar a inconstitucionalidade, não pode dar cumprimento a uma lei que autoriza uma atuação com nítida afronta a Constituição.

É importante ressaltar que a autoridade administrativa que negar cumprimento a lei que considere inconstitucional responderá pelas consequências de seu descumprimento. Assim, se posteriormente, a lei for declarada pelo judiciário em conformidade com a Constituição, o administrador arcará com a responsabilidade de ter contrariado o princípio da legalidade.

Ao contrário, haverá o saneamento (ou convalidação tácita) de um ato administrativo, editado em desconformidade com uma lei, caso esta lei seja declarada posteriormente inconstitucional.

Outra consequência do princípio da legalidade considerada em sentido amplo é a justificação da convalidação ou da manutenção do ato administrativo inválido, que diante do caso concreto, numa ponderação entre o princípio da legalidade estrita e o da

${ }^{15}$ BINENBOJM, Gustavo. "O sentido da vinculação administrativa à juridicidade no direito brasileiro". Op. cit., p. 189 
segurança jurídica (outro pilar do Estado de Direito), determine a prevalência dos princípios da segurança jurídica e da boa-fé dos administrados. Assim, embora o ato administrativo seja contrário a lei em sentido estrito, a sua manutenção atende a outro princípio constitucional: o da segurança jurídica ${ }^{16}$.

Assim, percebe-se que a evolução pela qual passou o principio da legalidade acaba por influenciar diretamente a atuação administrativa, no sentido de que, ao atuar, a autoridade administrativa, em especial no exercício do Poder discricionário deve levar em conta não somente a lei em sentido estrito, mas sim todos os princípios constitucionais, a fim de escolher a opção mais acordada com todo o sistema jurídico, mesmo que o caminho escolhido constitua afronta a lei em sentido estrito.

${ }^{16}$ Idem, ibidem, p. 189 


\section{O PRINCÍPIO DA SEGURANÇA JURÍDICA NA ADMINISTRAÇÃO PÚBLICA}

O Direito corresponde a um conjunto de normas que se destinam a orientar a conduta das pessoas num certo sentido, de forma a permitir uma convivência social pacífica. Para que as pessoas possam se orientar é necessário que saibam de antemão a consequência imputável a seus atos. E, é a ordem jurídica que confere tal previsibilidade e segurança aos sujeitos de Direito permitindo uma certa segurança em relação ao futuro ${ }^{1}$.

A ordem e a segurança andam juntas de forma que uma não existe sem a outra e ambas conferem estabilidade às relações entre os indivíduos.

Conforme afirma Celso Antônio Bandeira de Mello²,

o Direito é per definitionem um esquema de ordem, e por isso se fala em ordenação jurídica, em ordenamento jurídico. A surpresa, o imprevisível, a instabilidade, são, precisamente, noções antitéticas ao Direito, que com elas não poderia conviver, nem seria exequível, tanto mais porque tem como função elimina-las.

É de se lembrar, ainda, que sendo o Direito uma disciplina da conduta humana, o mesmo deve se compatibilizar com o que há de básico, de fundamental no ser humano: o desejo de segurança, de estabilidade.

Portanto, pode-se afirmar que o princípio da segurança jurídica é, sem dúvida, o maior de todos os princípios informadores do Direito porque se encontra em sua base, a partir da qual se irradiam os demais princípios.

Tamanha é a importância da segurança jurídica, que a própria Constituição Federal reconhece a necessidade de estabilização das relações entre indivíduos, mesmo quando estas relações tiverem se constituído em afronta direta à Carta

\footnotetext{
${ }^{1}$ MELLO, Celso Antonio Bandeira de. Grandes temas de Direito Administrativo. São Paulo: Malheiros, 2010, p. 11-12

${ }^{2}$ Idem, ibidem, p. 168
} 
Magna. Disto é exemplo o previsto no art. 19, da $\mathrm{ADCT}^{3}$, que conferiu estabilidade aos servidores públicos, que na data da promulgação da Constituição contavam com cinco anos de serviço público, mesmo que seu ingresso tenha se dado sem concurso público contrariando o exigido pela Constituição anterior e a atual; o art. 17, $\S 2^{\circ}$, da $\mathrm{ADCT}^{4}$, que permitiu a continuidade do acúmulo de cargos ou empregos de profissionais na área da saúde, embora a Constituição de 1969 e a Constituição de 1988, antes da EC 19/98, vedasse tal acúmulo.

Conforme nos ensina Almiro Couto e Silva ${ }^{5}$, o princípio da segurança jurídica engloba um aspecto objetivo e um subjetivo. Sob a ótica objetiva, impede a retroatividade dos atos Estatais, sejam eles administrativos ou legislativos, protegendo o direito adquirido, o ato jurídico perfeito e a coisa julgada. Tem, portanto, conexão com elementos objetivos da ordem jurídica, visando conferir estabilidade e segurança na aplicação do direito.

No aspecto subjetivo, diz respeito à previsibilidade dos indivíduos em relação aos efeitos jurídicos dos atos. Protege a confiança das pessoas nos atos e condutas do Estado.

O princípio da proteção à confiança é consequência da presunção de legitimidade dos atos administrativos e "leva em conta a boa-fé do cidadão, que acredita e espera que os atos praticados pelo poder público sejam lícitos e, nessa qualidade, serão mantidos e respeitados pela própria Administração e por terceiros" ${ }^{\prime 6}$.

De acordo com J.J. Gomes Canotilho ${ }^{7}$ :

\footnotetext{
${ }^{3}$ Art. 19, ADCT - "Os servidores públicos civis da União, dos Estados, do Distrito Federal e dos Municípios, da administração direta, autárquica e das fundações públicas, em exercício na data da promulgação da Constituição, há pelo menos cinco anos continuados, e que não tenham sido admitidos na forma regulada no Art. 37, da Constituição, são considerados estáveis no serviço publico".

${ }^{4}$ Art. $17, \S 2^{\circ}$, ADCT - "É assegurado o exercício cumulativo de dois cargos ou empregos privativos de profissionais de saúde que estejam sendo exercidos na administração pública direta ou indireta".

${ }^{5}$ SILVA, Almiro do Couto e. "O princípio da segurança jurídica (proteção à confiança) no direito público brasileiro e o direito da Administração Pública de anular seus próprios atos administrativos: o prazo decadencial do art. 54 da Lei do Processo Administrativo da União (Lei 9.784/99)". Revista Eletrônica de Direito do Estado, Salvador, Instituto de Direito Público da Bahia, n. 2, abril/maio/junho, 2005. Disponível na Internet: [http://www.direitodoestado.com.br]. Acesso em 12 de março de 2013.

${ }^{6}$ DI PIETRO, Maria Sylvia Zanella. "O princípio da proteção à confiança, da segurança jurídica e da boa-fé na anulação do ato administrativo". Fórum Administrativo - Direito Público - FA, Belo Horizonte, ano 9, n. 100. p. $155-166$, jun. 2009 , p. 158

${ }^{7}$ CANOTILHO, José Joaquim Gomes. Direito Constitucional e Teoria da Constituição. $3^{\mathrm{a}}$ ed. Coimbra: Almedina, 1999, p. 252
} 
o homem necessita de segurança para conduzir, planificar e conformar autônoma e responsavelmente a sua vida. Por isso, desde cedo se consideravam os princípios da segurança jurídica e da proteção à confiança como elementos constitutivos do Estado de direito. Estes dois princípios - segurança jurídica e proteção à confiança - andam estreitamente associados, a ponto de alguns autores considerarem o principio da proteção da confiança como um subprincípio ou como uma dimensão especifica da segurança jurídica. Em geral, considera-se que a segurança jurídica está conexionada com elementos objetivos da ordem jurídica - garantia de estabilidade jurídica, segurança de orientação e realização do direito - enquanto a proteção da confiança se prende mais com as componentes subjetivas da segurança, designadamente a calculabilidade e previsibilidade dos indivíduos em relação aos efeitos jurídicos dos actos dos poderes públicos.

A doutrina estrangeira, em especial a alemã, estabelece distinções. A segurança jurídica é utilizada para designar a natureza objetiva do conceito, enquanto que a proteção à confiança ou proteção à confiança legítima é utilizada para designar o princípio sob o aspecto subjetivo.

O principio da proteção a confiança desenvolveu-se e difundiu-se por todo o mundo a partir do julgamento pelo Tribunal Alemão do caso conhecido como da "viúva de Berlim", em que se acabou reconhecendo a prevalência do princípio da confiança legítima - aspecto subjetivo da segurança jurídica - sobre o da legalidade. $\mathrm{Na}$ hipótese, a Administração impôs como condição à concessão de pensão à viúva de funcionário que ela se transferisse de Berlim Oriental para Berlim Ocidental, o que foi feito. Após um ano de recebimento do benefício, foi ele cancelado ao argumento que teria sido concedido ilegalmente, por vício de competência. O Tribunal Alemão, considerando a confiança depositada pela viúva nos provimentos administrativos, que a levou inclusive a mudar de residência, determinou a continuidade do pagamento. Isso representou a prevalência do princípio da confiança legítima sobre o da legalidade estrita.

Sob a ótica objetiva, a segurança jurídica já se encontra há muito tempo consagrada no nosso ordenamento jurídico. É o caso, por exemplo, do art. 146 do Código 
Tributário Nacional (Lei 5.172, de 25.10.1966) ${ }^{8}$, que determina somente ser aplicável a mudança de orientação da autoridade administrativa no exercício do lançamento em decorrência de fato gerador superveniente. Pode-se citar, ainda, a proteção ao direito adquirido, ao ato jurídico perfeito e à coisa julgada.

Já o princípio da proteção à confiança, aspecto subjetivo da segurança jurídica, somente passou a ser referido pela legislação brasileira, mesmo que de forma implícita, a partir da edição das Leis 9.784 de 29 de janeiro de 1999 (arts. $2^{\circ}$. e 54) ${ }^{9}, 9.868$ de 10 de novembro de 1999 (art. 27) ${ }^{10}$ e 9.882, de 03 de dezembro de 1999 (art. 11) ${ }^{11}$, que regulamentam, respectivamente, o processo administrativo federal, a ação declaratória de constitucionalidade, ação direta de inconstitucionalidade e a arguição de descumprimento de preceito fundamental. Estes dispositivos reconhecem a segurança jurídica como princípio a ser observado pela Administração Pública, justificador da permanência no mundo jurídico de atos administrativos inválidos, como também lhe confere valor constitucional a ser ponderado, em determinadas circunstancias, com o princípio da supremacia da Constituição e da nulidade ex tunc da lei inconstitucional ${ }^{12}$.

A proteção à confiança relaciona-se à boa-fé.

A boa-fé, conforme definições normalmente encontradas nos dicionários significa correção de procedimento, lealdade, franqueza, sinceridade. Diz respeito à conduta do agente. Este é o aspecto objetivo da boa-fé. Mas, também há o aspecto

${ }^{8}$ Art. 146, CTN - "A modificação introduzida, de ofício ou em conseqüência de decisão administrativa ou judicial, nos critérios jurídicos adotados pela autoridade administrativa no exercício do lançamento somente pode ser efetivada, em relação a um mesmo sujeito passivo, quanto a fato gerador ocorrido posteriormente à sua introdução.

${ }^{9}$ Lei 9.784/99 - “Art. 2º A Administração Pública obedecerá, dentre outros, aos princípios da legalidade, finalidade, motivação, razoabilidade, proporcionalidade, moralidade, ampla defesa, contraditório, segurança jurídica, interesse público e eficiência”.

Art. 54. "O direito da Administração de anular os atos administrativos de que decorram efeitos favoráveis para os destinatários decai em cinco anos, contados da data em que foram praticados, salvo comprovada má-fé".

${ }^{10}$ Lei 9.868/99 - Art. 27. "Ao declarar a inconstitucionalidade de lei ou ato normativo, e tendo em vista razões de segurança jurídica ou de excepcional interesse social, poderá o Supremo Tribunal Federal, por maioria de dois terços de seus membros, restringir os efeitos daquela declaração ou decidir que ela só tenha eficácia a partir de seu trânsito em julgado ou de outro momento que venha a ser fixado".

${ }^{11}$ Lei 9882/99 - Art. 11. "Ao declarar a inconstitucionalidade de lei ou ato normativo, no processo de argüição de descumprimento de preceito fundamental, e tendo em vista razões de segurança jurídica ou de excepcional interesse social, poderá o Supremo Tribunal Federal, por maioria de dois terços de seus membros, restringir os efeitos daquela declaração ou decidir que ela só tenha eficácia a partir de seu trânsito em julgado ou de outro momento que venha a ser fixado".

${ }^{12}$ SILVA, Almiro do Couto e. "O princípio da segurança jurídica (proteção à confiança) no direito público brasileiro e o direito da Administração Pública de anular seus próprios atos administrativos: o prazo decadencial do art. 54 da Lei do Processo Administrativo da União (Lei 9.784/99)". Revista Eletrônica de Direito do Estado, Salvador, Instituto de Direito Público da Bahia, n. 2, abril/maio/junho, 2005. Disponível em: [http://www.direitodoestado.com.br]. Acesso em 12 de março de 2013 
subjetivo, que equivale à crença do indivíduo de que está agindo corretamente. Neste caso, não importa sua ação. Se o agente, por desconhecer todos os elementos de uma determinada situação, atua de forma equivocada, mas acreditando que sua conduta está correta, diz-se que sua ação foi pautada pela boa-fé no sentido subjetivo.

No Brasil, o principio da boa-fé tem sido aplicado, mesmo antes de ser positivado. No direito privado, aparece expressamente no Código de Defesa do Consumidor (Lei 8.078/90) ${ }^{13}$, que exige a observância da boa-fé na formação e execução do contrato. O Código Civil de 1916 não mencionava referido principio, o que só foi feito no Código Civil de 2002, que se referiu à boa-fé nos artigos 113,187 e $422^{14}$.

No Direito Administrativo, o primeiro diploma legal a mencioná-lo foi a lei que regulamenta o processo administrativo federal (Lei 9.784/99). No art. $2^{\circ}$, $\S$ único, IV, determina à Administração Pública que atue nos processos administrativos informada por "padrões éticos de probidade, decoro e boa-fé". E, no art. $4^{\circ}, \S 2^{\circ}$, impõe ao administrado que proceda perante à Administração com "lealdade, urbanidade e boa-fé". Em ambos dispositivos, percebe-se a referencia ao aspecto objetivo da boa-fé.

$\mathrm{Na}$ Constituição não há disposição expressa, mas pode ser extraído seu sentido como decorrência de outros princípios constitucionais, principalmente o da moralidade e da probidade administrativa.

Há uma interligação entre os princípios da segurança jurídica, da boa-fé e da proteção à confiança.

\footnotetext{
${ }^{13}$ Lei 8.078/90 - Art. $4^{\circ}$ - "A Política Nacional das Relações de Consumo tem por objetivo o atendimento das necessidades dos consumidores, o respeito à sua dignidade, saúde e segurança, a proteção de seus interesses econômicos, a melhoria da sua qualidade de vida, bem como a transparência e harmonia das relações de consumo, atendidos os seguintes princípios:

$\ldots$

III - harmonização dos interesses dos participantes das relações de consumo e compatibilização da proteção do consumidor com a necessidade de desenvolvimento econômico e tecnológico, de modo a viabilizar os princípios nos quais se funda a ordem econômica, sempre com base na boa-fé e equilíbrio nas relações entre consumidores e fornecedores;"

${ }^{14}$ Lei 10.406/2002 (Código Civil) - Art. 113. "Os negócios jurídicos devem ser interpretados conforme a boa-fé e os usos do lugar de sua celebração".

Art. 187. "Também comete ato ilícito o titular de um direito que, ao exercê-lo, excede manifestamente os limites impostos pelo seu fim econômico ou social, pela boa-fé ou pelos bons costumes".

Art. 422. "Os contratantes são obrigados a guardar, assim na conclusão do contrato, como em sua execução, os princípios de probidade e boa-fé".
} 
Pode-se dizer que a segurança jurídica engloba a proteção à confiança, uma vez que este é o aspecto subjetivo da segurança jurídica e diz respeito à previsibilidade dos indivíduos em relação aos efeitos jurídicos dos atos.

E o princípio da proteção à confiança protege a boa-fé dos administrados, que acreditam na lisura da conduta administrativa. Portanto, o que se protege é a boa-fé dos cidadãos no sentido subjetivo. É sob este fundamento que se veda a anulação de atos administrativos que tenham ampliado a esfera de direitos dos administrados.

\subsection{Da aplicação dos princípios da segurança jurídica, proteção à} confiança e boa-fé na Administração Pública

Os princípios da segurança jurídica, da boa-fé e da confiança legítima são da própria essência do Direito. Portanto, enquadram-se entre os chamados princípios gerais de Direito, que, de acordo com Celso Antônio Bandeira de Mello ${ }^{15}$, "são vetores normativos subjacentes ao sistema jurídico-positivo". Por esta razão têm aplicação em todos os ramos de Direito, e em todas as esferas de atuação do Estado: Legislativa, Administrativa e Judiciária.

No âmbito do Legislativo, encontramos a irretroatividade das leis, a proteção constitucional ao direito adquirido, ao ato jurídico perfeito, e à coisa julgada, com o objetivo de proteger os cidadãos contra eventuais alterações à situação jurídica dos administrados por força de leis.

No Judiciário, o principio da segurança jurídica é amplamente aplicado. Embora as decisões jurisdicionais provoquem modificações em situações jurídicas constituídas anteriormente, não há afronta aos aludidos princípios (segurança jurídica, proteção à confiança e boa-fé), uma vez que é da essência da atividade jurisdicional a solução de conflitos, que envolvem situações ocorridas anteriormente. As decisões proferidas, assim, não surpreendem ninguém, não se podendo falar em insegurança jurídica. É óbvio que as decisões judiciais devem respeitar a coisa julgada, não podendo, também, como regra, aplicar legislação que passou a viger após o fato que constitui o cerne do conflito. Em assim fazendo, está observando o princípio da segurança jurídica.

\footnotetext{
${ }^{15}$ MELLO, Celso Antonio Bandeira de. Grandes temas de Direito Administrativo, cit., p. 179
} 
Pode-se objetar relativamente a decisões embasadas em orientação jurisprudencial posteriormente alterada.

Mas nestas hipóteses, quando verificado in concreto que a aplicação de tal mudança de orientação poderia abalar a segurança jurídica, o Supremo Tribunal Federal tem procurado adaptar os efeitos da decisão à peculiaridade da situação, respeitando os efeitos passados, e limitando-se ao desencadeamento de efeitos prospectivos ou modulados.

No RE 637485, de relatoria do Ministro Gilmar Mendes, ficou reconhecido que "as decisões do Tribunal Superior Eleitoral que, no curso do pleito eleitoral ou logo após o seu encerramento, impliquem mudança de jurisprudência, não têm aplicabilidade imediata ao caso concreto e somente terão eficácia sobre outros casos no pleito eleitoral posterior”. O caso versou sobre a segunda reeleição para o cargo de prefeito. À época da candidatura à segunda reeleição, a jurisprudência do Superior Tribunal Eleitoral era firme ao considerar que esta quando ocorria em município diverso não afrontava o disposto no art. $14, \S 5^{\circ}$, da Constituição Federal. Porém, já no período da diplomação do prefeito reeleito, o TSE alterou sua jurisprudência e passou a considerar tal hipótese como vedada pelo art. $14, \S 5^{\circ}$, da Constituição. A candidatura foi impugnada e o TRE manteve-a com base no anterior entendimento do TSE. Porém, ao julgar o recurso especial eleitoral, o TSE aplicou seu novo entendimento, reformando a decisão anterior. Em sede de Recurso Extraordinário, o STF, além de reconhecer a correta interpretação do TSE quanto à vedação absoluta à segunda reeleição, determinou que por razões de segurança jurídica, tal entendimento, embora correto, não poderia ser aplicado ao caso concreto, uma vez que a mudança de interpretação ocorreu no curso do pleito eleitoral ${ }^{16}$.

No mesmo sentido, os acórdãos proferidos no MS 26603/DF, e no MS 26604/DF, relatorias do Ministro Celso de Mello e da Ministra Cármen Lúcia, respectivamente, em que se discutiu a validade de ato do Presidente do Legislativo, que indeferiu pedido do impetrante para declarar a vacância do cargo de deputado, em razão de o mesmo ter se desligado do partido pelo qual se elegera. Também aqui, apesar do reconhecimento de que a infidelidade partidária traz como consequência a perda do cargo, o acórdão determinou que, em virtude de à época dos fatos (mudança de partido), o entendimento jurisprudencial tanto do TSE como do próprio STF era de que a titularidade do mandato era do candidato e não do partido político, pelo que o desligamento do

${ }^{16}$ STF, RE 637485/RJ, Min. Gilmar Mendes, Tribunal Pleno, DJ: 01/08/2012 
parlamentar da agremiação pela qual se elegera não acarretava a perda do cargo, este novo entendimento somente deveria ser aplicado a fatos que ocorressem posteriormente à data da resposta à consulta ao TSE, considerada como marco temporal desta alteração jurisprudencial $^{17}$.

No RE 442683-8/RS, que teve origem numa ação civil pública, objetivando a anulação de ato de ascensão funcional de servidores do TRT, da $4^{\mathrm{a}}$ região, sob o fundamento de que esta forma de provimento vertical, embora autorizada pela Lei 8.112/90, constituía afronta à Constituição Federal, no que diz respeito à obrigatoriedade geral de realização de concurso público, foi reconhecida a ilegalidade do ato; porém, foram preservados os seus efeitos, por razões de segurança jurídica e de interesse público. O fundamento da decisão foi que na época dos fatos o entendimento a respeito do tema não era pacífico e, somente em momento posterior, o Supremo Tribunal Federal suspendeu, com efeito ex nunc, a eficácia dos dispositivos legais autorizadores daquela prática ${ }^{18}$.

Verifica-se, ainda, a observância do principio da segurança jurídica em decisões do Supremo Tribunal Federal que, fora das hipóteses de controle concentrado em que há expressa previsão legal de modulação de efeitos da decisão -, no exercício do controle difuso da constitucionalidade, tem aplicado efeitos prospectivos à declaração de inconstitucionalidade incidental.

Disso é exemplo o voto do Ministro Maurício Correa, proferido no RE 197917, originário de ação civil pública, que objetivava a redução do número de vereadores de Mira Estrela, fixado por Lei municipal, acima do permitido pela CF. Após reconhecer a inconstitucionalidade de referida Lei, assim sintetizou a justificativa para aplicação de efeitos prospectivos à declaração incidental de inconstitucionalidade:

É verdade que, tendo em vista a autonomia dos processos de controle incidental ou concreto e de controle abstrato, entre nós, mostra-se possível um distanciamento temporal entre as decisões proferidas nos dois sistemas (decisões anteriores, no sistema incidental, com eficácia ex tunc e decisão posterior, no abstrato, com eficácia ex nunc). Esse fato poderá ensejar uma grande insegurança jurídica. Daí parecer razoável que

${ }^{17}$ STF, MS 26604/DF, Min. Cármen Lúcia, Tribunal Pleno, DJ: 04/10/2007; STF, MS 26603/DF, Min. Celso de Mello, Tribunal Pleno, DJ: 04/10/2007

${ }^{18}$ STF, RE 442683-8/RS, Min. Carlos Velloso, Segunda Turma, DJ: 13/12/2005 
o próprio STF declare, nesses casos, a inconstitucionalidade com eficácia ex nunc na ação direta, ressalvando, porém, os casos concretos já julgados ou, em determinadas situações, até mesmo os casos sub judice, até a data de ajuizamento da ação direta de inconstitucionalidade. Essa ressalva assenta-se em razões de índole constitucional, especialmente no princípio da segurança jurídica. Ressalte-se aqui que, além, da ponderação central entre o princípio da nulidade e outro princípio constitucional, com a finalidade de definir a dimensão básica da limitação, deverá a Corte fazer outras ponderações, tendo em vista a repercussão da decisão tomada no processo de controle in abstracto nos diversos processos de controle concreto. [...] Assim, configurado eventual conflito entre o princípio da nulidade e o princípio da segurança jurídica, que, entre nós, tem status constitucional, a solução da questão há de ser, igualmente, levada a efeito em um processo de complexa ponderação. [...] Desse modo, em muitos casos, há de se preferir a declaração de inconstitucionalidade com efeitos restritos à insegurança jurídica de uma declaração de nulidade, como demonstram os múltiplos exemplos do direito comparado e do nosso direito ${ }^{19}$.

No âmbito do Direito Administrativo, a segurança jurídica, em seus vários aspectos, aplica-se na manutenção de atos inválidos, na fixação de prazo para anulação de atos viciados, e ainda possibilita a regulação dos efeitos já produzidos pelo ato ilegal $^{20}$.

Tanto a doutrina como a jurisprudência brasileiras só recentemente passaram a invocar o princípio da segurança jurídica como fundamento para a manutenção de atos administrativos inválidos.

A subsistência do ato administrativo inválido era justificado pelo poder discricionário da Administração em decidir entre invalidar ou manter um ato

${ }^{19}$ STF, RE 197917, Tribunal Pleno, Min. Mauricio Correa, DJ: 06/06/2002

${ }^{20}$ DI PIETRO, Maria Sylvia Zanella. "O princípio da proteção à confiança, da segurança jurídica e da boa-fé na anulação do ato administrativo". Fórum Administrativo-Direito Público - FA, Belo Horizonte, ano 9, n. 100. P. $155-166$, jun. 2009 , p. $159-163$ 
administrativo viciado, conforme o interesse público, devidamente sopesado, apontasse num ou noutro sentido, mas não se aludia ao princípio da segurança jurídica ${ }^{21}$.

Segundo noticia Almiro Couto e Silva ${ }^{22}$, as primeiras decisões que reconheceram a segurança jurídica como princípio constitucional na posição de subprincípio do Estado de Direito foram as proferidas nos acórdãos MC 2.900-RS (08.03.2003), MS 24268/MG (15.03.2004), MS 22357/DF( 24.05.2004), todos de relatoria do Ministro Gilmar Mendes.

O primeiro deles (MC 2900) versava sobre situação consolidada em razão de provimento jurisdicional provisório, posteriormente reformado, após decorrido longo período de tempo de tramitação do processo. Tratava-se de ação cautelar objetivando atribuir efeito suspensivo a Recurso Extraordinário interposto contra acórdão proferido pelo Tribunal Regional Federal da $4^{\mathrm{a}}$. Região que reformou a sentença proferida em mandado de segurança, a qual reconheceu o direito da impetrante a ser transferida da Universidade Federal de Pelotas para Universidade Federal do Rio Grande do Sul, em Porto Alegre, uma vez que a mesma, por ter sido aprovada em concurso público, teve que mudar seu domicílio para aquele Município, onde iniciaria sua atividade. Ao conceder liminarmente o efeito suspensivo, o Ministro Gilmar Mendes asseverou que "no âmbito da cautelar, a matéria evoca, inevitavelmente, o princípio da segurança jurídica"23.

O segundo, mandado de segurança impetrado por pensionista, na qualidade de beneficiária adotada, contra ato do Tribunal de Contas que cancelou o pagamento de sua pensão, concedida há dezoito anos, sob o argumento de que a adoção não fora comprovada por instrumento jurídico adequado. A impetrante fundamentou-se na alegação de que o cancelamento se deu de forma unilateral e arbitrária, sem que lhe fosse assegurado contraditório e ampla defesa. O Ministro Gilmar Mendes, em seu voto, apesar de ter concedido a ordem sob o fundamento alegado pela impetrante - ausência de contraditório e ampla defesa -, uma vez que havia sido esta a causa de pedir, ressaltou haver um "quid relacionado com a segurança jurídica a recomendar, no mínimo, maior cautela em caso como o dos autos", e após mencionar pronunciamentos doutrinários sobre

\footnotetext{
${ }^{21}$ SILVA, Almiro do Couto e. "O princípio da segurança jurídica(proteção à confiança) no direito público brasileiro e o direito da Administração Pública de anular seus próprios atos administrativos: o prazo decadencial do art. 54 da Lei do Processo Administrativo da União (Lei 9.784/99)". Revista Eletrônica de Direito do Estado, Salvador, Instituto de Direito Público da Bahia, n. 2, abril/maio/junho, 2005. Disponível na Internet: [http://www.direitodoestado.com.br]. Acesso em 12 de março de 2013.

${ }^{22}$ Idem, ibidem

${ }^{23}$ Idem, ibidem
} 
segurança jurídica concluiu: "É possível que, no caso em apreço, fosse até de se cogitar da aplicação do principio da segurança jurídica, de forma integral, de modo a impedir o desfazimento do ato" 24 .

No terceiro acórdão, proferido no MS 22357/DF, o Ministro fez referencia expressa ao aspecto subjetivo da segurança jurídica, ou seja, à boa-fé dos impetrantes para justificar a concessão da segurança. O caso versou sobre contratações efetuadas pela empresa estatal INFRAERO, sem concurso público.

$\mathrm{O}$ art. 173, $\S 2^{\circ}$, da Constituição Federal, na sua redação originária determinava que "A empresa pública, a sociedade de economia mista e outras entidades que explorem atividade econômica sujeitam-se ao regime jurídico das empresas privadas, inclusive quanto às obrigações trabalhistas e tributárias”. Tendo em vista a controvérsia existente à época quanto a necessidade de realização de concurso público para contratação pelas empresas públicas face ao disposto no citado art.173, o Tribunal de Contas da União, em decisão proferida em 06.06.1990, firmou entendimento acerca da necessidade de concurso público, e que só deveriam ser anulados os atos de admissão a partir daquela data e não os realizados anteriormente. Mas, ao julgar as contas da INFRAERO, referente ao exercício de 1991, alterou sua posição, assentando que a empresa deveria regularizar as 366 admissões, sob pena de nulidade ${ }^{25}$.

O Ministro Gilmar Mendes assim se pronunciou sobre o caso:

Vale lembrar que o próprio Tribunal de Contas da União aceitou a situação de fato existente à época, convalidando as contratações e recomendando a realização de concurso público para admissões futuras. Observa-se que mais de 10 anos já se passaram em relação às contratações ocorridas entre janeiro de 1991 e novembro de 1992, restando constituídas situações merecedoras de amparo. [...] Dessa forma, meu voto é no sentido do deferimento da ordem, tendo em vista as específicas e excepcionais circunstancias do caso em exame. E aqui considero sobretudo: a boa fé dos impetrantes, a existência de processo seletivo rigoroso e a contratação conforme o regulamento da

\footnotetext{
${ }^{24}$ Idem, ibidem

${ }^{25}$ SILVA, Almiro do Couto e. "O princípio da segurança jurídica(proteção à confiança) no direito público brasileiro e o direito da Administração Pública de anular seus próprios atos administrativos: o prazo decadencial do art. 54 da Lei do Processo Administrativo da União (Lei 9.784/99)". cit..
} 
INFRAERO; a existência de controvérsia à época da contratação, quanto à exigência de concurso público, nos moldes do art. 37, II, da Constituição, no âmbito das empresas públicas e sociedades de economia mista; o fato de que houve dúvida quanto à correta interpretação do art. 37 , II, em face do art. $173, \S 1^{\circ}$, no âmbito do próprio TCU; o longo período de tempo transcorrido das contratações e a necessidade de garantir segurança jurídica a pessoas que agiram de boa $\mathrm{fe}^{26}$.

Como se vê, o principio da segurança jurídica, seja sob o aspecto objetivo ou sob o aspecto subjetivo (proteção à confiança) encontra-se atualmente reconhecido tanto pela legislação como pela jurisprudência do Supremo Tribunal Federal, tendo aplicação em todas as esferas de Governo - União, Estados-membros, Distrito Federal e Municípios - e em todas as funções do Estado - Legislativo, Judiciário e Executivo.

No tocante à sua incidência no Poder Executivo, o principio da segurança jurídica impõe limites à invalidação do ato administrativo eivado de vício de ilegalidade ou inconstitucionalidade. Assim, por estar intimamente relacionado ao Estado de Direito, deve ser considerado em toda a atuação administrativa, mas em especial quando o agente público estiver diante de ato eivado de ilegalidade ou inconstitucionalidade e tiver de decidir entre sua invalidação ou convalidação.

${ }^{26}$ Idem, ibidem 


\section{RESTAURAÇÃO DA LEGALIDADE}

Ao inaugurar o capítulo VII, do Título III, da Constituição Federal, assim estabeleceu o legislador constituinte no art. : “A administração pública direta e indireta de qualquer dos Poderes da União, dos Estados, do Distrito Federal e dos Municípios obedecerá aos princípios da legalidade, impessoalidade, moralidade, publicidade e eficiência..."

O norte primordial da Administração Pública, portanto, há de ser o princípio da legalidade, que segundo Gilmar Ferreira Mendes, Inocêncio Martires Coelho e Paulo Gustavo Gonet Branco ${ }^{1}$,

significa, nos termos do art. $5^{\circ}$, inciso II, da nossa constituição, que ninguém será obrigado a fazer ou deixar de fazer alguma coisa senão em virtude de lei, um preceito multifuncional cujo núcleo essencial se espraia e se especifica no âmbito do ordenamento jurídico, dando origem a múltiplas expressões - processo legislativo, devido processo legal, supremacia da lei, perante a lei, reserva de lei, anterioridade da lei, vigência da lei, incidência da lei, retroatividade e ultra-atividade da lei, repristinação da lei, lacunas da lei, legalidade administrativo, legalidade penal e legalidade tributária, entre outras - as quais, embora distintas em sua configuração formal, substancialmente traduzem uma só e mesma ideia, a de que a lei é o instrumento por excelência de conformação jurídica das relações sociais. (grifo nosso)

Assim, deve a Administração submeter-se ao princípio da legalidade, que em sua acepção ampla significa predomínio da lei, submissão ao império da lei. Por isso, é ela a principal interessada em fazer uso de meios que garantam essa sua atuação de acordo com a lei.

Por outro lado, não se pode desconsiderar que a finalidade precípua da atividade administrativa do Estado é atender ao interesse público.

\footnotetext{
${ }^{1}$ MENDES, Gilmar Ferreira, COELHO, Inocêncio Martires, BRANCO, Paulo Gustavo Gonet. Curso de Direito Constitucional. 4.ed. São Paulo: Saraiva, 2009, p. 180
} 
A obediência à lei e o atendimento do interesse público são os balizadores que guiam a Administração Pública na concretização de suas atividades.

Portanto, todo ato administrativo que seja editado em desconformidade com a lei - considerada em sentido amplo - presume-se contrário ao interesse público.

Percebe-se também que todo ato administrativo que deixe de atender o interesse público torna-se ilegal, conforme será demonstrado quando tratarmos da revogação. Um ato administrativo pode ser inválido ou porque ao ser editado, o foi com afronta direta à lei, ou ao interesse público, ou tornou-se inválido pela ocorrência de fato superveniente que o tornou inconveniente ao interesse público. E a Administração Pública não pode conviver com situações como estas. Diante de tais hipóteses, fundamentada no princípio da autotutela, deve se utilizar de meios que restabeleçam a legalidade e, consequentemente, sua atuação em conformidade com interesse da coletividade.

Hely Lopes Meirelles ${ }^{2}$ entende que a única opção da Administração Pública diante de um ato inválido é a sua retirada, por meio de invalidação, afirmando que

se por erro, culpa, dolo ou interesses escusos de seus agentes, a atividade do Poder Público desgarra-se da lei, divorcia-se da moral ou desvia-se do bem comum, é dever da Administração invalidar, espontaneamente ou mediante provocação, o próprio ato, contrário a sua finalidade, por inoportuno, inconveniente, imoral ou ilegal.

No entanto, grande parte da doutrina e jurisprudência entendem possíveis outras formas de restauração da legalidade. Adotamos, neste ponto, a orientação de Edmir Netto de Araújo $^{3}$ para quem a obrigatoriedade da Administração Pública, em face de situação de ilegalidade, é restaurar a legalidade, o que pode ser conseguido tanto pela invalidação como pela convalidação.

A legalidade pode ser restabelecida tanto pela retirada do ato administrativo inválido, através da anulação ou revogação, como pela manutenção do ato, quando possível “consertá-lo”, por meio da convalidação, conversão ou ratificação.

\footnotetext{
${ }^{2}$ MEIRELLES, Hely Lopes. Direito Administrativo Brasileiro. 27. ed. São Paulo: Malheiros, 2002.

${ }^{3}$ ARAÚJO. Edmir Netto de. Convalidação do Ato Administrativo. São Paulo: LTr, 1999, p. 119.
} 
Embora tecnicamente não se trate de restauração da legalidade, outra possibilidade é a manutenção do ato ilegal sem alterá-lo, quando não possível a convalidação e, sua invalidação acarretar um maior prejuízo ao interesse público, porque as relações dele decorrentes se estabilizaram pelo transcurso do tempo.

Trataremos a seguir detalhadamente de cada uma destas possibilidades de restabelecimento da legalidade ferida deixando para o capitulo da prescrição e decadência o tema relativo a manutenção do ato sem alterá-lo. 


\section{RETIRADA DO ATO ADMINISTRATIVO INVÁLIDO: REVOGAÇÃO, ANULAÇÃO OU INVALIDAÇÃO}

Como proceder para retirar do mundo jurídico um ato administrativo contrário ao interesse público, seja porque afrontou diretamente a lei, seja porque se tornou inconveniente ou inoportuno pela ocorrência de fato posterior?

Uma das formas de restauração da legalidade pela Administração é produzir outro ato administrativo retirando aquele do mundo jurídico.

Na lição de Hely Lopes Meirelles ${ }^{1}$, invalidação é o gênero, do qual a revogação e a anulação são espécies. A diferença entre as espécies é o seu motivo. $\mathrm{Na}$ revogação temos a supressão de um ato administrativo que se tornou inconveniente ou inoportuno ao interesse público. Já na anulação o desfazimento do ato administrativo se faz em razão de sua ilegalidade na origem.

Outros autores, no entanto, consideram invalidação e revogação espécies distintas de desfazimento do ato administrativo. Empregam o vocábulo invalidação ou anulação para designar somente as hipóteses de retirada do ato administrativo por motivo de ilegalidade. Esta será a corrente adotada neste trabalho.

\subsection{Revogação}

\subsubsection{Conceito de revogação}

Revogação é a extinção de um ato administrativo e ou de seus efeitos por outro ato administrativo por motivo de conveniência e oportunidade, respeitando-se os efeitos já produzidos. Pela revogação, elimina-se ou substitui-se ato anterior que se tornou contrário ao interesse público.

\subsubsection{Espécies de revogação}

A revogação pode ser expressa ou tácita. Quando a autoridade administrativa edita ato administrativo que declara expressamente a revogação de outro ato

\footnotetext{
${ }^{1}$ MEIRELLES, Hely Lopes. Direito Administrativo Brasileiro. 25. ed. São Paulo: Malheiros, 2000, p.189-191
} 
administrativo, estamos diante de uma revogação expressa. Há também, a possibilidade de o ato revogador, apenas dispor de forma diversa e incompatível com a situação existente. Esta hipótese trata-se de revogação tácita. É possível também que o ato revogador, além de dispor sobre a matéria tratada no ato revogado, determine expressamente a revogação do ato anterior.

Há, ainda, a revogação parcial e total, conforme a amplitude com que afeta o ato anterior. Diógenes Gasparini ${ }^{2}$ ilustra estas espécies de revogação por meio de dois exemplos: a Administração Pública retira (revoga) um ato administrativo que declarou um bem de utilidade pública para fins expropriatórios para a construção de um pronto-socorro, porque nas proximidades o Estado iniciou uma edificação com a mesma finalidade; a Administração Pública extingue somente a permissão de uso de um bem móvel, outorgada juntamente com a permissão de uso de um bem imóvel. O primeiro exemplo trata-se de revogação total, uma vez que elimina-se todo o ato administrativo e o segundo exemplo refere-se a revogação parcial, pois somente é retirado do ordenamento jurídico parte do ato (a permissão de uso de bem móvel).

\subsubsection{Objeto da revogação}

A revogação incide sobre o ato administrativo que, embora legítimo quando de sua edição, tornou-se inconveniente ou inoportuno ao interesse público. Costuma-se dizer que o objeto da revogação é o ato válido, porém, que não mais atende ao interesse público. No entanto, conforme será demonstrado a seguir, não consideramos tecnicamente correto falar em ato válido e em desacordo com o interesse público. $\mathrm{O}$ ato administrativo só será válido enquanto conforme ao interesse público, na medida em que o atendimento ao interesse público é condição de validade do ato administrativo.

\subsubsection{Competência revogatória}

Tem competência para promover a revogação, somente a Administração Pública, uma vez que se trata de questão de aferição de conveniência ou oportunidade em

\footnotetext{
${ }^{2}$ GASPARINI, Diógenes. Direito Administrativo. 14. ed. São Paulo: Saraiva, 2009, p. 106
} 
relação ao atendimento ao interesse público, e só quem tem competência para fazê-lo é a própria autoridade editora do ato, em contato direto com a realidade administrativa ${ }^{3}$.

O Legislativo e Judiciário podem exercer esta competência revogatória em relação aos atos por eles produzidos no exercício da competência administrativa. A um Poder não compete revogar o ato do outro, sob pena de ofensa ao princípio da separação dos poderes insculpidos no art. $2^{\circ}$ da Constituição Federal.

Em relação ao agente, é competente para produzir ato de revogação o mesmo que produziu o ato anterior ou ainda, aquele que na escala hierárquica, seria competente para praticá-lo ou ordená-lo em substituição a autoridade inferior omissa.

\subsubsection{Natureza jurídica e efeitos da revogação}

A revogação tem natureza de ato administrativo desconstitutivo, pois objetiva suprimir total ou parcialmente os efeitos de ato legítimo anterior ${ }^{4}$.

Por se tratar de desfazimento do ato administrativo que, embora legalmente constituído se tornou contrário ao interesse público, a revogação produz efeitos ex nunc, ou seja, para o futuro, preservando-se os efeitos produzidos pelo ato revogado até então. Isso porque o ato revogado foi válido enquanto durou, e consequentemente, válidos também foram os seus efeitos.

\subsubsection{Motivo da revogação}

Tradicionalmente, a revogação é considerada como a retirada do mundo jurídico do ato administrativo legal, porém inconveniente ou inadequado ao interesse público.

Ora, se assim é, a revogação não poderia ser considerada forma de restauração da legalidade, pois não haveria o que restaurar. $\mathrm{O}$ ato seria legítimo, tendo somente se tornado contrário ao interesse público.

No entanto, considerando-se que o fundamento primordial, a própria razão de existir da atividade administrativa, é a realização do interesse público, sempre que se

\footnotetext{
${ }^{3}$ ARAÚJO. Edmir Netto de. Convalidação do Ato Administrativo. São Paulo: LTr, 1999, p. 108

${ }^{4}$ Idem, ibidem, p. 109
} 
verificar um descompasso entre ambos, estaremos diante de uma ilegalidade ou ilegitimidade, ainda que superveniente à prática do ato.

Assim, podemos dizer que o ato será ilegal quando sua finalidade for contrária àquela descrita na lei, ou será ilegítimo quando, embora sua finalidade esteja conforme determinação legal, esta não atende efetivamente aos anseios da coletividade. E a Administração Pública não pode conviver com situações que sejam contrárias ao interesse público.

Fala-se, ainda, que a revogação é a forma de extinção do ato administrativo por vício de mérito.

O mérito do ato administrativo diz respeito ao binômio conveniência/oportunidade e está diretamente relacionado à discricionariedade.

É comum conceituar discricionariedade como liberdade de ação necessária à realização da atividade administrativa. Quando se fala em liberdade de ação, a primeira impressão é que se faculta ao agente público escolher o momento, o motivo e o conteúdo do ato que vai praticar de acordo com critérios pessoais seus.

Porém, não se há de esquecer que embora a lei, por impossibilidade de determinar especificamente, no caso concreto, qual solução mais adequada ao interesse público, confira esse poder ao administrador, também exige dele que se vincule ao atendimento de uma finalidade (de interesse público).

A norma, nestes casos, deixa ao administrador a incumbência de escolher, no caso concreto, qual a solução que seria dada por ela ao se defrontar com aquela específica situação. Mas, o agente não é livre para dispor conforme suas convicções pessoais. Ele deve interpretar a lei, buscando seu significado em outros textos legais, nos princípios constitucionais e nos princípios gerais do Direito. Estabelecida com maior exatidão a finalidade legal, deverá o agente passar à análise do caso concreto, utilizando-se de sua inteligência para dar uma solução racional, levando em conta as peculiaridades da situação ${ }^{5}$.

Assim, na maioria das vezes, utilizando o agente público de sua razão e procedendo da forma acima descrita, chegará a uma única solução, exatamente aquela que melhor atende ao interesse público. Nestes casos, o fato de a lei deixar ao agente público o

\footnotetext{
${ }^{5}$ SUNDFELD, Carlos Ari. Ato administrativo inválido. São Paulo: Revista dos Tribunais, 1990, p. 35
} 
poder/dever de determinar o momento, o motivo e o conteúdo do ato a ser praticado, não significa que the tenha conferido uma liberdade absoluta, mas sim que se socorre de sua inteligência como ser racional para chegar à única solução possível ao caso concreto.

Somente haverá verdadeiramente discricionariedade quando o administrador ultrapassar o limite além do qual não há consenso sobre qual decisão seria a correta, ou seja, quando não for possível imputar-lhe erro, mesmo que intimamente seja preferível outra solução ${ }^{6}$.

Discricionariedade, de acordo com Carlos Ari Sundfeld é

o dever-poder de o administrador, após um trabalho de interpretação e de racional confronto da norma com os fatos - apreciação objetiva, sempre controlável - e sendo ainda impossível, com base nele, descobrir qual a melhor decisão para o caso concreto, fazer uma apreciação volitiva para determina-la ${ }^{7}$.

Baseado nesta noção de discricionariedade é possível afirmar que todo vício de mérito é vício de legalidade ${ }^{8}$. Isto porque, se na aplicação da lei ao caso concreto, só existe uma solução que atenda sua finalidade, ou o ato esta de acordo com esta finalidade e, neste caso é legal, ou o agente adotou outra solução que não atende adequadamente ao interesse público, e o ato é ilegal.

Pode-se dizer então que o que distingue revogação e anulação não é o motivo pois, como demonstrado, em ambos será ilegalidade. A diferença reside no momento em que a ilegalidade ocorre. Se é originária, ou seja, concomitante com a edição do ato administrativo, ela ensejará a anulação e, portanto, extinguem-se todos os efeitos produzidos, porque desde a origem já era ilegal. Se é superveniente, pela ocorrência de fatos posteriores à sua edição que tornem o ato inconveniente ao interesse público, a medida correta será a revogação, uma vez que através desta medida respeitam-se os efeitos já produzidos pelo ato, porque até então decorriam de um ato legal.

Desta forma, é fácil notar que a revogação também é uma forma de restaurar a legalidade (em sentido amplo), uma vez que a atuação de acordo com o

\footnotetext{
${ }^{6}$ Idem, ibidem, p. 34

${ }^{7}$ Idem, ibidem, p. 34

${ }^{8}$ Idem, ibidem, p. 34
} 
interesse público encontra-se inserida no sentido da legalidade administrativa, conforme explanado em capítulo antecedente.

\subsubsection{Limites ao poder de revogação dos atos administrativos}

Quando falamos em limite ao poder de revogar é importante a distinção entre os atos gerais abstratos e os atos concretos.

Os atos abstratos, semelhantes à lei, não dispõe sobre situações pessoais, individualizadas, pelo que sua manutenção não se caracteriza como direito subjetivo individual. Podem ser revogados a qualquer tempo e em quaisquer circunstâncias.

Diversamente, no caso dos atos concretos, a revogação extingue uma relação jurídica existente, para dispor de outro modo. Embora respeite os efeitos passados, alcança uma situação atual, suprimindo seus efeitos. Por isso, pode gerar situações irrevogáveis ${ }^{9}$.

Assim, são irrevogáveis:

a) atos que a lei assim os declare;

b) os atos vinculados, porque ao praticá-los, a Administração Pública esgotou sua competência, adotando a única solução possível prevista na lei;

c) os atos que exauriram seus efeitos, pois a revogação impede que o ato continue produzindo efeitos e se estes já se esgotaram, não há o que ser atingido pela revogação;

d) os meros atos administrativos, como as certidões, atestados, porque os efeitos deles decorrentes são estabelecidos pela lei;

e) os atos que integram um procedimento, pois a cada ato sucessivo, operase a preclusão do anterior;

f) os atos que geram direitos adquiridos, uma vez que a Constituição os declara intangíveis;

g) os atos de controle, pois a competência extingue-se a cada situação examinada assim que expedido o ato;

\footnotetext{
${ }^{9}$ MELLO, Celso Antonio Bandeira. Curso de Direito Administrativo. 17. ed. São Paulo: Malheiros, 2004, p. 418.
} 
h) os atos complexos, pois são fruto da manifestação de vontade de mais de um órgão, não podendo ser modificados pela decisão de um só.

Segundo alguns autores alemães, por estenderem ao ato administrativo a força jurídica da coisa julgada, só seriam revogáveis os atos, aos quais a lei conferisse esta faculdade à Administração Pública. Portanto, para esta corrente, que encontra em Merkel seu principal adepto, a regra geral seria de irrevogabilidade dos atos administrativos. No entanto, esta orientação não prevalece, contrapondo-se a ela Otto Mayer, Fritz Fleiner e Forsthoff que mesmo admitindo a irrevogabilidade de certos atos, entendem que caso a mesma seja imperativa para atendimento de interesse público, os direitos adquiridos devem ser indenizados ${ }^{10}$.

\subsubsection{Irrevogabilidade e indenização}

Em regra, a revogação, quando cabível, não gera à Administração Pública o dever de indenizar, uma vez que normalmente não lesa direito algum de terceiro.

Entretanto, há situações que embora se tratando de atos irrevogáveis, razões de interesse público determinam a necessidade de revogá-los. Nesse caso, o Estado deverá promover a indenização, recompondo os prejuízos causados ao particular com fundamento na responsabilidade do Estado por ato lícito.

Disso é exemplo, a revogação de licença para construir - ato vinculado e, portanto, irrevogável - em decorrência da alteração da legislação concernente ao zoneamento municipal, incompatível com aquele tipo de construção licenciada anteriormente.

Nesse sentido, as lições de Oswaldo Aranha Bandeira de Mello ${ }^{11}$ :

\footnotetext{
${ }^{10}$ MERKEL, Adolfo. Teoría General del Derecho administrativo, Trad. da ed. alemão de 1927. Madrid. Editorial Revista de Derecho Privado, 1935, p.253-258; MAYER, Le Droit Administratif Allemand. vol I, ed. Francesa. Paris, M. Giard et E. Brière, Libraires-Éditeurs, 1903, pp 253-272; FLEINER, Fritz. Les Principes Généraux du Droit Administratif Allemand. Trad. da $8^{\circ}$ ed. alemã de 1928. Paris, Librairie Delagrave, 1933, pp.124-126; FORSTHOFF, Ernest. Tratado de Derecho Administrativo. Trad. da $5^{\text {a }}$ ed. alemã. Madrid, Instituto de Estudios Políticos, 1958 (em Frances: Traité de Droit Administratif Allemand, 1969, pp. 346-356 apud MELlO, Oswaldo Aranha Bandeira de. Princípios Gerais de Direito Administrativo. São Paulo: Malheiros, $3^{\circ}$ ed. , 2007, pp. 648-649

${ }^{11}$ MELLO, Oswaldo Aranha Bandeira de. Princípios Gerais de Direito Administrativo. São Paulo: Malheiros, $3^{\circ}$ ed. , 2007, p. 642
} 


\begin{abstract}
Mudando a situação de fato que originou o direto adquirido ou o regime jurídico que o rege, em virtude de lei ou mesmo de ato administrativo, sob pena de desmentir a função administrativa os seus objetivos de criar e melhorar a utilidade pública, torna-se imprescindível a revogação ou reforma, por vezes, de atos administrativos anteriores, que geraram direitos adquiridos a favor de terceiros, nos seus efeitos futuros. Como esse direito, entretanto, é suscetível de conversão em expressão monetária, não deixará de ficar resguardado às completas, mesmo sendo revogado $o$ ato administrativo que originou essa relação jurídica, indenizado, de modo pleno, seu titular.
\end{abstract}

Celso Antônio Bandeira de Mello ${ }^{12}$ entende que em casos como este, onde há a necessidade de revogação de um ato administrativo irrevogável - e, portanto, lesivo ao interesse de terceiros - a solução é promover a desapropriação do direito, com a consequente indenização prévia, justa e em dinheiro. Afirma o autor que "a lei prevê o instituto da expropriação quando é irredutível o choque entre um interesse público e um direito do administrado".

Diógenes Gasparini ${ }^{13}$ discorda afirmando que tal solução não é aceitável em nosso ordenamento jurídico, por não existir previsão legal deste fundamento para desapropriação (mudança do ordenamento), cujas hipótese são taxativas.

O importante é que de uma forma ou de outra o resultado é o mesmo: a indenização do particular em razão de ter tido direito legítimo seu lesado por um ato da Administração Pública.

Assim, preferimos adotar a posição de que a revogação de atos administrativos irrevogáveis, certamente causa lesão a direitos individuais e, portanto, pressupõe uma indenização, não como consequência do procedimento expropriatório que, muitas vezes é longo e dispendioso, mas tendo como fundamento a responsabilidade civil do Estado.

\footnotetext{
${ }^{12}$ MELLO, Celso Antonio Bandeira. Curso de Direito Administrativo. cit., p. 420

${ }^{13}$ GASPARINI, Diógenes. Direito Administrativo. cit., p.109
} 


\subsection{Anulação ou invalidação}

\subsubsection{Questões terminológicas}

Há divergência quanto à utilização dos termos invalidação e anulação. Alguns consideram expressões sinônimas, utilizando-as indistintamente. Outros, distinguem invalidação de anulação, utilizando como critério diferenciador o sujeito que desfaz o ato administrativo ilegal. Quando a extinção é feita pela própria Administração é designada por invalidação. Quando a supressão do ato provier do Poder Judiciário, utilizase o termo anulação.

Sundfeld ${ }^{14}$, embora reconheça serem expressões sinônimas, prefere utilizar invalidação, sob o fundamento de que a anulação está diretamente relacionada as categorias de nulidade e anulabilidade tratadas pela teoria das nulidades do Direito Civil, podendo dar impressão da adoção desta teoria no Direito Administrativo.

Por questão metodológica, ao tratarmos da retirada do ato administrativo eivado de vício desde sua origem utilizaremos a expressão anulação, até mesmo por força do disposto na Sumula 473, do STF: "a Administração pode anular seus próprios atos, quando eivados de vícios que os tornem ilegais, porque deles não se originam direitos, ou revoga-los, por motivo de conveniência ou oportunidade, respeitados os direitos adquiridos e ressalvada, em todos os casos, a apreciação judicial".

\subsubsection{Conceito de anulação}

Anulação é a retirada de um ato administrativo ou da relação jurídica dele nascida em razão de sua desconformidade com o ordenamento jurídico. Diferentemente da revogação que pode ser tácita, a anulação é sempre expressa.

\subsubsection{Competência para anulação}

Podem proceder a anulação tanto a Administração Pública como o Poder Judiciário. A Administração pode anular seus próprios atos, seja mediante provocação do interessado, seja por denuncia de terceiros, ou ainda, espontaneamente, quando tiver conhecimento de alguma ilegalidade. O Poder Judiciário somente pode anular ato administrativo quando provocado, no curso de uma ação.

${ }^{14}$ SUNDFELD, Carlos Ari. Ato administrativo inválido. cit., p. 28 
No âmbito da Administração Pública, a competência para anular é do agente que praticou o ato ou de outro agente superior dentro da hierarquia administrativa, ou ainda, aquele que a lei indicar como competente de rever o ato.

Já em relação ao Judiciário, por se tratar de atividade jurisdicional, por óbvio, somente o juiz tem referida competência.

\subsubsection{Objeto da anulação}

Pode ser objeto da anulação tanto o ato administrativo ilegal como a relação jurídica dele originada.

Em se tratando de atos ineficazes, sejam eles abstratos ou concretos, o que se anula é o próprio ato, uma vez que ainda não produziu qualquer efeito, ou seja, não constituiu qualquer relação jurídica.

Caso o ato administrativo já esteja apto a produzir efeitos ou já os tenha produzido (atos eficazes) é necessário diferenciar os atos abstratos dos atos concretos.

Os atos abstratos são uma fonte contínua de efeitos, ou seja, permanentemente estão criando relações jurídicas. Neste caso, a anulação incidirá sobre o próprio ato e sobre as relações jurídicas já constituídas.

Os atos concretos, ao contrário dos abstratos, só se aplicam a uma única situação, ou seja, criam uma única relação jurídica e, por isso, extinguem-se em seguida. $O$ que perdura não é o ato e sim os efeitos por ele produzidos. Nesta hipótese, a anulação incidirá somente sobre a relação jurídica produzida, porque o ato em si já se exauriu com a eclosão de seus efeitos.

\subsubsection{Natureza jurídica e efeitos da anulação}

A anulação é ato declaratório, uma vez que apenas declara uma situação preexistente: a invalidade de outro ato ou da relação jurídica dele originada. Conforme afirma Edmir Netto de Araújo ${ }^{15}$ a anulação é ato "declaratório do estado patológico ou mesmo de inexistência do ato anteriormente editado".

${ }^{15}$ ARAÚJO. Edmir Netto de. Convalidação do Ato Administrativo. cit., p. 109 
Diferentemente do que ocorre na revogação, em que a ilegalidade (vício de mérito) é superveniente a edição do ato administrativo, na anulação a ilegalidade é originária, ou seja, ocorre na produção do ato. Por isso, regra geral, produz efeitos ex tunc, ou seja, volta para o passado, desconstituindo todos os efeitos que o ato viciado já produziu.

Porém, há situações em que, o ato ilegal amplia a esfera de direitos de seus destinatários de boa-fé e por razões de segurança jurídica e proteção à confiança admite-se a intangibilidade de alguns ou de todos os efeitos pretéritos do ato.

\subsubsection{Anulação e indenização}

Uma das características do ato administrativo é a sua presunção de legitimidade. Desta forma, se a Administração atuou de forma contrária a ordem jurídica, envolvendo terceiros que, de boa-fé, sem conhecimento da ilegalidade, desenvolveram atividade dispendiosa, nada mais justo que ao proceder a anulação do ato ilegal, deva indenizar os prejuízos que causou a aqueles que acreditaram na lisura do provimento administrativo.

Este dever de indenizar encontra fundamento no art. $37, \S 6^{\circ}$, da Constituição Federal que estabelece a responsabilidade do Estado por atos ilícitos ou lícitos (como seria a correta anulação do ato inválido).

\subsubsection{Direito de resistência contra atos inválidos}

Deve-se diferenciar a resistência consistente no simples descumprimento de uma determinação administrativa, da resistência manu militari na qual o administrado utiliza-se de força física para opor-se a execução material de um provimento administrativo.

De acordo com Celso Antônio Bandeira de Mello ${ }^{16}$, o direito de resistência manu militari só é admitida em relação a atos inexistentes, ou seja, "aqueles que prescrevem a prática de crimes e expõem o administrado a sofrê-los". Em relação aos demais atos inválidos, o direito de resistência manu militari configuraria uma perturbação à ordem e paz social e por isso não é admitido.

${ }^{16}$ MELLO, Celso Antonio Bandeira. Curso de Direito Administrativo. cit, p. 442 
A resistência passiva pode ocorrer, porém, por conta e risco do administrado. Deixando de cumprir um ato que considera ilegal, o administrado estará fazendo um juízo antecipado de sua legalidade. Isso poderá ser confirmado ou não pela Administração Pública ou Poder Judiciário. Caso o ato seja declarado ilegal pelas instancias competentes, sua resistência será tida como legítima. Ao contrário, se não declarada a ilegalidade do ato, sua resistência será havida como ilegítima e certamente o administrado sofrerá as consequências do descumprimento do ato.

\subsubsection{Limites à anulação}

Embora grande parte da doutrina considere a anulação do ato administrativo ilegal pela Administração pública uma obrigatoriedade, conforme explanamos em capítulo antecedente, compartilhamos as lições de Edmir Netto de Araújo ${ }^{17}$, no sentido que não há um dever legal de anulação ou convalidação e sim de restauração da legalidade.

Desta forma, cumpre analisar quais parâmetros devem ser observados pelo administrador para encontrar a melhor forma de restaurar a legalidade. Dentre tais parâmetros encontram-se as hipóteses em que a anulação não poderá ser realizada.

Em se tratando de atos inválidos ampliativos de direito, a anulação encontra limites nos princípios da segurança jurídica, proteção à confiança e interesse público. Como se vê, é o próprio ordenamento jurídico que impõe limitações, uma vez que tais princípios encontram-se igualmente contemplados.

A limitação imposta pelos princípio da segurança jurídica e proteção à confiança é vista sob vários aspectos: constitui embasamento para imposição de limites temporais à anulação (prescrição e decadência); determina a obrigatoriedade de instauração de processo administrativo, por meio do qual seja assegurado contraditório e ampla defesa sempre que o ato a ser anulado tenha produzido efeitos em relação a terceiros.

O interesse público, norteador de toda atividade administrativa, pode também impedir que se proceda a anulação, em algumas situações excepcionais, em que o prejuízo resultante da anulação possa ser maior que a manutenção do ato inválido. Nesta hipótese, a invalidação assume contornos de atividade discricionária tendo em vista a

${ }^{17}$ ARAÚJO. Edmir Netto de. Convalidação do Ato Administrativo. cit., p. 119. 
indeterminação do conceito legal de interesse público. Será diante do caso concreto que a autoridade terá que sopesar as possibilidades e decidir pela solução que melhor atenda o interesse público. É imperioso, neste caso, que a autoridade administrativa proceda a motivação descrevendo de forma específica e objetiva as razões pelas quais decidiu manter o ato administrativo inválido.

Em relação aos atos restritivos de direito, concordamos com o afirmado por Weida Zancaner ${ }^{18}$, no sentido de inexistir barreira ao dever de invalidá-los.

${ }^{18}$ ZANCANER, Weida. Da convalidação e da invalidação dos atos administrativos. $3^{\mathrm{a}}$ ed. São Paulo: Malheiros, 2008, p.73 


\section{MANUTENÇÃO DOS EFEITOS DO ATO ADMINISTRATIVO INVÁLIDO: A CONVALIDAÇÃO}

\subsection{A terminologia adequada}

O primeiro passo, no estudo de qualquer instituto jurídico, é a análise de sua denominação.

Assim, para falarmos sobre o instituto da manutenção dos efeitos do ato administrativo inválido, temos, primeiramente, que fazer referência à divergência terminológica que lavra sobre o tema.

Edmir Netto de Araújo ${ }^{1}$, depois de advertir que essa terminologia não tem sido nem uniforme, nem precisa, tanto na doutrina nacional como na estrangeira, manifesta sua preferência pela expressão "conservação dos atos administrativos", como gênero, não só por ser mais ampla, como também por designar a atividade que, objetivamente, a Administração desempenha ao utilizar tais instrumentos, e também por se relacionar com o próprio fundamento desta atividade, que é o princípio da conservação dos valores jurídicos.

No entanto, reconhece ele ser a "convalidação" a designação mais utilizada pela doutrina brasileira para designar o gênero das medidas sanatórias, das quais ratificação, conversão, reforma e confirmação são espécies.

José Cretella Junior ${ }^{2}$ e Pietro Virga ${ }^{3}$ utilizam a expressão “convalescimento" como gênero, vendo a convalidação como espécie, para designar os mecanismos de recuperação do ato administrativo inválido de forma que o mesmo possa continuar no mundo jurídico com possibilidade de eficiente atuação.

Adotaremos, por questão metodológica, a expressão "convalidação", como gênero, levando em conta que é a mais utilizada pela doutrina brasileira.

\footnotetext{
${ }^{1}$ ARAÚJO. Edmir Netto de. Convalidação do ato administrativo. São Paulo: LTr, 1999, p. 121-123

${ }^{2}$ CRETELLA JUNIOR, José. Controle jurisdicional do ato administrativo. Rio de Janeiro: Forense, 2001, p. 299

${ }^{3}$ VIRGA, Pietro. Il proccedimento administrativo. Milano: Giuffrè Editore, 1972, p. 497
} 


\subsection{Natureza jurídica da convalidação}

Convalidação, conforme Waldir Vitral ${ }^{4}$, é o "ato por via do qual se corrige um ato jurídico viciado, tornando-o válido".

Legitimar, legalizar, pois, um ato inválido.

Assim, convalidar seria forma de tornar válido o que era originariamente inválido. É o que sustenta Cintra do $\mathrm{Amaral}^{5}$ ao afirmar que "mediante convalidação, torna-se válido o ato administrativo inválido".

Porém, como se pode tecnicamente alterar hoje uma situação que já ocorreu no passado?

Não há como.

Não se pode assim, de forma simplista, definir a convalidação como legitimação, validação, de um ato inválido em sua origem.

Em realidade, a convalidação implica na produção de um novo ato, sem vício, que abarca os efeitos do ato anterior como se seus fossem. Ocorre, portanto, o reconhecimento da invalidade, com a consequente extinção do ato, mas com a preservação de seus efeitos.

A convalidação salva os efeitos produzidos pelo ato inválido, e não o próprio ato.

O ato inválido em si não subsiste. O que permanecem são os seus efeitos, por força, é claro, da convalidação.

Não há validação do ato inválido. Mas apenas de seus efeitos, é bom repetir.

Assim, como afirma Pietro Virga ${ }^{6}$, na convalidação "há a emanação de um provimento novo e autônomo, de caráter constitutivo, o qual se liga ao ato convalidado, com a finalidade de manter firmes seus efeitos a partir do momento em que foi editado".

\footnotetext{
${ }^{4}$ VITRAL, Valder. Vocabulário Jurídico. $4^{\mathrm{a}}$ ed. Rio de Janeiro: Forense, 1986, p. 210

${ }^{5}$ AMARAL, Antonio Carlos Cintra do. Teoria do ato administrativo. Belo Horizonte: Fórum, 2008, p. 101

${ }^{6}$ VIRGA, Pietro. Il provvedimento amministrativo. 4 a . ed. Milano: A. Giuffré Editore, 1972, p. 498

No original: "La convalida quindi comporta l'emanazione di um provvedimento nuovo ed autônomo, di carattere constitutivo, ilqualeperò si ricollegaall'atto convalidadto, al fine dimantenernefemiglieffetti, findal momento in cui esse venne emanto".
} 
A convalidação, portanto, exige, normalmente, a edição de um outro provimento administrativo.

Pode, no entanto, haver convalidação tácita, resultante do silêncio da administração, deixando escoar o prazo para obter sua invalidade?

Sérgio Ferraz ${ }^{7}$ responde positivamente, sustentando possível a convalidação tácita, sem que se toque no ato viciado.

Como na hipótese daqueles atos que, embora possuindo vícios de pequena monta, produzem seus regulares efeitos. E a Administração Pública, deixando escoar o prazo para obter sua anulação, acaba por implicitamente admitir a sua permanência no mundo jurídico. Isso, segundo ele, configuraria uma convalidação tácita ${ }^{8}$.

No entanto, partindo da consideração de que a convalidação pressupõe um novo ato administrativo, resultante da declaração de vontade da Administração, não podemos admitir uma convalidação tácita.

A omissão da Administração, não promovendo a desconstituição do ato inválido, por si só não implica em sua convalidação.

Mais adequada à hipótese, a expressão "sanatória", utilizada por Pietro Virga $^{9}$, para designar essa forma de conservação do ato administrativo inválido.

A sanatória, assim, como forma de conservação dos atos inválidos, caminha paralelamente com a convalidação.

São apontadas duas formas sanatórias ${ }^{10}$ :

a) pela verificação de um pressuposto, que faltava no momento da emanação do ato, como por exemplo, a nomeação de um servidor para ocupar cargo que estava ocupado por outro servidor, ocorrendo a posterior aposentadoria do titular do cargo;

b) pelo cumprimento de um ato preparatório do procedimento que fora omitido. Assim, quando a invalidade resultar da ausência de ato e este realizar-se

\footnotetext{
${ }^{7}$ FERRAZ, Sergio. "Extinção dos atos administrativos". Revista de Direito Administrativo. Rio de Janeiro, vol. 231, jan. mar. 2003, p. 62

${ }^{8}$ Renato Alessi considera convalidação unilateral quando extinto o prazo para particular prejudicado pelo ato inválido de impugná-lo administrativa ou judicialmente. ALESSI, Renato Alessi. Instituiciones de Derecho Administrativo. Trad. Buenaventura Pellisé Prats. Tomo I. Barcelona: Bosh, 1970, p. 340, 341

${ }^{9}$ VIRGA, Pietro. Il Provvedimento amministrativo. cit., p.503

${ }^{10}$ Idem, ibidem, p. 503
} 
posteriormente, ocorrerá a sanatória, ou seja, o ato tornar-se-á válido. Pietro Virga ${ }^{11}$ cita como exemplo de atos sanatórios, a autorização, a aprovação ou perícia técnica.

Diferentemente dos demais atos de conservação, a sanatória não requer a edição de um novo ato. Basta a ocorrência superveniente à edição do ato, de um fato ou do cumprimento de um requisito procedimental exigido para sua validade.

\subsection{Espécies de convalidação}

As várias espécies de convalidação se relacionam com as espécies de vícios do ato administrativo.

\subsubsection{Ratificação}

Quando o vício do ato administrativo é de competência, a sua convalidação se faz com a edição de um novo ato, agora por autoridade competente, do qual deve constar a indicação do vício que o afeta, bem como a expressa manifestação da intenção de removê-lo ${ }^{12}$.

\subsubsection{Conversão}

É a forma de convalidação do ato viciado em seu conteúdo ou objeto. Assim, conversão é "o ato administrativo pelo qual a Administração converte um ato inválido em ato de outra categoria, com efeitos retroativos à data do ato original"13.

O ato inválido é substituído por um ato válido, assegurando-se, embora com outro fundamento, os efeitos visados pelo ato anterior.

Sua utilização ocorre quando o conteúdo ou objeto do ato é ilegal para determinada espécie de ato, porém o ato contém todos os demais elementos e requisitos para validade de outro tipo, produzindo os mesmos efeitos do anterior.

Através da conversão preservam-se somente os efeitos do ato inválido, transformando-o em outro ato. Como exemplo podemos citar a nomeação de alguém para

\footnotetext{
${ }^{11}$ VIRGA, Pietro. Il provvedimento amministrativo. cit., p.503

${ }^{12}$ Idem, ibidem, p.503

${ }^{13}$ DI PIETRO, Maria Sylvia Zanella. Direito Administrativo. 24. ed. São Paulo: Atlas, 2011, p. 251
} 
cargo de provimento efetivo, sem o prévio concurso público, convertida posteriormente em nomeação para cargo de provimento em comissão ${ }^{14}$.

Aproveita-se o mesmo conteúdo - estabelecimento de vínculo entre a pessoa e a Administração Pública -, mas através de outro tipo de ato, com efeitos semelhantes ao anterior.

Cretella Júnior ${ }^{15}$ adverte ser necessário preliminarmente à conversão, apenas declarar a invalidade do ato, sem anulá-lo, pois a eliminação do ato anterior (inválido) impossibilitaria a conversão pela falta do próprio ato a ser convertido.

São pressupostos da conversão: a) invalidade do ato como provimento de um determinado tipo; b) existência neste ato dos elementos e requisitos de um provimento de outro tipo; c) semelhança entre a finalidade de ambos os atos, de forma que permita presumir que a autoridade editora do ato inválido, se soubesse de sua invalidade teria editado o outro ato. ${ }^{16}$

Existem dois tipos de conversão: conversão-provimento e conversãointerpretação.

A conversão-provimento é o aproveitamento dos efeitos do ato inválido com a edição de novo ato de outra categoria ${ }^{17}$. É exemplo uma concessão de uso feita sem licitação, quando esta é exigida. Este ato pode ser convertido em autorização de uso, uma vez que para este tipo de ato não há tal exigência, de forma a conferir validade ao uso do bem público já consentido ${ }^{18}$.

A conversão-interpretação ocorre na aplicação do ato, quando a autoridade administrativa ou judicial reconhecendo a invalidade do ato editado, não o invalida ou anula, por entender estarem presentes os elementos e requisitos de outra categoria de ato, que corresponde à intenção da Administração ao praticá-lo.

As duas espécies de conversão diferem, pois a conversão-provimento pressupõe a prática de novo ato enquanto na conversão-interpretação utiliza-se o mesmo ato, conferindo-lhe os efeitos de outro ato. A conversão-interpretação, nos termos do exposto acima, deverá ser considerada como sanatória, e não como espécie de

${ }^{14}$ CRETELLA JUNIOR, José. Controle jurisdicional do ato administrativo. Rio de Janeiro: Forense, 2001, p. 302

${ }^{15}$ Idem, ibidem, p. 303

${ }^{16}$ VIRGA, Pietro. Il provvedimento amministrativo. cit., p. 512

${ }^{17}$ Idem, ibidem, p. 513

${ }^{18}$ DI PIETRO, Maria Sylvia Zanella. Direito Administrativo. cit., p. 251 
convalidação, uma vez que não há expressa declaração de vontade da Administração Pública por meio da edição de novo ato.

\subsubsection{Confirmação}

Através da confirmação a autoridade administrativa mantém ou reproduz uma anterior determinação, reproduzindo seu conteúdo. Na confirmação não há um reexame do ato com a finalidade de verificar sua legitimidade ou oportunidade, tampouco a intenção de eliminar o vício, não produzindo novo efeito, mas sim expressa a intenção de manter os efeitos do ato originário.

A confirmação se diferencia das demais espécies de convalidação, uma vez que nestas a manifestação de vontade ocorre com a intenção de eliminar o vício originário e naquela a manifestação de vontade objetiva confirmar e manter os efeitos do ato originário sem eliminá-lo ou invalidá-lo. Portanto, a confirmação mantém efetivamente o ato e não somente seus efeitos, conforme ocorre nas demais espécies de convalidação.

Régis Fernandes de Oliveira ${ }^{19}$ muito bem ilustra esta espécie de convalidação com o seguinte exemplo:

autorizou-se um loteamento em terras municipais. O interessado, valendo-se de documentos falsos, logrou obter aprovação do loteamento, seu registro e o competente deferimento perante a própria Prefeitura Municipal a quem pertenciam as terras. $O$ ato que determinou a expedição do alvará autorizando a realização do loteamento é nulo. E a nulidade advém do conteúdo do ato. $\mathrm{O}$ loteamento não poderia ser autorizado, uma vez que situado dentro de imóvel municipal. Inobstante, famílias adquiriram lotes construíram casas, introduziram-se melhoramentos, cobrados foram tributos incidentes sobre eles, bem como tarifas de água, etc. Enfim, onde era terreno municipal erigiu-se verdadeira cidade. Anos após descobre-se que o terreno não pertencia ao loteador e que se trata de área municipal. Imagine-se, mais, que se tratava de verdadeiro paul, que foi sanado pelos adquirentes e, o que era um terreno totalmente inaproveitável, tornou-se valorizado.

${ }^{19}$ OLIVEIRA, Regis Fernandes de. Ato administrativo. 5. ed. São Paulo: Revista dos Tribunais, 2007, p. 153 
Nesta hipótese, fundamentado no princípio do interesse público, a Administração poderá se utilizar da convalidação, ou mais especificamente da confirmação, mantendo-se íntegro tanto o ato como os efeitos por ele produzidos.

\subsubsection{Reforma}

Utiliza-se a reforma para suprimir de certo ato administrativo sua parte inválida, mantendo-se a eficácia da parte não comprometida pela ilegalidade, desde que possível a subsistência do ato sem a parte afetada pelo vício. Cite-se como exemplo o caso de concessão de licença prêmio de seis meses a servidor público, quando o Estatuto prevê apenas três meses, que pode ser reformado retroativamente, considerando-se o período legal $^{20}$.

\subsection{Requisitos da convalidação}

A convalidação é a produção de novo ato, sem vício, que elimina e substitui o ato inválido herdando os efeitos por ele produzidos, tomando-os como seus e fazendo-os sobreviver. Portanto, a convalidação não evita a extinção do ato inválido. Na verdade, ocorre o desfazimento do ato inválido, retirando-lhe sua aptidão de produzir efeitos futuros, mas tal desfazimento não atinge os efeitos passados, decorrentes do ato inválido, porque o novo ato os assume como seus. A validade dos efeitos produzidos pelo ato convalidado passa, juridicamente, a decorrer do ato convalidador.

Diante disso, podemos afirmar que é requisito primordial da convalidação que o ato possa ser reproduzido sem vício e com possibilidade de retroagir.

A repetição do ato deve ser entendida em termos, uma vez que reproduzindo-se um ato idêntico ao anterior, reproduzir-se-á também o vício. Então, reproduzir o ato significa editar um novo ato com idêntico conteúdo.

A possibilidade de retroagir é necessária pois o ato convalidador forma com o ato convalidado uma unidade ${ }^{21}$ herdando seus efeitos ${ }^{22}$.

\footnotetext{
${ }^{20}$ ARAÚJO. Edmir Netto de. Convalidação do ato administrativo. São Paulo: LTr, 1999, p.147

${ }^{21}$ AMARAL, Antonio Carlos Cintra do. Extinção do Ato Administrativo. São Paulo: RT, 1978, p. 65

${ }^{22}$ SUNDFELD, Carlos Ari. Ato administrativo inválido. São Paulo: Revista dos Tribunais, 1990, p. 52
} 
Também é necessário que o novo ato possa ser validamente reproduzido no presente, isto é, “o vício tem de ser tal que, uma vez eliminado, não impeça a prática de novo ato com conteúdo igual ao do anterior",23.

Outro pressuposto da convalidação, comum a todos os atos administrativos, é a necessidade de motivação. A demonstração clara e objetiva das razões que levaram a autoridade administrativa a assim proceder, permitirá a verificação da presença ou não dos demais requisitos da convalidação e seu consequente controle administrativo ou judicial ${ }^{24}$.

É de se lembrar que a Lei 9.784/99, ao enumerar os atos administrativos que deverão ser motivados, reporta-se expressamente àqueles que "importem anulação, revogação, suspensão ou convalidação de ato administrativo" (art. 50, VIII).

\subsection{Atos convalidáveis e atos inconvalidáveis}

Visto os requisitos gerais para que possa haver convalidação, importa saber agora, de forma específica, quais espécies de vícios, possibilitam a reprodução legítima do ato no presente, a fim de distinguir os atos convalidáveis dos inconvalidáveis.

Considerando a sistematização dos vícios que podem incidir sobre os atos administrativos, temos que não podem ser convalidados os atos com vícios de finalidade, de motivo, de conteúdo, de causa e de forma ou procedimento quando este desvirtuar a finalidade do ato, porque não haveria possibilidade de serem repraticados sem os vícios originais. De outro lado, são convalidáveis os atos com vício de competência, de formalidade e de procedimento.

\subsubsection{Atos inconvalidáveis}

\subsubsection{Com vício de finalidade}

Se um ato é praticado visando finalidade diversa daquela prevista legalmente, não há como suprir este vício, pois o desvirtuamento da finalidade estará sempre presente, ainda que se pratique novo ato.

\footnotetext{
${ }^{23}$ Idem, ibidem, p. 52

${ }^{24}$ Idem, ibidem, p. 74
} 
Ao falarmos em vício de finalidade há que se distinguir o vício de finalidade genérica, do vício de finalidade específica.

O vício de finalidade genérica ocorre quando há um desvirtuamento de uma finalidade pública para uma finalidade de interesse privado. É exemplo, a desapropriação realizada objetivando prejudicar o proprietário do imóvel.

O vício de finalidade específica ocorre quando o agente público pratica um ato, embora com finalidade pública esta não é inerente ao conteúdo do ato escolhido. É o caso, por exemplo, da instituição de zona azul para aumentar a arrecadação de determinado município. Tanto a instituição de zona azul como o aumento da arrecadação são de interesse público. Porém, a finalidade da instituição de zona azul é a melhor ordenação do estacionamento em locais de grande circulação de veículos. Assim, se o que se pretende é o aumento da arrecadação, deve-se utilizar instrumentos específicos para tal.

A doutrina é unânime em afirmar que o ato administrativo com vício de finalidade é inconvalidável porque não é possível suprir o vício, uma vez que o desvirtuamento da finalidade estará sempre presente.

Mesmo em caso de desvio de finalidade específica não é possível a convalidação, porque o ato repraticado será outro, com outro conteúdo, adequado a finalidade que se quer atingir.

Weida Zancaner ${ }^{25}$, que também compartilha da mesma opinião, cita o seguinte exemplo: "a finalidade do ato que interdita um prédio sem condições de segurança é a segurança pública. Assim, a interdição de um prédio em condições de uso, por motivos de inimizade política, constitui desvio de finalidade e não pode ser convalidada".

\subsubsection{Com vício de motivo}

Quando a invalidade for causada pela inexistência do motivo justificador da prática do ato, também impossível a convalidação, pois ainda que a circunstância legitimadora ocorra posteriormente, haverá prática de um novo ato administrativo que não guarda conexão com o anterior. Por exemplo, o ato de concessão de aposentadoria compulsória a servidor público antes que o mesmo tenha completado 70 anos, não se convalida com o implemento da idade, uma vez que o novo ato não terá possibilidade de

${ }^{25}$ ZANCANER, Weida. Da convalidação e invalidação dos atos administrativos. $3^{\mathrm{a}}$ ed. São Paulo: Malheiros, 2008, p. 96 
retroagir, pois o servidor só adquiriu o direito a aposentadoria ao completar 70 anos e não antes.

No entanto, sabendo-se que o motivo do ato é a circunstância de fato ou de direito que autoriza ou justifica a prática do ato administrativo, pode ocorrer de a autoridade administrativa indicar erroneamente o dispositivo legal aplicável. Nesta hipótese, entendemos que poderá haver a convalidação, desde que a circunstancia de fato tenha efetivamente ocorrido. Por exemplo: A Administração Pública, necessitando ampliar sua rede viária, edita decreto expropriatório, indicando como fundamento legal a Lei 4.132 (que regulamenta a desapropriação por interesse social) enquanto o correto fundamento seria o Decreto Lei 3365/41 (que trata da desapropriação por utilidade pública). Este ato poderá ser convalidado, retificando-se o fundamento legal, uma vez que a necessidade de ampliação da rede viária existia na época da edição do decreto expropriatório.

\subsubsection{Com vício de conteúdo ou objeto}

Em relação aos vícios incidentes sobre o conteúdo ou objeto do ato há que se distinguir a espécie de vício. Os atos, cujo objeto é ilícito ou impossível não podem ser reproduzidos validamente, pois tantas vezes o forem, o erro se repetirá ${ }^{26}$. Quando a modificação pretendida pela ordem jurídica (conteúdo) é defeituosa, é possível a convalidação, na modalidade de conversão, ou seja, substitui-se o ato vicioso por outro de "anatomia" perfeita".

Carvalho Filho ${ }^{28}$ afirma somente ser possível a convalidação de ato com vício no conteúdo quando este for plúrimo. Assim, quando a vontade administrativa se destinar a mais de uma providencia no mesmo ato, e apenas uma delas estiver viciada, o ato pode ser aproveitado suprimindo ou alterando conteúdo irregular, mantendo-se os demais.

\footnotetext{
${ }^{26}$ ZANCANER, Weida. Da convalidação e invalidação dos atos administrativos. cit, pp. 93-94

${ }^{27}$ SANTOS NETO, João Antunes dos. Da Anulação Ex Officio do Ato Administrativo. Belo Horizonte: Fórum, 2004, p. 179

${ }^{28}$ CARVALHO FILHO, José dos Santos. Manual de Direito Administrativo. 25. ed., São Paulo: Atlas, 2012, p. 164
} 
Para Weida Zancaner ${ }^{29}$, acompanhando as lições de Oswaldo Aranha Bandeira de Mello, este aproveitamento parcial do ato não é propriamente convalidação ou conversão e sim redução.

Entendemos ser possível a convalidação do ato com vício de conteúdo, por meio da conversão, mesmo nos casos em que o objeto for único. Embora se trate de edição de outro ato, diferente do primeiro - porque o conteúdo é outro - aproveitam-se os efeitos do ato inválido e, portanto, pode ser considerado como espécie de convalidação.

\subsubsection{Com vício de causa}

Sendo a causa do ato administrativo a existência de correlação lógica entre o motivo e conteúdo, tendo em vista sua finalidade, este tipo de vício significa um descompasso objetivo entre três elementos do ato que se repetirá toda vez que o ato for reeditado, tornando impossível a convalidação ${ }^{30}$.

Poder-se-ia argumentar que o vício de causa poderia ser suprido com a conversão, ou seja, editando-se novo ato com conteúdo adequado em relação ao motivo e finalidade. No entanto, os efeitos do ato com vício de causa serão outros, não podendo ser reaproveitados, conforme se disse no item anterior. Assim, o ato de remoção do servidor (conteúdo) objetivando puní-lo (finalidade) em razão da prática de infração administrativa (motivo) é ato com vício de causa, pois não possui correlação lógica entre estes três elementos. O efeito deste ato é a alteração do local de trabalho do servidor. E esse efeito não será preservado com a conversão do ato de remoção em um ato punitivo - que seria o adequado ao motivo e finalidade que se quer atingir.

\subsubsection{Com vício de formalidade e de procedimento}

Os atos administrativos com vícios de forma e de procedimento não podem ser convalidados quando a inobservância destes desvirtuar-lhes a finalidade. Disto é exemplo uma contratação pela Administração realizada sem observância do procedimento licitatório quando exigível, ou o ingresso no serviço público para ocupar cargo de provimento efetivo sem o prévio concurso público.

\footnotetext{
${ }^{29}$ ZANCANER, Weida. Op. cit., p. 94

${ }^{30}$ Idem, ibidem, p. 96
} 


\subsubsection{Atos convalidáveis}

\subsubsection{Com vício de competência}

Em relação aos atos praticados com vício de competência há a possibilidade de convalidação, na modalidade de ratificação tanto nas hipóteses em que a emanação de vontade deveria advir de autoridade superior, mas agente subordinado seu a praticou, como em casos de competências materiais díspares, quando, por exemplo, um ato da alçada do Ministro da Saúde é editado pelo Ministro da Educação, ou ainda, quando praticado por pessoas políticas distintas, em que o Presidente da República autoriza o afastamento de servidor municipal e o Prefeito cumpre o ato ${ }^{31}$.

Di Pietro $^{32}$ afirma somente ser possível a ratificação quando não se tratar de competência conferida com exclusividade, ou seja, quando impossível a delegação ou avocação; quando não se tratar de matéria de competência exclusiva das pessoas políticas públicas (União, Estados, Município), ou ainda, quando não se tratar de incompetência em razão da matéria.

Concordamos com Weida Zancaner ${ }^{33}$, que acolhendo ensinamento de Carlos Ari Sundfeld, discorda da distinção entre incompetência absoluta e incompetência relativa utilizada como critério de possibilidade de convalidação, por entender serem os mesmos baseados na distinção entre incapacidade absoluta e relativa nos moldes adotados pelo Código Civil brasileiro e indevidamente transplantados para o caso sub análise. A autora exemplifica, afirmando ser aceitável que o ato de interdição de uma indústria poluente subscrito por um Secretário de Estado incompetente em razão da matéria seja convalidado, posteriormente, pelo Secretario competente.

Mesmo se tratando de competência conferida com exclusividade entendemos ser possível a convalidação, ao contrário do afirmado por Di Pietro. Imaginemos a nomeação de Ministro do Tribunal de Contas da União, cuja competência é exclusiva do Presidente da República (art. 84, Constituição Federal), feita por um Ministro de Estado. Neste caso, o que impediria o Presidente da República de convalidar o ato de nomeação se presentes os requisitos do artigo $73, \S 1^{\circ}$, da Constituição da República? Embora não se possa considerar que seja obrigatória a convalidação, uma vez que se trata

${ }^{31}$ SUNDFELD, Carlos Ari. Ato administrativo inválido. cit., p. 62

${ }^{32}$ DI PIETRO, Maria Sylvia Zanella. Direito Administrativo. cit., 2011, p. 250

${ }^{33}$ ZANCANER, Weida. Da convalidação e da invalidação dos atos administrativos. cit, p. 86 
de ato discricionário, não vemos qualquer óbice para que assim proceda a autoridade competente, aproveitando-se os efeitos do ato produzido anteriormente com vício de competência.

\subsubsection{Com vício de formalidade}

Desde que o vício de formalidade seja tal que não desvirtue a finalidade a ser perseguida pelo ato e não fira direitos dos administrados pode ocorrer a convalidação do ato suprindo-se a formalidade faltante. É exemplo a outorga do direito para construir mediante autorização (ato precário e discricionário), quando o correto seria que tal outorga fosse formalizada por licença (ato vinculado). Nesta hipótese a Administração Pública poderia realizar a conversão substituindo o ato de autorização pelo de licença.

A ausência de motivação, espécie de vício de formalidade, também pode ser sanada pela convalidação sempre que for possível demonstrar, de maneira inequívoca a efetiva ocorrência dos fatos e sua correlação com o ato praticado e desde que não cause cerceamento de defesa ao administrado ou dificuldade de impugnar o ato ${ }^{34}$.

Embora não se trate tecnicamente de convalidação, admite-se também a correção do vício de formalidade, por iniciativa do administrado, quando este promove o implemento das providências faltantes que estejam a seu cargo. Neste caso, ocorre a sanatória, pois não há declaração de vontade da Administração Pública, não se podendo falar em convalidação, conforme já exposto.

\subsubsection{Com vício de procedimento}

A convalidação de ato com vício de requisitos procedimentais só é possível se sua ausência ou falha não comprometer a finalidade da atuação administrativa.

Não importa o momento em que estes vícios são detectados, se antes ou após a emissão do ato final. Caso sejam corrigidos antes da edição do ato final, este será válido e não há que se falar em convalidação. Por outro lado, se o vício de requisito procedimental for detectado posteriormente a emissão do ato final torna-se necessário a restauração da legalidade. Destarte, a Administração Pública verificando que a ausência ou

\footnotetext{
${ }^{34}$ SILVA, Clarissa Sampaio. Limites à invalidação dos atos administrativos. São Paulo: Max Limonad, 2001, p. 130
} 
realização defeituosa do requisito procedimental não gerou desvio de finalidade, deverá proceder à convalidação por meio da prática ou correção do requisito ausente ou equivocado.

A falha quanto ao requisito procedimental também poderá advir do administrado, nos casos em que lhe competia praticá-lo. A sanatória ${ }^{35}$ dependerá da ação do administrado que deverá cumprir o ato ausente, manifestando expressamente sua intenção de fazê-lo retroagir. A título de exemplo, mencione-se o caso em que a Administração concede licença a servidor para tratar de assuntos particulares sem que o mesmo tenha apresentado requerimento. Apresentando-o posteriormente a concessão da licença com expresso pedido de retroação, o ato estará sanado.

Também pode ser citado como exemplo a seguinte situação: a Administração equivocadamente concede licença para construir a um administrado, cujo projeto não atende todas as determinações da legislação edilícia. Tomando conhecimento da irregularidade, e antes que tenha sido iniciada a construção, a Administração notifica-o para que proceda a correção no projeto de forma a atender a legislação. Ao fazê-lo e entregar o projeto corrigido, o ato de licença é sanado.

\subsection{Limites a convalidação}

Há hipóteses em que mesmo diante de vícios sanáveis como os vistos anteriormente, a convalidação não poderá ser efetivada em decorrência de fatores impeditivos.

De acordo com Edmir Netto de Araújo $^{36}$ as hipóteses em que o ato não pode ser convalidado são: a) quando se tratar de ato válido ou de ato inexistente, uma vez que é logicamente impossível tornar válido o que já tem validade, assim como convalidar o que não existe; b) os atos que por sua natureza não podem ser validamente reproduzidos no presente, conforme expusemos no subitem anterior, referentemente aos atos inconvalidáveis; c) quando prescrito o poder-dever da Administração Pública de invalidar ou convalidar; d) quando o ato viciado tiver sido impugnado pelas vias judicial ou administrativa; e) atos que não representem decisões, como os pareceres; f) atos que

\footnotetext{
${ }^{35}$ Utilizamos sanatória, uma vez que adotamos neste trabalho o conceito de convalidação como sendo uma declaração de vontade da Administração Pública no sentido de praticar um novo ato administrativo suprimindo-se o vício do ato originariamente inválido.

${ }^{36}$ ARAÚJO. Edmir Netto de. Convalidação do ato administrativo. cit., p. 135-139
} 
geraram direitos subjetivos ao beneficiário, ou decisões favoráveis ao funcionário em processo administrativo, desde que não verificado dolo por parte do beneficiário.

As hipóteses de ato válido, ato inexistente, atos que não representem decisões e atos que contém vícios insanáveis dispensam maiores comentários. Os primeiros porque a impossibilidade de convalidação decorre de inviabilidade fática e os atos portadores de vícios insanáveis já foram explicitados no item anterior. As questões referentes a prescrição do poder-dever de convalidação, que também são considerados como fator impeditivo à convalidação por diversos autores serão tratadas em capítulo específico deste trabalho.

Procuraremos, então, nos ater aos limites a convalidação sob os quais há divergências doutrinárias.

Alguns doutrinadores ${ }^{37}$ entendem constituir um limite à convalidação, a impugnação do ato pelo particular. A justificativa para tal assertiva é a proteção ao direito do particular de ter sua pretensão (invalidação) atendida, bem como por tornar inútil a arguição do vício, fazendo com que a extinção dos efeitos ilegítimos dependa da vontade da Administração e não de seu dever de obediência à ordem jurídica.

Sérgio Ferraz ${ }^{38}$, acompanhado por Mônica Martins Toscano Simões ${ }^{39}$ entende ser possível a convalidação do ato impugnado e explica que não há inutilidade na arguição do vício pelo particular, pois esta acaba impelindo a Administração a corrigir o vício, restaurando a legalidade. Também discorda do argumento de que a convalidação ofenderia o direito do particular de ver o ato inválido anulado. Explica que o objetivo da impugnação é a desconstituição do ato viciado e/ou a recomposição dos danos por ele causados. Se o ato inválido tem uma finalidade de interesse público, sua convalidação atende ao princípio da supremacia do interesse público não podendo prevalecer o interesse do particular na eliminação do ato. Quanto aos danos, verifica-se que os mesmos podem decorrer tanto do ato viciado como do ato convalidador. Mas, em ambas as hipóteses o particular terá garantido seu direito ao ressarcimento pelos danos sofridos, tendo como

${ }^{37}$ ARAÚJO. Edmir Netto de. Convalidação do Ato Administrativo. cit., p. 136-137; MELLO, Celso Antonio Bandeira. Curso de Direito Administrativo. 17. ed., São Paulo: Malheiros, 2004, p. 433; ZANCANER, Weida. Da convalidação e da invalidação dos atos administrativos. cit., p. 72

${ }^{38}$ FERRAZ, Sergio. "Extinção dos atos administrativos". Revista de Direito Administrativo. Rio de Janeiro, vol. 231, jan. mar. 2003, p. 63

${ }^{39}$ SIMÕES, Monica Martins Toscano. O processo administrativo e a invalidação de atos viciados. São Paulo: Malheiros, 2004, p.145 
fundamento o artigo $37, \S 6^{\circ}$, da Constituição Federal. Sintetiza seu pensamento afirmando:

a impugnação é um dado menor, de interesse egocêntrico, sem a transcendência de interesse público. De fato, tinha e tem sempre a Administração o dever de obediência à ordem jurídica e à legalidade. Se para tanto só é ela 'acordada' pela impugnação, tanto melhor: corrija-se o erro e repare-se o dano que alguém tenha sofrido ${ }^{40}$.

Segundo Pietro Virga ${ }^{41}$, a legislação italiana ${ }^{42}$ prevê expressamente a convalidação também de atos impugnados administrativa ou judicialmente. $\mathrm{O}$ autor explica que tal fato se justifica pela impossibilidade da atuação administrativa ser paralisada ou retardada pela ação de um cidadão. A convalidação, ao contrário da anulação que retira do mundo jurídico o ato inválido, não põe fim a controvérsia, uma vez que mantém o ato apenas eliminando seu vício. Desta forma, cumpre ao cidadão impugnar por meio de outro recurso, o novo ato que visa convalidar o precedentemente impugnado.

Celso Antônio Bandeira de $\mathrm{Mello}^{43}$ também entende constituir óbice a convalidação a impugnação do interessado, acrescentando a esta, a impugnação por resistência. A impugnação por resistência ocorre quando o administrado fazendo um juízo antecipado da ilegalidade do ato, deixa de cumpri-lo. Por isso, a superveniente convalidação do ato tornaria seu descumprimento ilegítimo sujeitando-o a responsabilização.

No entanto, discordamos. Entendemos que mesmo a impugnação por resistência não pode constituir óbice à convalidação do ato. A solução, neste caso, é a mesma que foi dita anteriormente. Se o interesse público determinar a convalidação, estaremos diante de um conflito entre interesse público e privado, devendo prevalecer o primeiro. Seria o caso de aplicação do princípio da confiança legítima impedindo a retroação do ato convalidador para prejudicar terceiros de boa-fé. Se o particular deixou de cumprir $\mathrm{o}$ ato porque este era ilegal, não há justificativa para ser punido com a

\footnotetext{
${ }^{40}$ FERRAZ, Sergio. Op. cit., p. 63

${ }^{41}$ VIRGA, Pietro. Il provvedimentoamministrativo. Milano: Giuffrè Editore, 1972, p. 501

${ }^{42}$ Art. 6 della L. sulriassetto (L. 18 marzo 1968 n. 249)

${ }^{43}$ MELLO, Celso Antonio Bandeira. Curso de Direito Administrativo. 17. ed., São Paulo: Malheiros, 2004, p. 434
} 
convalidação do ato. Ainda mais que com a convalidação ficou comprovada que o ato realmente era inválido. Mas isso não significa que a partir da convalidação o particular continue desobrigado de cumprir o ato. Ele somente não pode ser responsabilizado pelo descumprimento anterior, mas a partir da convalidação, como o ato se tornou legítimo, o seu descumprimento ensejará responsabilização.

O artigo 55 da Lei 9.784/99 que regulamenta o processo administrativo no âmbito federal, ao tratar da convalidação dispõe que: "Em decisão na qual se evidencie não acarretarem lesão ao interesse público nem prejuízo a terceiros, os atos que apresentarem defeitos sanáveis poderão ser convalidados pela própria Administração".

Tomando-se como parâmetro referido dispositivo, podemos concluir que em se tratando de vícios sanáveis a convalidação não poderá ser realizada quando houver lesão a interesse público e prejuízo a terceiros.

Entretanto, entendemos que tal dispositivo deva ser interpretado com ressalva quanto a inexistência de lesão ao interesse de terceiros. Uma coisa é o ato de convalidação não causar ofensa ao interesse público e, outra, bem diferente, é a existência de um interesse público que imponha a convalidação. Neste caso, o prejuízo a terceiros não obstará a convalidação pois estaremos diante de um "conflito" entre interesse público e interesse particular em que deverá prevalecer o interesse coletivo, cumprindo a Administração recompor o prejuízo causado ao particular por meio de indenização.

Weida Zancaner ${ }^{44}$ aponta, ainda, como fatores impeditivos a convalidação, além da impugnação do interessado, o decurso do tempo.

Para Mônica Martins Toscano Simões ${ }^{45}$, com quem concordamos, o decurso do tempo não constitui barreira a convalidação, uma vez que não há qualquer previsão legal, seja no âmbito federal (Lei 9.784/99) ou Estadual (Lei paulista 10.177/98) de prazo decadencial para convalidação. Referidas leis somente impõe óbice temporal para invalidação, o que permite concluir que, diante de vícios sanáveis e não se constatando nenhum fator impeditivo à convalidação esta possa ser realizada a qualquer tempo.

\footnotetext{
${ }^{44}$ ZANCANER, Weida. Da convalidação e da invalidação dos atos administrativos. $3^{\mathrm{a}}$ ed. São Paulo: Malheiros, 2008, p. 72-73

${ }^{45}$ SIMÕES, Monica Martins Toscano. O processo administrativo e a invalidação de atos viciados. São Paulo: Malheiros, 2004, p. 130, 146
} 


\subsection{Obrigatoriedade ou faculdade de convalidação}

O princípio da autotutela combinado com o princípio da eficiência determina que tão logo a Administração Pública tenha conhecimento de uma atuação ilegal, deva instaurar o procedimento administrativo visando a correção de tal ilegalidade de forma a restaurar a legalidade.

Conforme visto em capítulo anterior, é possível a restauração da legalidade tanto pela anulação como pela convalidação. E considerando o caráter vinculado da autotutela, é possível concluir ser a anulação e a convalidação obrigatórias.

Muito se discute acerca da prevalência ou não da convalidação sobre a anulação, ou seja, parte da doutrina e jurisprudência entendem que estando presentes os pressupostos da convalidação, este obrigatoriamente deverá ser o procedimento escolhido pela Administração para restaurar a legalidade. De outro lado, estão os que acreditam não existir referida obrigatoriedade, devendo o administrador, diante das peculiaridades do caso concreto, optar pela alternativa que melhor atenda ao interesse público.

Para Weida Zancaner ${ }^{46}$ a convalidação deve prevalecer sobre a anulação, uma vez que milita a favor daquela (convalidação) além do princípio da legalidade, o principio da segurança jurídica. Assim, sintetiza:

quando possível a convalidação dos atos viciados, a Administração não poderá negar-se a fazê-lo. Não há, nesta hipótese - repita-se -, opção discricionária, pois, se a Administração deve agir com fiel subsunção à lei, não nos parece plausível que possa ficar a critério do administrador invalidar atos, relações jurídicas ou ambos se existe a possibilidade de convalidá-los, pois a convalidação atende não só ao princípio da legalidade mas, sobretudo, ao da segurança jurídica, ressalvada a hipótese de ato discricionário maculado por vício de competência.

Tese diversa parece ter sido adotada no direito positivo, nos termos do artigo 55, da Lei 8.987/99 e do art. 11, da Lei Paulista 10.177/98 que utilizam a expressão poderão ser convalidados e poderá convalidar, respectivamente.

\footnotetext{
${ }^{46}$ ZANCANER, Weida. Da convalidação e da invalidação dos atos administrativos. $3^{\mathrm{a}}$ ed. São Paulo:
} Malheiros, 2008, p. 68 
Comentando tais dispositivos, Celso Antônio Bandeira de Mello ${ }^{47}$ afirma padecerem os mesmos de vício de inconstitucionalidade, pois adotam diretriz que contraria princípios gerais de Direito, que no caso em questão é o da segurança jurídica. Explica o autor:

Quando em um tema especifico dois princípios jurídicos de estatura constitucional concorrem em prol de uma solução (na hipótese vertente, o da restauração da legalidade - que a convalidação propicia, como visto e o da segurança jurídica), o legislador infraconstitucional não pode ignorá-los e adotar diretriz que os contrarie, relegando a plano subalterno valores que residem na estrutura medular de um sistema normativo.

O autor deixa claro que a única maneira de se garantir a segurança jurídica, diante de atos inválidos - que comportam convalidação - é através da convalidação. Entretanto, verifica-se que o princípio da segurança jurídica é cabalmente atendido, pela prevalência de critérios objetivos sobre os subjetivos na opção entre convalidar e anular, assim como pelo dever de motivação do ato ${ }^{48}$.

Sérgio Ferraz ${ }^{49}$, para quem a convalidação também deve prevalecer sobre a anulação acrescenta que a flexão verbal poderão utilizada pelo art. 55, da Lei $8.987 / 99$ significa

a expressa atribuição de um poder-dever: expressa, porque dá letra de forma ao que sempre existiu, mesmo antes da aludida lei; poder-dever (ou, ainda melhor, dever poder), porque a convalidação é emanação direta dos princípios da legalidade, segurança jurídica e supremacia do interesse público, não remanescendo, destarte, margem de escolha, para o agente administrativo.

${ }^{47}$ MELLO, Celso Antonio Bandeira. Curso de Direito Administrativo. 17. ed. São Paulo: Malheiros, 2004, p. 437

${ }^{48}$ MOTTA, João Francisco da. Invalidação dos atos administrativos. Belo Horizonte: Del Rey, 2010, p. 114

${ }^{49}$ FERRAZ, Sergio. "Extinção dos atos administrativos". cit., p. 63 
Edmir Netto de Araújo ${ }^{50}$, antes do advento das leis comento, já adotava posicionamento no sentido de existir discricionariedade na opção entre convalidar e invalidar. Para ele

não há propriamente um dever de convalidar o ato anulável, mas o dever de recompor a legalidade ferida, o que se faz tanto fulminando o ato viciado quanto convalidando-o, e esta opção, como se viu, é discricionariamente voltada à melhor solução para o Direito, com vistas ao cumprimento do fim específico de interesse público do ato em revisão, pois o fim especial do novo ato é o resguardo da ordem jurídica.

Miguel Reale ${ }^{51}$ ao afirmar que desde que se não firam legítimos interesses de terceiros ou do Estado e inexista dolo, a Administração pode deixar de decretar a nulidade do ato ou optar pela convalidação também concorda haver discricionariedade nesta escolha.

Seabra Fagundes ${ }^{52}$, embora não admita de forma expressa a possibilidade de convalidação, ao justificar sua opinião no sentido da impossibilidade de transplantar para o Direito Administrativo a classificação das nulidades elaboradas pelo Direito Civil, nos concede importante subsídio para concluir que a opção entre convalidar ou anular depende de uma ponderação de valores, diante do caso concreto. $\mathrm{O}$ autor assevera que

a infringência legal no ato administrativo, se considerada abstratamente, aparecerá sempre como prejudicial ao interesse público. Mas, por outro lado, vista em face de algum caso concreto, pode acontecer que a situação resultante do ato, embora nascida irregularmente, torne-se útil àquele mesmo interesse. Também as numerosas situações pessoais alcanças e beneficiadas pelo ato vicioso podem aconselhar a subsistência dos seus efeitos.

\footnotetext{
${ }_{50}^{50}$ ARAÚJO. Edmir Netto de. Convalidação do ato administrativo. cit., p. 135

${ }^{51}$ REALE, Miguel. Revogação e Anulamento do Ato administrativo. 2. ed. Rio de Janeiro: Forense, 1980, p. 63

${ }^{52}$ FAGUNDES, Miguel Seabra. O controle dos atos administrativos pelo Poder Judiciário. 5. ed. Rio de Janeiro: Forense, 1979, p. 47
} 
Ora, a presunção de que a invalidade do ato administrativo fere o interesse público é relativa, pois diante das circunstâncias do caso concreto poderá ser verificado um interesse público maior que justifique a manutenção dos efeitos produzidos pelo ato inválido. Assim, não se pode afirmar que a invalidação com a consequente desconstituição dos efeitos produzidos seja sempre a melhor solução, ou a que melhor atenderá o interesse público. Pelas mesmas razões, pode-se considerar relativa a presunção de que a convalidação, abstratamente considerada melhor atende o interesse público, por contemplar além do principio da legalidade o da segurança jurídica. Somente diante do caso concreto será possível ao administrador avaliar qual a melhor solução: anulação ou convalidação.

É este também o posicionamento adotado por Sundfeld ${ }^{53}$ que afirma não existir, a priori, dever de convalidação, que pode, entretanto, surgir face às peculiaridades do caso concreto.

Juarez Freitas ${ }^{54}$, ao discorrer sobre o controle judicial dos atos administrativos afirma que este somente será bem sucedido se o julgador proceder a uma ponderação entre os princípios aparentemente em conflito, considerando o caso concreto.

Estamos entre os que consideram que a opção entre convalidar ou anular encontra-se no âmbito da discricionariedade do administrador. Somente este, em contado com a realidade é capaz de avaliar, analisando as peculiaridades do caso concreto, qual a melhor solução.

Pode-se dizer, que existe discricionariedade na escolha do modo que se restabelece a legalidade (convalidação ou anulação), e vinculação no restabelecimento da legalidade. O administrador, diante de uma situação ilegal, não poderá ficar inerte. Tem obrigatoriedade de agir a fim de restaurar a legalidade, adotando uma ou outra solução.

${ }^{53}$ SUNDFELD, Carlos Ari. Ato administrativo inválido. cit., p. 75

${ }^{54}$ FREITAS, Juarez. O controle dos atos administrativos e os princípios fundamentais. 2. ed., São Paulo: Malheiros Editores, 1999, p. 44 


\section{PRESCRIÇÃO E DECADÊNCIA}

\subsection{Limite temporal à autotutela da Administração Pública}

O decurso do tempo gera consequências nas relações jurídicas, podendo ocasionar a extinção ou aquisição de direitos, o cumprimento de punições e, às vezes, sem que haja a perda do direito, perde-se a possibilidade de exercitá-lo por meios próprios ${ }^{1}$.

A autotutela da Administração Pública assim entendida como o "poder de prover pelos próprios meios, e de modo coercitivo a situações de efetiva ou potencial lesão à ordem jurídica ou ao interesse público" ${ }^{2}$, também é limitada pelo decurso do tempo. Este período, após o qual a Administração Pública perde seu direito de rever seus próprios atos, pode ou não estar previsto em lei.

O fato de não haver previsão do prazo em lei não significa que a Administração possa exercer a autotutela a qualquer tempo. A sua inércia pode conduzir à consolidação de situações de fato, cuja preservação pode atender melhor ao interesse da coletividade, contemplando o princípio da segurança jurídica.

Portanto, mesmo não havendo prazo expressamente definido em lei, a Administração Pública encontra-se, regra geral, limitada pelo tempo em seu direito de rever seus atos.

A prescrição, como se sabe, é a perda da pretensão (ou seja, do direito de buscar judicialmente o reconhecimento de um direito). Já a decadência é a perda do direito em si, em razão do seu não exercício num determinado período de tempo.

Carnelutti $^{3}$ diferencia os dois institutos explicando que

\footnotetext{
A prescrição é conceito que não pertence, ao contrário da decadenza, à estática, mas à dinâmica do direto, o mesmo acontecendo com a perempção. Ao passo que a decadenza é expressão da inexistência de uma situação (ativa), a prescrição e a perempção são expressão de um fato ou, com mais precisão, de uma omissão prolongada no tempo (por

${ }^{1}$ ARAÚJO. Edmir Netto de. Convalidação do Ato Administrativo. São Paulo: LTr, 1999, p. 148

${ }^{2}$ MOTTA, João Francisco da. Invalidação dos atos administrativos. Belo Horizonte: Del Rey, 2010, p. 91

${ }^{3}$ CARNELUTTI, Francesco. Teoria Geral do Direito. Tradução de Antônio Carlos Ferreira. São Paulo: Lejus, 1999, p. 494
} 
um certo tempo). Assim se esclarece o princípio familiar aos práticos, segundo o qual tanto a prescrição como a perempção admitem suspensão e interrupção, não admitidas na decadenza. Importa quanto a esta que um poder se exerça numa certa distantia temporis; à prescrição e à perempção, diversamente, importa que uma omissão tenha uma certa duração.

A pretensão diz respeito à possibilidade de se exigir da outra parte o cumprimento de um dever jurídico. Portanto, pode-se dizer que a pretensão deve corresponder a uma contraprestação da outra parte. A prescrição, repita-se, implica na perda apenas da pretensão, não alcançando o direito em si. Desta forma, se o devedor, mesmo prescrita a pretensão executória, espontaneamente cumpre a obrigação, não poderá depois exigir o reembolso da quantia paga. Porque o direito ao crédito persistiu. Apenas a pretensão ao exercício da ação executória é que se esvaiu.

A Administração Pública, como consequência do seu poder de autotutela, tem o direito de anular seus próprios atos ou então pleitear a anulação perante o Poder Judiciário.

O exercício desse direito, no entanto, deve ocorrer num determinado espaço de tempo. Transcorrido esse tempo, pode ocorrer a perda do direito ou da pretensão a ele relativa. No primeiro caso, por força da decadência. No segundo, da prescrição.

Edmir Netto de Araújo ${ }^{4}$, depois de fazer referência a uma "prescrição externa, ou judiciária, que é válida para obstar a revisão, de qualquer ato jurídico em qualquer sede, inclusive a dos atos administrativos pelo Judiciário ou até pela própria administração", prossegue dizendo que "Não havendo ação, a prescrição não faz desaparecer a nulidade, mas assegura os efeitos dos atos eivados da nulidade, que se produziram ao longo do tempo", refere-se, por último, à "assim chamada prescrição administrativa, na realidade caso de decadência, ou mesmo preclusão, porque sendo a prescrição a perda do direito de ação para provocar a correção, a decadência importa na perda do próprio direito material pelo decurso do prazo que a lei fixou para sua existência".

\footnotetext{
${ }^{4}$ ARAÚJO. Edmir Netto de. Op. cit., p. 148-149.
} 
Desta forma, quando se fala em prazo para anulação de atos administrativos, a referência é ao prazo decadencial (ou prescrição administrativa, como dizem alguns autores) e não prescricional. Assim, o prazo previsto no art. 54, da Lei 9784/99, é decadencial, pois o texto fala que o direito da Administração anular seus próprios atos "decai” em cinco anos. Já a Lei que disciplina o processo administrativo no âmbito do Estado de São Paulo (Lei 10.177 de 30 de dezembro de 1998) limita-se a definir o prazo em dez anos, contados da sua produção, para anulação de seus próprios atos. Não faz qualquer referência à natureza jurídica desse prazo. Porém, diante do que já se expos, esse prazo deve ser tido mesmo como decadencial.

Isso não significa que a Administração não se submeta a prazo prescricional para pleitear anulação do ato administrativo. Isso ocorre sempre que se escoa o prazo decadencial para o exercício da autotutela. Não a exercendo no prazo legal, e desde que não decorrido o prazo prescricional, a Administração poderá obter a anulação perante o Poder Judiciário.

\subsubsection{Decadência do poder de recompor a legalidade: regra ou exceção?}

A concepção de que os atos nulos não se convalescem com o tempo encontra-se superada ou em vias de superação tanto na doutrina como na jurisprudência. Primeiramente, porque ao se mencionar simplesmente ato nulo, não é possível identificar, conforme visto em capítulo anterior, qual o critério utilizado para se considerá-lo tal, uma vez que existem diversas posições doutrinárias sobre o tema. Mas a principal razão é que a ideia da imprescritibilidade é incompatível com a segurança jurídica, princípio basilar do Estado de Direito.

Vem a lume, então, a necessidade de saber se a imprescritibilidade é regra ou exceção. Em outras palavras, se pode ser presumida diante da falta de previsão legal.

Se for regra geral, obviamente a exceção (prescritibilidade) haverá de estar expressamente prevista em lei. Se, ao contrário, a prescritibilidade for a regra geral, a imprescritibilidade é que deverá estar expressa em lei. 
Odete Medauar ${ }^{5}$ perfilha entendimento de que a regra é a imprescritibilidade afirmando que

\begin{abstract}
Limitação temporal ao poder de anular deve estar prevista de modo explícito e não presumido ou deduzido de prazos prescricionais fixados para outros âmbitos. Entendimento diverso traz subjacente incentivo à prática de ilegalidade, ante a possibilidade de ser consolidada pela prescrição.
\end{abstract}

Em sentido contrário, João Francisco da Motta ${ }^{6}$, com quem concordamos, sustenta que a regra é a prescritibilidade. A imprescritibilidade é que constitui exceção.

Esse entendimento encontra seu fundamento principal no princípio da segurança jurídica. Via de consequência, não havendo disposição expressa sobre a prescritibilidade, esta deve ser presumida. De fato, o princípio da segurança jurídica não se coaduna com a incerteza decorrente da inexistência de um lapso temporal para a consolidação da relação jurídica.

Por esta razão, não pode a autoridade administrativa justificar sua inércia em invalidar sob o pretexto de ser ilimitado seu prazo, alegando inexistência de lei dispondo a respeito. A autoridade deverá, suprindo a lacuna da lei, valer-se da interpretação de textos legais e da analogia para determinar o prazo decadencial.

Em contraposição ao argumento de Odete Medauar, no sentido de que a prescritibilidade como regra geral importa em incentivo à prática da legalidade, o autor propõe uma solução: nos casos de autêntica imprescritibilidade (art. 37, § $5^{\circ}$ e art. 191, parágrafo único da Constituição Federal e casos de grave ofensa ao princípio da moralidade administrativa), considera-se "ilimitado apenas o prazo para a identificação do vício, encontrando-se o administrador, a partir deste momento, obrigado à invalidação ou convalidação do ato em lapso temporal reduzido",7.

Embora concordemos com o autor no sentido que a imprescritibilidade não pode ser presumida, prima facie, na ausência de disposição legal, em atenção ao princípio

\footnotetext{
${ }^{5}$ MEDAUAR, Odete. Direito Administrativo Moderno. $10^{\mathrm{a}}$ ed. São Paulo: Revista dos Tribunais, 2006, p. 158

${ }^{6}$ MOTTA, João Francisco da. Invalidação dos atos administrativos. Belo Horizonte: Del Rey, 2010, p. 150

${ }^{7}$ Idem, ibidem, p. 150
} 
da segurança jurídica, esta solução não nos parece a mais adequada, porque além de não indicar qual prazo teria o administrador para promover a invalidação ou convalidação do ato, haveria afronta a dispositivo constitucional. Ainda que se estabeleça, por analogia, um prazo razoável para a autoridade administrativa promover a restauração da legalidade após a ciência do vício maculador do ato administrativo, a impossibilidade de anulação do ato imposta como consequência da omissão da autoridade competente viola os dispositivos constitucionais que tratam expressamente da imprescritibilidade, como os arts. $37, \S 5^{\circ}$, $183, \S 3^{\circ}$ e 191 da Constituição Federal.

Celso Antônio Bandeira de $\mathrm{Mello}^{8}$ rejeita a tese de imprescritibilidade com uma única ressalva: das ações para ressarcimento de prejuízos causados ao erário, previsto no art. $37, \S 5^{\circ}$, da Constituição Federal. Segundo ele

\begin{abstract}
O estado de pendencia eterna parece-nos incompatível com o objetivo nuclear da ordenação jurídica, que é a ordem, a estabilidade. Tal imprescritibilidade só pode ocorrer, por estar constitucionalmente implicada no art. $37, \S 5^{\circ}$, quando se trate de ações para ressarcimento de prejuízos causados ao erário.
\end{abstract}

Weida Zancaner $^{9}$ defende a imprescritibilidade quando se trate de controle de legalidade dos atos administrativos restritivos dos direitos dos administrados. Para ela “os atos restritivos de direitos são sempre passíveis de invalidação pela Administração, ao menos em relação àquele ou àqueles que tiveram suas esferas jurídicas restringidas ou aviltadas pelo ato inválido".

Compartilhando o mesmo entendimento, João Francisco da Motta ${ }^{10}$ justifica que em se tratando de atos inválidos restritivos de direitos, o decurso do tempo "não atenua - muito ao contrário agrava - a ilegalidade e a lesão".

É certo que o princípio da segurança jurídica informa todo o Estado de Direito. Porém, seu valor não é absoluto. Em se tratando de atos inválidos restritivos de direitos, deve-se ponderar o princípio da segurança jurídica - que levaria à impossibilidade de invalidação - com o principio da moralidade - que justifica a imprescritibilidade, e

${ }^{8}$ MELLO, Celso Antonio Bandeira. Curso de Direito Administrativo. 17. ed.,São Paulo: Malheiros, 2004

${ }^{9}$ ZANCANER, Weida. Da convalidação e da invalidação dos atos administrativos. $3^{\mathrm{a}}$ ed. São Paulo: Malheiros, 2008, p. 64

${ }^{10}$ MOTTA, João Francisco da. Invalidação dos atos administrativos. cit., p.153 
portanto, a possibilidade de anulação do ato, com a consequente interrupção da lesão do direito do administrado, devendo prevalecer este último, obstando-se o convalescimento dos atos restritivos de direitos.

Porém, há uma exceção, em que prevalece a segurança jurídica e, portanto, não se pode invalidar o ato: quando a invalidação de ato restritivo de direito causar prejuízos a terceiros, ou seja, quando a restrição ao direito de alguém corresponder à ampliação de direito de outrem ${ }^{11}$. É o caso, por exemplo, de invalidação de ato de desclassificação de licitante, cuja proposta seria vencedora, após adjudicação e longo tempo de execução do contrato por outro licitante que, não fosse o erro cometido pela Administração, seria o segundo colocado. Aqui, estaria impedida a Administração de promover tal anulação, pois resultaria em prejuízo ao terceiro (licitante) de boa-fé, que em nada concorreu com a ilegalidade.

A prescritibilidade é informada pelo princípio da segurança jurídica, e a imprescritibilidade encontra seu fundamento no princípio da moralidade. Considerando-se o princípio da segurança jurídica como um supra princípio, uma vez que informa todo o Estado de Direito, pode-se concluir que o mesmo, como regra, tem prevalência sobre os demais. No entanto, a situação poderá mudar diante do caso concreto, com prevalência do princípio da moralidade.

\subsubsection{Prazos decadenciais}

Não é suficiente concluir que na ausência de disposição expressa, a prescritibilidade é a regra. Indispensável que se estabeleçam parâmetros que permitam fixar os limites temporais para a anulação.

Weida Zancaner ${ }^{12}$ entende que para anulação do ato convalidável (absolutamente sanável e relativamente sanável), aplica-se o prazo de cinco anos, por analogia ao prazo estabelecido pela Lei 4.717/1965 e pelo Decreto 20.910/1932. Em relação aos atos relativamente insanáveis, a autora subdivide-os em atos ampliativos de direitos e restritivos de direitos. Assim, em relação aos atos ampliativos de direito, em que o beneficiário esteja de boa-fé, também incide o prazo decadencial de cinco anos, por analogia à Lei 9.784/99. Já sobre os atos ampliativos de direitos cujos destinatários tenham

\footnotetext{
${ }^{11}$ Idem, ibidem, p. 154

12 ZANCANER, Weida. Da convalidação e da invalidação dos atos administrativos. cit., p. 110-117
} 
agido com má-fé, incide o prazo de 10 anos, por analogia ao prazo prescricional previsto no Código Civil, considerando-se a necessidade de estabilização das relações jurídicas. Em se tratando de atos restritivos de direitos, que examinaremos em seguida, a Administração pode anulá-los a qualquer tempo.

Adota o mesmo posicionamento Carlos Ari Sundfeld ${ }^{13}$ afirmando que

a invalidação dos atos inconvalidáveis pode ser feita por prazo longo e a dos convalidáveis por prazo curto. O prazo mais dilatado previsto no Código Civil é o de $20 \operatorname{anos}^{14}$, estipulado para a prescrição das ações pessoais (art. 177), e que servirá para a invalidação dos atos inconvalidáveis. Quanto aos convalidáveis, parece-nos adequado acolherse como regra o prazo de cinco anos, por analogia com o Dec. 20.910/32 e Lei $4.717 / 65$.

Celso Antônio Bandeira de Mello ${ }^{15}$ que adotava mesma posição - prazos curtos para atos convalidáveis e longos para atos inconvalidáveis, nos termos da lei civil - , alterou seu entendimento, sob o fundamento de que os princípios informadores das relações de direito privado são tão profundamente distintos dos que inspiram as relações de Direito Público que não seria coerente buscar inspiração em regras de direito civil.

Reforçando tal entendimento Hely Lopes Meirelles ${ }^{16}$ afirma que

\begin{abstract}
A analogia admissível no campo do Direito Público é a que permite aplicar o texto da norma administrativa a espécie não prevista, mas compreendida no seu espírito; a interpretação extensiva, que negamos possa ser aplicada ao Direito Administrativo, é a que estende um entendimento do Direito Privado, não expresso no texto administrativo, nem compreendido no seu espírito, criando norma administrativa nova.
\end{abstract}

\footnotetext{
${ }^{13}$ SUNDFELD, Carlos Ari. Ato administrativo inválido. São Paulo: Revista dos Tribunais, 1990, p. 91.

${ }^{14}$ Percebe-se que o autor refere-se ao Código Civil de 1916, uma vez que o Código em vigor, no art 205 estabelece o prazo prescrional geral de 10 anos.

${ }^{15}$ MELLO, Celso Antonio Bandeira. Curso de Direito Administrativo. cit., p. 930-932

${ }^{16}$ MEIRELlES, Hely Lopes. Direito Administrativo Brasileiro. 25. ed. São Paulo: Malheiros, 2000, p.4849.
} 
Assim, analisando o tratamento atribuído à prescrição e à decadência em regras genéricas de Direito Público, Celso Antônio Bandeira de Mello ${ }^{17}$ conclui ser uma constante o prazo de cinco anos ${ }^{18}$, não havendo diferenciação para fins de prescrição entre atos nulos e anuláveis.

Diante disso, o autor afirma que, na ausência de regra específica, o prazo para Administração invalidar seus atos ampliativos de direitos, em que seus beneficiários estejam de boa-fé, ou insurgir-se contra eles judicialmente, é de cinco anos. Em casos de comprovada má-fé de qualquer uma das partes da relação jurídica, reconhece não haver outra alternativa, senão a de socorrer-se, por analogia ao direito privado, ao prazo de 10 anos (art. 205 do Código Civil).

Maria Sylvia Zanella di Pietro ${ }^{19}$ entende que, salvo disposição legal expressa, a prescrição administrativa deve coincidir com a prescrição judicial, ou seja, cinco anos, independentemente se o ato for nulo ou anulável. Isso porque a possibilidade de revisão do ato após prescrição judicial constituiria ofensa à estabilidade das relações jurídicas que o legislador quis proteger com a fixação de prazo prescricional.

Almiro do Couto e Silva ${ }^{20}$ também entende que embora o prazo previsto pelo art. 54 da Lei n. 9.784/99 não se aplique às demais entidades da federação, deve servir como parâmetro na ausência de regra expressa. Assim, percebe-se que é favorável a aplicação do prazo decadencial de cinco anos.

O Superior Tribunal de Justiça também tem entendimento de que na ausência de regra específica acerca do prazo decadencial para Administração Pública invalidar seus atos aplica-se, por analogia ao art. 54 da Lei 9.784/99, o prazo de cinco anos:

\footnotetext{
${ }^{17}$ MELLO, Celso Antonio Bandeira. Op. cit., p. 930-932

${ }^{18}$ É de cinco anos o prazo prescricional de ações do administrado contra o Poder Público (Dec. 20.910/32 e art. 21 da Lei 4.717/65), de ações do Poder Público contra o administrado para cobrança de débito tributário (art. 174, CTN), o prazo decadencial para constituir o crédito tributário (art. 173, CTN), o prazo prescricional da ação punitiva da Administração Pública Federal, direta e indireta, no exercício do poder de polícia, objetivando apurar infração à legislação em vigor (art. $1^{\circ}$, Lei 9.873/99), o prazo decadencial para Administração Pública invalidar seus próprios atos, dos quais hajam decorrido efeitos favoráveis ao administrado, salvo comprovada má-fé (art. 54, Lei 9.784/99).

${ }^{19}$ DI PIETRO, Maria Sylvia Zanella. Direito Administrativo. 26. ed., São Paulo: Atlas, 2013, p. 810

${ }^{20}$ SILVA, Almiro do Couto e. "Princípios da legalidade da administração pública e da segurança jurídica no estado de direito contemporâneo". Revista de Direito Público. São Paulo, vol. 84, p. 46-63, out-dez/1987, p.44
} 
ADMINISTRATIVO. SERVIDOR PÚBLICO. FILHA SOLTEIRA MAIOR DE 21 ANOS. DEPENDÊNCIA. ASSISTÊNCIA MÉDICOHOSPITALAR. INÉRCIA DA ADMINISTRAÇÃO. DECADÊNCIA ADMINISTRATIVA.

1. Não pode o administrado ficar sujeito indefinidamente ao poder de autotutela do Estado, sob pena de desestabilizar um dos pilares mestres do Estado Democrático de Direito, qual seja, o princípio da segurança das relações jurídicas. Assim, no ordenamento jurídico brasileiro, a prescritibilidade é a regra, e a imprescritibilidade exceção.

2. Na ausência de lei estadual específica, a Administração Pública Estadual poderá rever seus próprios atos, quando viciados, desde que observado o prazo decadencial de cinco anos. Aplicação analógica da Lei n. 9.784/99.

3. Recurso Especial não conhecido. (grifo nosso) ${ }^{21}$

\subsubsection{Exceções à incidência de prazo decadencial sobre poder de rever os} atos administrativos ilegais

Fundamentado no princípio da segurança jurídica, conforme visto no item anterior, temos que a incidência de prazo decadencial para rever atos administrativos ilegais é a regra. Portanto, na ausência de disposição legal expressa, a autoridade administrativa deve suprir a lacuna da lei utilizando-se dos recursos interpretativos cabíveis para estabelecer o prazo.

No âmbito federal, o caput do art. 54, da Lei 9.784/99, estabelece o prazo de cinco anos para Administração invalidar atos ampliativos de direito, desde que não praticados com má-fé.

Interpretando-se a ressalva feita na parte final do art. 54 - salvo comprovada má-fé - é possível sustentar que atos ampliativos de direito dos destinatários praticados com má-fé poderiam ser invalidados pela Administração Pública a qualquer tempo.

Embora o referido art. 54, não explicite se a má-fé a que alude é do destinatário do ato ou do agente que o praticou, considerando-se o princípio da proteção à

${ }^{21}$ STJ, Resp 628.524-RS, Rel. Min. Laurita Vaz, Quinta Turma, DJ: 23/08/2004 
confiança, parece-nos que o dispositivo refere-se ao destinatário do ato. É a sua confiança na legalidade do ato que é protegida. Como diz Almiro do Couto e Silva "a boa-fé a que alude o preceito, quer significar que o destinatário não tenha contribuído, com sua conduta, para a prática do ato administrativo ilegal".

No entanto, esta conclusão - imprescritibilidade quando houver comprovada má-fé do destinatário do ato - tem suscitado controvérsias doutrinárias.

Weida Zancaner ${ }^{23}$ entende ser a imprescritibilidade do direito de invalidar incompatível com a primazia da ordem jurídica e afirma que na "ausência de prazo decadencial para o saneamento desse tipo de ato inválido na Lei 9.784/99 não torna imprescritível referido direito". Para ela, deve-se considerar, por analogia, o prazo previsto pelo art. 205 do Código Civil, ou seja, 10 anos.

João Francisco da Motta $^{24}$ discorda dessa solução, entendendo que em casos de comprovada má-fé, a incidência do prazo decadencial do art. 54 da Lei 9.784/99 deve ser computado a partir da data em que detectada a fraude ou má-fé, por ser esta solução mais adequada ao atendimento do interesse público.

Régis Fernandes de Oliveira ${ }^{25}$ entende não haver prazo para que se anule qualquer ato, pouco importando se nulo ou anulável. Afirma que a aplicação do prazo do Código Civil justifica-se para aqueles que inadmitem a existência de lacuna no sistema normativo. $\mathrm{O}$ autor, por acreditar na possibilidade de existência de lacunas, entendidas estas como uma inadequação entre o sistema normativo e as realidades empíricas, diz que:

Surgida uma questão, chamada no pensamento aristotélico dialético de
problema, o jurista deverá discuti-lo, para buscar uma solução. Parte,
então da tópica valendo-se de qualquer tipo de argumentação, embora
não necessariamente silogístico e dedutivo, e, após estudado, dá-lhe uma
solução. Esta pode não se encontrar no sistema das normas, mas as
próprias normas deverão habilitar o julgador a dar solução não prevista,

${ }^{22}$ SILVA, Almiro do Couto e. "O princípio da segurança jurídica (proteção à confiança) no direito público brasileiro e o direito da Administração Pública de anular seus próprios atos administrativos: o prazo decadencial do art. 54 da Lei do Processo Administrativo da União (Lei 9.784/99)". Revista Eletrônica de Direito do Estado, Salvador, Instituto de Direito Público da Bahia, n. 2, abril/maio/junho, 2005. Disponível na Internet: [http://www.direitodoestado.com.br]. Acesso em 12 de março de 2013, p. 38

${ }^{23}$ ZANCANER, Weida. Da convalidação e da invalidação dos atos administrativos. cit., p. 79

${ }^{24}$ MOTTA, João Francisco da. Invalidação dos atos administrativos. cit., p. 173

${ }^{25}$ OLIVEIRA, Regis Fernandes de. Ato administrativo. 5. ed., São Paulo: Revista dos Tribunais, 2007, p. 152 
seja pelo argumento a simili, seja pelo argumento a contrario. Se pelo primeiro, estaremos defronte da redução do problema ao sistema das normas. Se pelo segundo, afasta-se da subsunção ao esquema seletivo previsto na hipótese da norma e a solução estará na habilitação ao juiz para qualificar deonticamente o comportamento não previsto. Então, entenderá imprescritível o reconhecimento da invalidade dos atos administrativos.

Corrobora com este entendimento a jurisprudência do Superior Tribunal de Justiça.

A favor da imprescritibilidade da autotutela, no caso de má-fé, a Ministra Laurita Vaz, relatora do REsp 591.660/RJ ${ }^{26}$, em que se pleiteava o reconhecimento do prazo prescricional quinquenal previsto no art. 201, do Decreto-lei 89.312/84 para revisão do benefício previdenciário concedido, asseverou que

A revisão de benefício previdenciário, especialmente na hipótese de constatação de fraude, pode ser realizada pela Administração, a qualquer tempo, não se aplicando o prazo do art. 207 do Decreto-Lei 89.312/84, pois "a revisão do processo de aposentadoria efetuada pelo INSS não consubstancia mera faculdade, mas um poder-dever da autoridade pública competente, no zelo pelo erário público e pela lisura dos procedimentos administrativos. (REsp 286.639/SC, Sexta Turma, rel. Min. FERNANDO GONÇALVES, DJ de 25/06/01)

No mesmo sentido o acórdão proferido no $\mathrm{MS} 15.457 / \mathrm{DF}^{27}$, rel. Ministro Castro Meira, em cuja ementa assentou-se que

[...] o mero decurso do prazo de 5 (cinco) anos não tem o condão, por si, de obstar que a Administração Pública revise determinado ato, haja vista que a ressalva constante do art. 54, parte final do caput, da Lei $\mathrm{n}^{\circ}$

${ }^{26}$ REsp 591.660/RJ, Quinta Turma, rel. Min. Laurita Vaz, STJ, DJ: 12.09.2004

${ }^{27}$ STJ, EDcl no MS 18.694/DF, rel. Min. Benedito Gonçalves, Primeira Seção, DJ: 12/06/2013 
9.784/99, permite sua anulação a qualquer tempo caso fique demonstrada, no âmbito de procedimento administrativo, a má-fé do beneficiário [...].

O AgRg no Agravo em REsp n ${ }^{0} 3.214-D^{28}$ em que se discutia a incidência da decadência para a Administração anular ato de nomeação de servidor, com o acúmulo ilegal de cargos públicos, restou assentado que a má-fé do servidor - caracterizada pela não efetivação da escolha que já havia feito formalmente em mais de uma oportunidade deveria afastar a incidência do prazo decadencial do art. 54, da Lei 8.974/99.

No mesmo sentido a jurisprudência da Suprema Corte, que no julgamento do RMS $31027 \mathrm{ED} / \mathrm{DF}^{29}$ assim se manifestou:

[...] Também não há que se falar em violação do art. 54 da Lei 9.784/99. A decadência pode ser afastada caso configurada a má-fé do interessado, $\mathrm{o}$ que deve ser analisado em procedimento próprio, com o respeito às garantias da ampla defesa e do devido processo legal [...]

Luciano Ferraz ${ }^{30}$, admitindo ser controvertida a posição assumida, sustenta que a despeito da exceção prevista na parte final do art. 54 - quanto à não incidência de prazo decadencial para anulação de atos, cujos destinatários estejam de má-fé -,

haver hipóteses em que o passar dos anos - vários anos - sepultará, mercê da incidência direta do princípio da segurança jurídica, a possibilidade em si de comprovar-se a má-fé do destinatário do ato (para evitar a decadência) e mesmo do agente que o praticou (para responsabilizá-lo), cristalizando em definitivo os vícios eventualmente existentes.

\footnotetext{
${ }^{28}$ STJ , EDcl nos EDcl no AgRg no Ag em REsp n ${ }^{\circ} 3.214-D F$, rel. Min. Humberto Martins, Segunda Turma, DJ: $13 / 12 / 2011$

${ }^{29}$ STJ, EDcl no RMS 31027 ED / DF, rel. Min. Dias Toffoli, Primeira Turma, DJ: 26/06/2012

${ }^{30}$ FERRAZ, Luciano. "Segurança jurídica positivada: interpretação, decadência e prescritibilidade". Revista Eletrônica sobre a Reforma do Estado (RERE), Salvador, Instituto Brasileiro de Direito Público, n. 22, junho, julho, agosto, 2010. Disponível na Internet: [http://www.direitodoestado.com/revista/RERE-22-JUNHO2010-LUCIANO-FERRAZ.pdf] . Acesso em: 15/03/2013, p.15
} 
E, quanto a esta pretensão de comprovar a má-fé do destinatário do ato, por não haver prazo mais elástico em regras de direito público, o autor entende incidir o prazo prescricional de dez anos do art. 205 do Código Civil.

Em que pese a autoridade dos autores mencionados que entendem incidir prazo decadencial para anulação de atos ampliativos direitos, cujos beneficiários tenham agido com má-fé, estamos entre os que interpretam a ressalva contida no art. 54, da Lei 9.784/99 no sentido da imprescritibilidade.

Desta forma, concluímos que a má-fé do beneficiário do ato inválido é fundamento da exceção à regra de incidência de prazo decadencial para anulação de ato administrativo.

Não existindo regra específica, como a do art. 54, da Lei 9.784/93, o afastamento da incidência de prazo decadencial para anulação dos atos ampliativos de direitos, cujo beneficiário esteja de má-fé, justifica-se pelo princípio da moralidade. Neste caso, é este o princípio que deverá prevalecer ante sua ponderação com o princípio da segurança jurídica.

\subsection{Prescrição da pretensão de pleitear judicialmente a anulação do ato} administrativo inválido

O ato administrativo inválido pode ser invalidado tanto pela Administração Pública, independentemente de provocação, em razão do exercício da autotutela, como pelo Poder Judiciário, mediante provocação.

Podem pleitear a anulação judicial do ato administrativo, o particular, o Ministério Público ou a Administração Pública. No entanto, para a Administração, o pleito judicial é desnecessário enquanto não esgotado seu prazo decadencial para exercício da autotutela.

As ações previstas pelo ordenamento jurídico para tal fim são: ação popular, ação civil pública, mandado de segurança individual e coletivo e ação ordinária.

A ação popular, que pode ser proposta por qualquer cidadão ${ }^{31}$, objetiva anulação do ato ilegal lesivo ao patrimônio público e a condenação de pagamento em

\footnotetext{
${ }^{31}$ Cidadão é o eleitor, nos termos do que dispõe o $\S 3^{\circ}$, do art. $1^{\circ}$, da Lei $4.717 / 65$
} 
perdas e danos, a fim de se recompor o patrimônio lesado. O prazo prescricional para propositura desta ação é de cinco anos, contados da data da prática do ato ilegal.

A ação civil pública tem como legitimados para sua propositura, o Ministério Público, a Defensoria Pública, as entidades da Administração Direta e Indireta de todos os níveis da federação e as associações constituída há pelo menos 1 (um) ano nos termos da lei civil e que incluam, entre suas finalidades institucionais, a proteção ao meio ambiente, ao consumidor, à ordem econômica, à livre concorrência ou ao patrimônio artístico, estético, histórico, turístico e paisagístico (art. $5^{\circ}$, da Lei 7.347/85). Pode ter como objeto obrigação de fazer ou não fazer, a anulação de ato ilegal lesivo a interesses difusos e coletivos e o ressarcimento do dano.

Embora a Lei 7.347/85, que regulamenta o procedimento da ação civil pública, não estabeleça prazo prescricional para sua propositura, o Superior Tribunal de Justiça tem reconhecido ser o mesmo da ação popular, ou seja, cinco anos, contados da data do ato lesivo ${ }^{32}$.

O Mandado de Segurança individual, e o coletivo, são instrumentos através dos quais se pleiteia anulação de ato lesivo a direito individual ou de um grupo de pessoas. O prazo, que é decadencial, é de 120 dias contados da data da prática do ato.

O particular ainda poderá pleitear a anulação de ato lesivo por meio de ação ordinária anulatória, que neste caso, por força do que dispõe $o$ art. $1^{\circ}$ do Decreto 20.910/32, tem prazo prescricional de cinco anos.

Percebe-se que, à exceção do Mandado de Segurança, aplica-se ao controle jurisdicional dos atos administrativos o prazo prescricional de cinco anos.

Este prazo é o mesmo tanto para a pretensão do particular pleitear anulação jurisdicional de ato administrativo, como para a Administração requerer anulação de ato administrativo ampliativo da esfera de direitos do particular.

Surge, nesse passo, a seguinte questão: O ajuizamento de ação, pela Administração Pública, para invalidar ato administrativo, somente pode ocorrer após o exaurimento do prazo decadencial?

\footnotetext{
${ }^{32}$ Disso é exemplo, os acórdãos proferidos nos Resp 727131-SP, rel Min. Luiz Fux, Primeira Turma, DJ 23/04/2008; AgRg nos EAREsp 92926-PR, rel. Min. Ari Pargendler, Corte Especial, DJ: 17/04/2013; AgRg no AREsp 113967 / PR, rel. Min. Sidnei Benedeti, Terceira Turma, DJ: 19/06/2012.
} 
Em outras palavras, a decadência do exercício à autotutela é condição necessária ao ajuizamento de ação judicial para invalidar ato administrativo?

Entendemos que sim, porquanto a Administração, tendo o poder de autotutela, preferindo recorrer, desde logo, à ação judicial, dada sua desnecessidade, estará desrespeitando o princípio da eficiência administrativa.

O estabelecimento de prazo decadencial para o exercício da autotutela é matéria de Direito Administrativo. Em nosso sistema jurídico, cada unidade da Federação tem competência para estabelecer seus prazos decadenciais em matéria de Direito Administrativo. Quando esse prazo, estabelecido pela unidade da Federação, for menor que o previsto para o controle jurisdicional - 5 anos -, somente com o esgotamento do prazo decadencial previsto é que a Administração poderá pleitear judicialmente a anulação de ato administrativo.

João Francisco da Motta $^{33}$ salienta que os prazos decadencial (controle interno) e prescricional (controle externo) aplicam-se sucessivamente mesmo quando ambos forem quinquenais. Segundo ele, "a concomitância destes prazos, ambos quinquenais, inviabilizaria na prática o controle externo, ao arrepio do disposto no art. $5^{\circ}$, inciso XXXV, da Constituição Federal”.

Ora, percebe-se que o art. $5^{\circ}$, inciso XXXV, da Constituição Federal, objetiva garantir a apreciação judicial de uma pretensão de quem não tem o poder de autotutela. Assim, somente o particular que não dispõe deste poder é que precisa pleitear administrativa ou judicialmente a anulação de ato administrativo.

Admitindo-se o entendimento do autor, estar-se-ia afrontando expressas disposições legais: a) art. 21, Lei 4.717/65 (prazo prescricional de 5 anos da ação popular), b) art. $1^{\circ}$ do Decreto $20.910 / 32$ (prazo prescricional para todas as ações contra o Poder Público). Também se estaria contrariando o principio da isonomia. Estar-se-ia criando uma situação de desigualdade - não prevista no ordenamento jurídico - entre a Administração Pública e o particular. Assim, qual seria a justificativa para que a Administração tenha prazo prescricional mais dilatado para pleitear anulação de ato administrativo? O particular teria o prazo de 5 anos para ver desconstituída uma situação que causou lesão a seu direito, enquanto a Administração teria o dobro do prazo para pleitear anulação de ato ampliativo da esfera de direitos do particular.

${ }^{33}$ MOTTA, João Francisco da. Invalidação dos atos administrativos. cit., p. 181 
É certo que a Administração Pública assume posição privilegiada quando atua em juízo, mas tal posição, fundamentada no princípio da supremacia do interesse publico sobre o privado, decorre de disposição legal expressa ${ }^{34}$, não se podendo cogitar em conferir outros "privilégios” processuais sem previsão legal.

\subsubsection{Exceção à regra de prescrição para pleitear anulação}

Grande parte da doutrina e a jurisprudência consideram imprescritíveis as ações de ressarcimento ao Erário, por força do que dispõe o art. $37, \S 5^{\circ}$, da Constituição Federal.

No MS 26.210-DF reconheceu-se, por maioria de votos, a imprescritibilidade da ação de ressarcimento, promovida pelo Tribunal de Contas da União, que visava obter a devolução do valor pago a título de bolsa à impetrante, em razão desta ter descumprido cláusula contratual que determinava seu retorno ao País após o término do curso no exterior.

No mesmo sentido, os seguintes julgados:

AGRAVO REGIMENTAL NO AGRAVO DE INSTRUMENTO. AÇÃO CIVIL PÚBLICA. CONCESSIONÁRIA DE SERVIÇO PÚBLICO. CONTRATO. SERVIÇOS DE MÃO-DE-OBRA SEM LICITAÇÃO. RESSARCIMENTO DE DANOS AO ERÁRIO. ART. 37, § 5 , DA CF. PRESCRIÇÃO. INOCORRÊNCIA.

1. As ações que visam ao ressarcimento do erário são imprescritíveis (artigo 37, parágrafo $5^{\circ}$, in fine, da CF). Precedentes.

2. Agravo regimental a que se nega provimento ${ }^{35}$.

AGRAVO REGIMENTAL NO AGRAVO DE INSTRUMENTO. DIREITO CONSTITUCIONAL E DIREITO PROCESSUAL CIVIL. AÇÃO DE RESSARCIMENTO DE DANO AO ERÁRIO. ART. 37, §

\footnotetext{
${ }^{34}$ Pode-se citar, a título de exemplo, a previsão na Lei 6830/80 de procedimento próprio para execução de seus créditos fiscais, prazo em dobro para recorrer e em quadruplo para contestar (art. 188, Código de Processo Civil), pagamento de custas à final, se vencida (art. 27, Código de Processo Civil), processo especial de execução (art. 100, da Constituição Federal)

${ }^{35}$ STJ, AI 712.435-AgR, Rel. Min. Rosa Weber, Primeira Turma, DJe 12.4.2012
} 
5', DA CONSTITUIÇÃO FEDERAL. IMPRESCRITIBILIDADE. REPERCUSSÃO GERAL PRESUMIDA. AGRAVO REGIMENTAL DESPROVIDO. 1. A repercussão geral é presumida quando o recurso versar questão cuja repercussão já houver sido reconhecida pelo Tribunal ou quando impugnar decisão contrária a súmula ou a jurisprudência dominante desta Corte (artigo 323, $\S 1^{\circ}$, do RISTF ). 2. O Pleno do Supremo Tribunal Federal, no julgamento do MS 26.210, Relator o Ministro Ricardo Lewandowski, DJ de 10.10.08, fixou entendimento no sentido da imprescritibilidade da ação de ressarcimento de dano ao erário. 3. In casu, o acórdão originariamente recorrido assentou: "AGRAVO. DECISÃO PROFERIDA EM AGRAVO DE INSTRUMENTO. ART. 557, CAPUT, DO CÓDIGO DE PROCESSO CIVIL. AÇÃO CIVIL PÚBLICA. PRETENSÃO RESSARCITÓRIA. IMPRESCRITIBILIDADE. 1. Matéria possível de ser julgada por meio de decisão monocrática, na forma do art. 557 do Código de Processo Civil, haja vista a manifesta improcedência da pretensão recursal. 2. A pretensão ressarcitória é imprescritível, nos termos do que dispõe o art. 37 , §5 $5^{\circ}$, da constituição federal. Precedentes dos tribunais. RECURSO DESPROVIDO.' 4. Agravo regimental desprovido ${ }^{36}$.

Agravo regimental em recurso extraordinário. 2. Ação de ressarcimento de danos ao erário. Art. $37, \S 5^{\circ}$, da Constituição Federal. Imprescritibilidade. Precedentes. 3. Agravo regimental a que se nega provimento $^{37}$.

Em que pese prevalecer na jurisprudência o entendimento de que a ação de ressarcimento é imprescritível, Luciano Ferraz ${ }^{38}$ discorda afirmando que

essa interpretação para além de ultrapassar própria letra constitucional (que textualmente não diz que ditas ações são imprescritíveis) termina por fulminar qualquer possibilidade de prescrição de ações que tenham

${ }^{36}$ STJ, AI 848.482-AgR, Rel. Min. Luiz Fux, Primeira Turma, DJe 22.2.2013

${ }^{37}$ STF, RE 646.741-AgR, Rel. Min. Gilmar Mendes, Segunda Turma, DJe 22.10.2012

${ }^{38}$ FERRAZ, Luciano. Op. cit., p.17-18 
como pedido o ressarcimento em favor da fazenda pública.(...) Dentro dessa lógica interpretativa, por exemplo, estariam aniquilados os prazos prescricionais da ação popular (art.23 da Lei 4.717/65), da ação civil pública (que o STJ, por analogia, tem reconhecido ser o mesmo da ação popular), nas ações regressivas contra servidores públicos (art. 37, §6 parte final, da Constituição e 142 da Lei 8.120/90: embora aqui o prazo seja decadencial), nas ações de execução fiscal (art. 173 e 174).

O autor propõe uma interpretação do art. $37, \S 5^{\circ}$, da Constituição Federal, de forma a conciliá-lo com o principio da segurança jurídica, prestigiando a prescritibilidade das ações típicas e das ações de ressarcimento, mas concedendo prazo mais dilatado para as mesmas.

Bate-se ele por uma leitura conjugada dos $\S \S 4^{\circ}$ e $5^{\circ}$ do art. 37 , da Constituição Federal. Desta forma, conclui-se que os ilícitos de que cogita o $\S 5^{\circ}$ são de atos de improbidade administrativa. Então, a ressalva, na parte final do $\S 5^{\circ}$, significa que durante o transcurso do prazo de prescrição das sanções de improbidade, não flui o prazo de prescrição do respectivo ressarcimento.

Um dos fundamentos apresentados para refutar a tese da imprescritibilidade baseia-se na afirmação de Sergio de Andréia Ferreira ${ }^{39}$ de que a última versão do Projeto de Constituição consagrava a locução "ressalvadas as respectivas ações de ressarcimento, que serão imprescritíveis", tendo sido a mesma alterada e transposta para o $\S 5^{\circ}$ da Carta Magna sem as três ultimas palavras (que serão imprescritíveis). Desta forma, se a intenção do Constituinte fosse determinar a imprescritibilidade das ações de ressarcimento, não haveria motivo justificador da remoção desta expressão, porquanto a Constituição, quando quis determinar a imprescritibilidade, o fez expressa e textualmente, como por exemplo, nos art. $5^{\circ}$, XLII: “a prática do racismo constitui crime inafiançável e imprescritível...”, $5^{\circ}$, XLIV: “constitui crime inafiançável e imprescritível a ação de grupos armados...”, 183, §3 e 191, parágrafo único: “os imóveis públicos não serão adquiridos por usucapião”.

\footnotetext{
${ }^{39}$ FERREIRA, Sérgio de Andréia. Comentários à Constituição. Rio de Janeiro: Fritas Bastos, 1991, Vol 3., p. 313, apud SILVA, Almiro do Couto e. "O princípio da segurança jurídica (proteção à confiança) no direito público brasileiro e o direito da Administração Pública de anular seus próprios atos administrativos: o prazo decadencial do art. 54 da Lei do Processo Administrativo da União (Lei 9.784/99)". Revista Eletrônica de Direito do Estado, Salvador, Instituto de Direito Público da Bahia, n. 2, abril/maio/junho, 2005. Disponível na Internet: [http://www.direitodoestado.com.br]. Acesso em 12 de março de 2013, p. 45, nota 78
} 
O voto vencido do ministro Marco Aurélio, proferido no MS 26.210, assentou não ser possível

colocar na mesma vala a situação patrimonial alusiva ao ressarcimento e outras situações em que a Constituição afasta a prescrição. O constituinte de 1988 foi explícito, em certos casos, quanto a ausência de prescrição. Aqui não. Não posso conceber que simplesmente haja o constituinte de 1988 deixado sobre a cabeça de possíveis devedores do erário, inclusive quanto ao ressarcimento por ato ilícito, praticado à margem da ordem jurídica, uma ação exercitável a qualquer tempo.

Como quer que seja, parece-nos que a redação do dispositivo constitucional não deixa margem a dúvidas. Com efeito, depois de dizer que "A lei estabelecerá os prazos de prescrição para ilícitos praticados por qualquer agente, servidor ou não, que causem prejuízos ao erário", ressalva, expressamente, "as respectivas ações de ressarcimento".

Em outras palavras, determina, como regra, que a lei estabeleça prazos de prescrição para ilícitos que causem prejuízos ao Erário. Porém, ao estabelecer a ressalva relativa às ações respectivas de ressarcimento, está o legislador deixando claro que para essas ações a lei não estabelecerá prazos de prescrição, mesmo que se cuidem de ilícitos que tragam prejuízos ao Erário.

Sem qualquer relevo, para a interpretação, o fato de haver, na redação originária do texto, a expressão "que serão imprescritíveis", que foi posteriormente excluída da redação final do dispositivo constitucional. A exclusão certamente ocorreu para evitar redundância. De fato, ao ressalvar expressamente as respectivas ações de ressarcimento, o legislador quis dizer que a regra geral, constante da primeira parte do dispositivo, não se aplicava às ações de ressarcimento. Dai porque a manutenção da expressão "que serão imprescritíveis” implicaria em redundância.

Além do mais, é notória a deficiência redacional de nosso legislador.

Outra exceção à regra de prescrição, diz respeito a vício que afronte dispositivo constitucional. Isso ocorre quando o ato é editado com base em lei inconstitucional ou quando apresente, ele próprio, dissonante com os princípios e normas constitucionais. 
No entanto, verifica-se haver graus distintos de rejeição ao ato administrativo inconstitucional, dependendo de se tratar de ato baseado em lei que posteriormente é declarada inconstitucional ou quando é o próprio ato que fere dispositivo ou princípio constitucional.

Verifiquem-se as hipóteses em que há afronta do ato às normas que impõem a obrigatoriedade de concurso público, que proíbem o acúmulo remunerado de cargos públicos, e a que obriga a Administração a realizar procedimento licitatório. Nestes casos, o Supremo Tribunal Federal tem reconhecido a imprescritibilidade, possibilitando a desconstituição do ato inválido independentemente do tempo decorrido.

No RE 381.204, em que se discutia a legitimidade de percepção simultânea de três aposentadorias por servidor público - por mais de vinte anos - a relatora Ministra Ellen Gracie afirmou “que o direito adquirido e o decurso de longo tempo desde o início dos pagamentos indevidos não podem ser invocados quando se tratar de manifesta contrariedade à Constituição, como a observada nos autos", e concluiu pelo acerto da supressão de um destes benefícios ${ }^{40}$.

Da mesma forma, no MS 28273 AgR/DF restou assentado que "situações flagrantemente inconstitucionais como o provimento de serventia extrajudicial sem a devida submissão a concurso público não podem e não devem ser superadas pela simples incidência do que dispõe o art. 54 da Lei 9.784/99, sob pena de subversão das determinações incertas na Constituição Federal." ${ }^{41}$

A jurisprudência do Superior Tribunal de Justiça alinha-se ao entendimento do Supremo. Vejamos os seguintes precedentes:

ADMINISTRATIVO. PROCESSUAL CIVIL. RECURSO ESPECIAL. SERVIDOR PÚBLICO DO PODER EXECUTIVO ESTADUAL. TRANSFERÊNCIA PARA O QUADRO DE PESSOAL DO PODER LEGISLATIVO. AÇÃO CIVIL PÚBLICA PROPOSTA PELO PARQUET ESTADUAL OBJETIVANDO A ANULAÇÃO DESSE ATO. PRESCRIÇÃO. NÃO OCORRÊNCIA. RETORNO DOS AUTOS À INSTÂNCIA DE ORIGEM PARA PROSSEGUIMENTO DO FEITO. RECURSO CONHECIDO E PROVIDO.

\footnotetext{
${ }^{40}$ STJ, RE 381.204-1/RS, rel. Min. Ellen Gracie, 2a. Turma, DJ: 11.11.2005.
}

${ }^{41}$ STJ, AgR em MS 28273-DF, rel. Min. Ricardo Lewandowiski, DJ: 13.12 .2012 
[...] 3. Com efeito, nos termos da Súmula 685/STF, "É inconstitucional toda modalidade de provimento que propicie ao servidor investir-se, sem prévia aprovação em concurso público destinado ao seu provimento, em cargo que não integra a carreira na qual anteriormente investido".

4. Por sua vez, situações flagrantemente inconstitucionais como o provimento de cargo público efetivo sem a devida submissão a concurso público não podem e não devem ser superadas pelo eventual reconhecimento da prescrição ou decadência, sob pena de subversão das determinações insertas na Constituição Federal. Precedente: MS 28.279/DF, Rel. Min. ELLEN GRACIE, Tribunal Pleno, DJe 28/4/10. $[\ldots]^{42}$

No AgR 91.443-GO, reconheceu-se a imprescritibilidade da anulação de ato que outorgou concessão de serviço público, sem prévia licitação.

PROCESSUAL CIVIL E ADMINISTRATIVO. AGRAVO INTERNO. ATOS ADMINISTRATIVOS NULOS. DECRETAÇÃO DE NULIDADE EM FACE DA CF/88. AUSÊNCIA DE PRESCRIÇÃO.

[...] 2. A jurisprudência do STJ já reconheceu a imprescritibilidade das ações que visam a declaração de nulidade de ato por falta de licitação, razão pela qual deve subsistir o acórdão impugnado ao afastar a prescrição da pretensão do Ministério Público, autor da ação e ora agravado. Precedentes.[...]

Já nas hipóteses em que o vício decorre de ato baseado em lei inconstitucional, percebe-se certa tolerância, com o reconhecimento de prescrição, impossibilitando seu desfazimento, em atenção ao princípio da segurança jurídica e boa-fé dos administrados.

Nesse sentido se pronunciou o Min. Gilmar Mendes, ao proferir voto no RE AgR $217.141^{43}$ :

${ }^{42}$ REsp1293379-RN, Rel. Min. Arnaldo Esteves Lima, Primeira Turma, DJ: 26/02/2013

${ }^{43}$ RE AgR 217.141, Rel. Min. Gilmar Mendes Segunda Turma, DJ: 13/06/2006 
Além disso, acentue-se, desde logo, que, no direito brasileiro, jamais se aceitou a ideia de que a nulidade da lei importaria na eventual nulidade de todos os atos que com base nela viessem a ser praticados. Embora a ordem jurídica brasileira não disponha de preceitos semelhantes aos constantes do $\S 79$ da Lei do Bundesverfassungsgericht, que prescreve a intangibilidade dos atos não mais suscetíveis de impugnação, não se deve supor que a declaração de nulidade afete, entre nós, todos os atos praticados com fundamento na lei inconstitucional. É verdade que o nosso ordenamento não contém regra expressa sobe o assunto, aceitandose, genericamente, a ideia de que o ato fundado em lei inconstitucional está eivado, igualmente, de iliceidade (Cf., a propósito, RMS 17.976, Rel. Amaral Santos, RTJ 55, p. 744). Concede-se, porém, proteção ao ato singular, em homenagem ao princípio da segurança jurídica, procedendose à diferenciação entre o efeito da decisão no plano normativo (Normebene) e no plano do ato singular (Einzelaktebene) mediante a utilização das chamadas fórmulas de preclusão (cf. Ipsen, Jorn, Rechtsfolgen der Verfassungswidrigkeit von Norm und Einzelakt, BadenBaden, 1980, p. 266 e se. Ver, também, Mendes, Gilmar, Jurisdição Constitucional, $5^{\text {a }}$. ed., São Paulo: Saraiva, 2005, p. 334).

Outra hipótese de reconhecimento, pela jurisprudência, da imprescritibilidade, se relaciona com violação ao princípio da moralidade administrativa. Isso porque "a permanência dos mesmos no sistema em nada contribui para a paz social, na medida em que objeto de justa indignação dos administrados e motivo de descrédito das instituições" ${ }^{\prime 4}$.

A título de exemplo, podemos citar as exonerações sumárias de servidores do Judiciário e Ministério Público, nos casos em que configurado nepotismo. Tais exonerações, quando submetidas à apreciação da Suprema Corte, foram consideradas corretas e necessárias à concreta realização do princípio da moralidade administrativa ${ }^{45}$.

\footnotetext{
${ }^{44}$ MOTTA, João Francisco da. Invalidação dos atos administrativos. cit., p. 169

${ }^{45}$ Idem, ibidem, p. 169
} 


\subsection{A prescrição e decadência do poder de anular os atos} administrativos ilegais como forma de restauração da legalidade.

Ao falarmos em prescrição ou decadência do poder de revisão (anulação) do ato administrativo ilegal, surge a questão: A prescrição ou decadência restaura a legalidade?

A resposta pode ser positiva ou negativa, dependendo do enfoque que se dê aos conceitos envolvidos.

Se considerarmos a legalidade em sentido estrito, ou seja, para que o ato administrativo seja considerado legal deve estar em perfeita consonância com a lei, a resposta é negativa. O decurso do tempo, por si só, não transformará o ato que desatendeu determinações legais. Isso só será efetivamente possível com a produção de novo ato, idêntico ao anterior, sem vício, e que acolha como seus os efeitos do ato inválido, mediante convalidação. Assim, a restauração da legalidade em sentido estrito somente será possível mediante convalidação.

O decurso do prazo prescricional ou decadencial, neste caso, apenas permite que se "tolere" uma situação ilegal evitando a instabilidade que seria gerada pela anulação do ato depois do decurso de um longo lapso temporal.

Michel Stassinopoulos ${ }^{46}$ afirma que o Conselho de Estado Francês entende que o ato que se tornou irretratável pelo decurso do tempo é apenas tolerado pelo ordenamento jurídico por determinação legal, mas não é considerado legal. Eis o exemplo que apresenta: funcionário é transferido de um posto na província para um posto na administração central, sem que preenchesse todos os requisitos legais para tal transferência. Considerando que o funcionário estava de boa-fé, não tendo concorrido com a ilegalidade, depois de certo tempo, o ato se tornou irretratável pela Administração Pública, não podendo mais ser anulado. Posteriormente, esse mesmo funcionário requer sua promoção, o que é indeferido pela Administração Pública. Recorre, então, ao Conselho de Estado, que confirma o indeferimento da Administração sob o fundamento de que "o ato ilegal de transferência para o posto central, tornou-se irretratável, mas não pode servir de base ao ato de promoção que pressupõe uma nomeação legal".

\footnotetext{
${ }^{46}$ STASSINOPOULOS, Michel. Traité des actes adminitratifs. Paris: Librairie Générale de Droit et de Jurisprudence, 1973, p. 276
} 
Portanto, o ato, embora irretratável, é tolerado, mas permanece ilegal, em razão do que não se pode afirmar que a prescrição ou a decadência restauram a legalidade.

Em sentido contrário, Antônio Carlos Cintra do Amaral $^{47}$, entende ser a prescrição forma de convalidação e, portanto, de restauração da legalidade, quando o prazo prescricional encontra-se expressamente previsto em lei. O autor afirma: "Não quer isto dizer, porém, que o ato administrativo não possa ser convalidado pelo decurso de prazo prescricional previsto em lei, tal como ocorre no direito brasileiro".

Mas, considerando-se a legalidade em sentido amplo, é possível considerar a incidência da prescrição ou decadência como forma de restaurar a legalidade.

A partir do momento que uma lei impede que determinado ato (ilegal) possa ser revisto (ou anulado) está sendo atendido o princípio da legalidade. Se até então aquela circunstancia era ilegal, a partir da incidência da prescrição, a não anulação do ato passa a atender outra determinação legal que se sobrepõe à anterior.

Poder-se-ia argumentar com a existência de casos em que não há lei determinando o prazo prescricional ou decadencial. Mas, nestes casos, a irretratabilidade do ato administrativo ilegal encontra fundamento no princípio constitucional da segurança jurídica e do interesse público, igualmente abrangidos pela legalidade em sentido amplo.

Pode-se concluir, então, que considerando a legalidade em sentido amplo, a prescrição ou decadência recompõe a legalidade promovendo-lhe um rearranjo.

${ }^{47}$ AMARAL, Antonio Carlos Cintra do. Extinção do Ato Administrativo. São Paulo: Revista dos Tribunais, 1978, p. 65 


\section{O DEVIDO PROCESSO LEGAL NA REVISÃo DOS ATOS ADMINISTRATIVOS INVÁLIDOS}

Como visto anteriormente, constitui indiscutível dever da Administração Pública a restauração da legalidade, o que pode ser feito por meio de anulação, da revogação ou da convalidação. Por força de seu poder de autotutela, consubstanciado na súmula n. 473 da Suprem Corte, "a Administração pode anular seus próprios atos, quando eivados de vícios que os tornam ilegais, porque deles não se originam direitos; ou revogálos, por motivo de conveniência e oportunidade, respeitados os direitos adquiridos, e ressalvada em todos os casos a apreciação judicial”.

Nesse sentido, a Lei 9.784/1999 conferiu especial relevo à autotutela administrativa, dispondo em seu art. 53: “A Administração deve anular seus próprios atos quando eivados de vício de legalidade, e pode revogá-los por motivo de conveniência ou oportunidade, respeitados os direitos adquiridos". E, ainda, em seu art. 55 conferiu à Administração a possibilidade de convalidar os atos, cuja ilegalidade não acarrete lesão ao interesse público, nem prejuízo a terceiros.

Esses dispositivos legais, como se percebe, ao mesmo tempo em que conferem uma prerrogativa à Administração (poder de autotutela), limitam sua atuação em face dos direitos de terceiros que podem ser prejudicados.

Assim, ao constatar a ocorrência de uma ilegalidade, não deve a Administração proceder, de imediato, à revisão (anulação, revogação, convalidação) do ato, porque em tese tal providencia poderá lesar esfera jurídica de terceiros.

A fim de garantir uma decisão justa e de acordo com o interesse público, faz-se necessária a adoção de um procedimento administrativo, prévio ao ato administrativo final (anulação, revogação, convalidação), por meio do qual se assegure aos eventuais lesados o direito ao contraditório e à ampla defesa, nos termos do que dispõe o art. $5^{\circ}$, LV, da Constituição Federal: "aos litigantes em processo judicial ou administrativo serão assegurados o contraditório e a ampla defesa com todos os recursos a ela inerentes". 
Sundfeld ${ }^{1}$ ao discorrer sobre a importância do procedimento administrativo para permitir que o administrado participe na formação do ato final afirma que

\footnotetext{
o processo é a contrapartida que se assegura à liberdade pelo fato de o ato da autoridade ser unilateral, dentro da proposta de resguardar o equilíbrio entre a liberdade e autoridade. Sem que o ato estatal deixe de ser ato de autoridade e, portanto, imperativo, se permite o exercício da liberdade: condicionando a produção do ato a um processo regulado do qual o indivíduo possa participar.
}

O processo administrativo permite, então, um controle mais amplo da atividade administrativa, na medida em que favorece o controle do processo de formação das decisões, não se limitando a um controle a posteriori. Daí a importância de se assegurar que a decisão que culmine na revisão de ato administrativo inválido passível de restringir direito ou interesses de terceiros seja precedida de procedimento administrativo.

Desta forma, abordaremos de forma geral alguns aspectos do processo administrativo, para em seguida verificarmos de forma específica o processo administrativo de revisão de atos administrativos inválidos.

\subsection{Questões terminológicas: processo ou procedimento} administrativo

O termo processo sempre esteve associado a função jurisdicional. Por esta razão, tanto a doutrina processualista como a administrativista tinham a ideia de processo como exclusividade da função jurisdicional. Com isso, buscava-se evitar confusão entre a forma de atuar do Poder Judiciário e a forma de atuar da Administração Pública. E o termo procedimento era reservado para o âmbito administrativo ${ }^{2}$.

\footnotetext{
${ }^{1}$ SUNDFELD, Carlos Ari. "A importância do procedimento administrativo". Revista de Direito Público. São Paulo, vol. 84, p. 65-74, out. dez. 1987, p.67

${ }^{2}$ MEDAUAR, Odete. A processualidade no Direito Administrativo. $2^{\mathrm{a}}$ ed., São Paulo: Revista dos Tribunais, 2008, p. 18
} 
No entanto, com a evolução nas concepções de processualistas e administrativistas passou-se a aceitar uma processualidade ligada aos três poderes do Estado - a processualidade ampla - e consequentemente a processualidade administrativa.

Com a aceitação da processualidade administrativa surgiu a questão: a processualidade se desenvolve pelo processo ou pelo procedimento? Para responde-la é preciso diferenciar os dois institutos.

Ao longo dos anos, na medida em que se desenvolvia na doutrina nacional e estrangeira, a ideia da processualidade administrativa, vários critérios foram utilizados na tentativa de diferenciar as duas figuras.

Dentre estes critérios, podemos citar o desenvolvido por Benvenutti ${ }^{3}$, segundo o qual procedimento é gênero, e processo é espécie. Para ele, procedimento é o modo de exteriorização da função, ou seja, é a história da transformação do poder em ato. Considerando que esta concretização nem sempre é instantânea, a função consistiria neste espaço entre o Poder e o ato. Desta forma, o modo de fazer-se do ato, ou o caminho que se percorre entre o Poder e o ato é o procedimento. Este procedimento, quando visto sob o aspecto subjetivo diferencia-se em procedimento em sentido estrito e processo. $\mathrm{O}$ procedimento em sentido estrito tem como característica a sucessão de atos realizados pelo mesmo sujeito a quem compete editar o ato final e que é o único interessado. Ao contrário, o processo caracteriza-se pela atuação de sujeitos diversos daquele a quem compete editar $\mathrm{o}$ ato e também com interesses diversos. E, o ato final atende interesse dos destinatários e não do sujeito autor do ato.

Fazzalari ${ }^{4}$ prestou importante contribuição ao estudo da processualidade administrativa, tendo acrescentado à teoria esboçada por Benvenutti o critério do contraditório para diferenciação entre processo e procedimento. Para ele, o procedimento em que há contraditório é designado processo. Esta teoria é amplamente aceita na atualidade.

Esse critério (contraditório) é o adotado por Odete Medauar ${ }^{5}$, com quem concordamos. Na linha de pensamento da autora, procedimento administrativo é gênero,

\footnotetext{
${ }^{3}$ BENVENUTI, Feliciano. "Funzione amministrativa, procedimento, processo". Rivista Trimestrale di Diritto Púbblico. Milano: Giufrée, Ano II, 1952, p. 118-145

${ }^{4}$ FAZZALARI, Elio. Processo (teoria generale). Novissimo digesto italiano, v. 13, 1966, p. 1067-1076, p. 1072 apud MEDAUAR, Odete. A processualidade no Direito Administrativo. $2^{\mathrm{a}}$ ed. São Paulo: Revista dos Tribunais, 2008, p. 43

${ }^{5}$ MEDAUAR, Odete. Op. cit., p. 43
} 
do qual processo é espécie. O procedimento é a sucessão ordenada de atos que culminam num ato final. Caso haja previsão de cooperação de sujeitos, sob o prisma do contraditório, estaremos diante do processo.

É importante ressaltar que para caracterização do processo administrativo não basta a simples atuação de vários sujeitos para formação do ato final. É necessário que a participação dos interessados seja levada em consideração pelo autor do ato.

Podemos, então, concluir que a processualidade, no âmbito da Administração, se desenvolve por meio de processo administrativo.

Embora, alguns autores ainda prefiram utilizar a expressão procedimento administrativo, com o intuito de evitar confusão com o processo jurisdicional, acompanhamos o entendimento de Odete Medauar, e falamos em processo. Ainda mais porque é esta a expressão utilizada pela Carta Magna.

Portanto, a revisão dos atos administrativos inválidos que possa influir na esfera de direitos de terceiros deve ser feita mediante processo administrativo, em obediência a princípios constitucionais, dando ao particular afetado o direito de interferir na decisão final.

\subsection{Princípios informadores do processo administrativo}

A doutrina aponta, de modo geral, vários princípios informadores do processo administrativo. Alguns são gerais, porque informadores de todo o direito administrativo; outros são específicos.

Limitar-nos-emos à análise somente dos princípios informadores específicos do processo administrativo, dado o teor do trabalho.

\subsubsection{O princípio do devido processo legal}

$\mathrm{O}$ art. $5^{\circ}$, LIV, da Constituição Federal dispõe que "ninguém será privado da liberdade ou de seus bens sem o devido processo legal".

Percebe-se que, num mesmo dispositivo, o legislador constituinte estabeleceu três requisitos simultâneos a qualquer ato do poder público tendente a restringir a liberdade ou a propriedade do particular. Vale dizer, ninguém poderá ser 
privado de sua liberdade ou de seus bens, sem que haja um processo, adequadamente desenvolvido, tal como predefinido em $1 \mathrm{ei}^{6}$.

É importante lembrar que existem casos em que a Administração Pública encontra-se dispensada da instauração previa do processo administrativo, podendo executar imediatamente o ato. Tais hipóteses são justificadas pela urgência (ex: destruição de alimentos impróprios para o consumo), ou ainda, quando se tratar de atos instantâneos (ex: aplicação de multa de trânsito). Porém, mesmo nestas hipóteses assegura-se ao particular afetado pelo ato a possibilidade de requerer instauração de processo administrativo, devendo a Administração submeter-se a ele (processo) ${ }^{7}$.

Não basta a submissão da Administração a um processo. Este deve ser adequado. De acordo com Egon Bockmann Moreira $^{8}$, o adjetivo devido inserido no dispositivo constitucional em comento tem sentido de adequação da conduta administrativa. $\mathrm{O}$ autor explica que

atuação adequada, tal como exigida pela Constituição, é aquela que atende às expectativas mínimas de um Estado Democrático de Direito, devendo corresponder e satisfazer o que se espera de uma Administração aberta e participativa, em que se garante ao particular voz ativa, em condição de igualdade com o ente público e sem qualquer espécie de submissão e/ou supressão de expectações.

O adjetivo "legal" inserido no dispositivo constitucional deve ser visto sob dois aspectos. Por um lado, apresenta-se como um desdobramento do princípio da legalidade, estabelecendo a necessidade de previsão legal para toda e qualquer providência que vise restringir, direta ou indiretamente, a liberdade ou propriedade dos particulares. Isso significa que a Administração não pode, por ato administrativo, criar qualquer procedimento que autorize a imposição de obrigações ou restrições aos particulares, se não houver disposição legal prévia. Por outro lado, a qualificação "legal” diz respeito também à necessidade de o processo administrativo seguir os trâmites conforme previsão normativa. Porém, isso não significa que na ausência de disposição expressa prevendo

\footnotetext{
${ }^{6}$ MOREIRA, Egon Bockmann. Processo administrativo. Princípios Constitucionais e a Lei 9.784/1999. $4^{\mathrm{a}}$ ed. São Paulo: Malheiros, 2010, p. 292

${ }^{7}$ Idem, ibidem, p. 294

${ }^{8}$ Idem, ibidem, p. 296-297
} 
determinado tipo de processo administrativo, a Administração esteja desobrigada de instaurá-lo e a ele (processo) se submeter quando sua atuação restrinja direito dos particulares. Nesta hipótese de lacuna legislativa, aplicam-se extensiva ou analogicamente, as leis processuais em vigor?

É o que ocorre com o processo administrativo que objetive rever ato administrativo inválido. Mesmo não havendo na legislação previsão específica em relação a tal tipo de processo administrativo, o mesmo deve ser instaurado com fundamento na garantia constitucional do devido processo legal.

Percebe-se, diante do exposto que o princípio do devido processo legal é o principal fundamento justificador da obrigatoriedade da Administração instaurá-lo sempre que a revisão de ato administrativo inválido restrinja ou suprima, direta ou indiretamente, a liberdade ou propriedade dos particulares.

\subsubsection{O princípio do contraditório}

Contraditório vem de contradizer, ou seja, dizer contra. É a faculdade de reagir a uma informação, de apresentar argumentos contrários. Por isso, pressupõe a ciência prévia dos dados, fatos, argumentos ou interpretações.

Inicialmente, em razão das concepções relativas à supremacia do Estado, no sentido de que somente este era capaz de emitir juízo sobre interesse público e o administrado era visto como súdito, servil, o contraditório era exclusividade da atividade jurisdicional. No entanto, com a aceitação da processualidade ampla, aliada à busca de uma maior aproximação na relação entre Administração-administrado e, admitindo-se a existência de divergências de interesses e de interpretações jurídicas entre estes, passou a predominar o entendimento de que o contraditório não só é aceito no processo administrativo como também é pressuposto de sua validade ${ }^{10}$.

O princípio do contraditório é ínsito ao Estado Democrático de Direito, uma vez que permite a integração do particular na esfera pública. Conforme afirma Egon Bockmann Moreira ${ }^{11}$, "a democracia exige o efetivo prestígio à participação dos cidadãos na formação da vontade estatal". Por meio do contraditório o particular poderá apresentar

\footnotetext{
${ }^{9}$ Idem, ibidem, p. 299

${ }^{10}$ MEDAUAR, Odete. Op. cit., p. 103

${ }^{11}$ MOREIRA, Egon Bockmann. Op. cit., p. 311-312
} 
argumentos capazes de influir na decisão administrativa, tornando-a mais justa. Não se admite mais a ideia de que o contraditório só se faz necessário quando houver litígio. É preciso lembrar que esse princípio constitui uma forma de efetivação da democracia.

Como se disse, o contraditório é a possibilidade que tem o cidadão de apresentar argumentos para compor a vontade estatal. Para isso, é necessário que a Administração Pública considere na decisão final tudo que foi apresentado pelo administrado. Não basta permitir a participação formal do cidadão no processo administrativo e, decidir como se suas alegações não existissem.

Nesse sentido, observa Egon Bockmann Moreira $^{12}$ :

Daí o reforço da ideia de que o contraditório não configura singela exigência formal que possibilite às pessoas privadas apresentar sua defesa e cooperar na instrução probatória mas desobrigue o órgão julgador de lhes dar ciência do andamento do processo ou apreciar fundamentadamente as razões trazidas aos autos. A face substancial do princípio traz consigo o dever administrativo de serem apreciadas a contento todas as manifestações produzidas pelos interessados no processo.

A exigência de motivação é importante elemento que permite verificar se a autoridade administrativa efetivamente tomou ciência e considerou as manifestações dos administrados. É claro que o contraditório não vincula a autoridade administrativa, no sentido de obriga-la a decidir exclusivamente baseada nos argumentos apresentados pelo administrado. Mas, deve indicar quais os argumentos que influenciaram sua decisão e o porquê. É a forma de permitir a avalição de como e quanto determinado fato, documento ou alegação, influiu na a decisão final ${ }^{13}$.

Odete Medauar ${ }^{14}$ ensina que o contraditório tem como finalidades: a) tutelar as posições jurídicas dos destinatários do ato final, oferecendo a possibilidade concreta de melhor combater o ato final; b) Instruir o processo de forma que a decisão seja mais ponderada e próxima à realidade; c) Propiciar a impessoalidade, tendo em vista que igual oportunidade dada aos sujeitos entre si facilita a tomada de decisões objetivas, sem

\footnotetext{
${ }^{12}$ Idem, ibidem, p. 312

${ }^{13}$ MEDAUAR, Odete. Op. cit., p. 114

${ }^{14}$ Idem, ibidem, p. 109-110
} 
conotações pessoais e caso estas predominem, o cotejo dos dados expostos permitirá que sejam detectadas com mais nitidez; d) ampliação da transparência administrativa, em razão da participação dos interessados que permite uma visibilidade dos momentos que antecedem à decisão.

Assim, o contraditório, verificado no processo administrativo revisor de ato administrativo inválido, permite ao indivíduo apresentar argumentos, fatos e interpretações diversas daquelas da autoridade administrativa, com a possibilidade de conduzir a decisão final a seu favor. Além disso, contribui para que a decisão administrativa seja mais coerente com a realidade.

\subsubsection{O princípio da ampla defesa}

O princípio da ampla defesa é originário do processo penal, estendendose posteriormente ao processo administrativo disciplinar. É por isso que durante muito tempo a garantia da ampla defesa esteve restrita aos processos em que havia "acusado", ou seja, em que houvesse a imputação a alguém de um ato ilícito (criminal, fiscal ou administrativo) ${ }^{15}$.

A Constituição Federal de 1988 aplicou o alcance deste princípio ao dispor, no art. 5\%, LV, que "aos litigantes, em processo judicial ou administrativo, e aos acusados em geral são assegurados o contraditório e ampla defesa, com os meios e recursos a ela inerentes;".

A partir de então a ampla defesa é extensiva a todos os processos administrativos ou judiciais, seja qual for a sua natureza. Basta a existência de "litigantes", num conflito de interesses, não mais se falando em "acusados".

O texto constitucional não se limita a garantir o direito de defesa, valendo-se do adjetivo "ampla". Não basta assegurar uma defesa formal. Indispensável que esse direito seja amplo, com todos os meios inerentes à defesa.

A ampla defesa abrange o direito de ser notificado do início do processo, com a indicação objetiva dos fatos e o embasamento legal, o direito de ser cientificado, com antecedência, das medidas ou atos referentes à produção de provas, das juntadas de

${ }^{15}$ MOREIRA, Egon Bockmann. Op. cit., p. 332-333 
documentos, assim como o direito de requerer a produção de provas, vê-las realizadas e consideradas ${ }^{16}$.

Odete Medauar ${ }^{17}$ aponta algumas questões acerca da ampla defesa que têm suscitado controvérsias, quando aplicada na esfera administrativa

A primeira delas é relativa ao caráter prévio da defesa, ou seja, sua anterioridade em relação ao ato decisório. No âmbito administrativo podem ocorrer situações que envolvam risco de vida e segurança da população, cuja urgência impeça o exercício da defesa prévia. Nestas hipóteses excepcionais, a defesa é exercida posteriormente.

Outra questão refere-se à defesa técnica. A edição da súmula vinculante 5, do STF, alterou entendimento jurisprudencial anterior no sentido da obrigatoriedade de defesa técnica nos processos disciplinares de servidores, que pudessem resultar em penas graves.

No particular, Edmir Netto de Araújo $^{18}$ recomenda a harmonização da interpretação dessa Súmula Vinculante, observando:

Relativamente recente (publicada no DJU, de 16-05-2008), a Súmula Vinculante n. 5 do STF estabeleceu que "a falta de defesa técnica por advogado, no processo administrativo disciplinar, não ofende a Constituição". Não ofender a Constituição, entretanto, não significa que as leis (federal, estadual, distrital, municipal) sobre processo administrativo em geral ou disciplinar, em especial, não possam prever a obrigatoriedade de defesa técnica por advogado para indiciados, constituindo, portanto, caso de nulidade do feito, por ilegalidade, sua não observância, embora não inconstitucional, pois não ofende a Carta Magna, terá ofendido lei específica a respeito.

Relativamente aos demais processos administrativos - que não sejam disciplinares -, Odete Medauar ${ }^{19}$ entende que a defesa apresentada por advogado é obrigatória somente naqueles "cujos resultados repercutam com gravidade sobre direitos e

\footnotetext{
${ }^{16}$ MEDAUAR, Odete. Op. cit., p. 127-128

${ }^{17}$ Idem, ibidem, p. 122-126

${ }^{18}$ ARAUUJO, Edmir Netto de. Curso de Direito Administrativo. 6. ed. São Paulo: Saraiva, 2014, p. 998

${ }^{19}$ Idem, ibidem, p. 127
} 
atividades dos sujeitos, como, p. ex., interdição de atividades, fechamento de estabelecimentos, cessação do exercício profissional”.

Diante de tais considerações, entendemos que a defesa técnica é obrigatória no processo administrativo revisor de ato administrativo inválido. É que este, via de regra, pode resultar numa grave restrição a direitos, como os apontados por Odete Medauar.

É bom considerar, também, que na hipótese (revisão de ato administrativo) a questão discutida é mais jurídica que fática, pelo que a presença do advogado se torna imprescindível na defesa dos direitos do sujeito.

\subsubsection{O princípio da razoável duração do processo}

A Emenda Constitucional n. 45 inseriu no rol de garantias e direitos fundamentais (art. $5^{\circ}$, LXXVIII) o direito à razoável duração do processo judicial e administrativo. Consequentemente, no âmbito administrativo, a Administração Pública deve adotar mecanismos eficazes a fim de garantir celeridade na tramitação de seus processos administrativos.

A expressão razoável relaciona-se com as ideias de equilíbrio, de ponderação, de dosagem, de justo. Portanto, nos processos simples, repetitivos ou com orientações já consolidadas, os prazos de tramitação devem ser mais curtos que naqueles processos mais complexos.

O princípio da razoável duração do processo está relacionado com o princípio da eficiência, uma vez que este tem também em seu bojo aspectos de rapidez e celeridade nas decisões.

Há conexão, também, com o princípio da segurança jurídica, no sentido de que decisões demoradas acarretam insegurança e incerteza.

A observância deste princípio é essencial nos processos de revisão de atos administrativos inválidos, uma vez que a inércia da Administração pode ocasionar a impossibilidade de revisão de tais atos, em razão da decadência. 


\subsubsection{Princípio da oficialidade}

Este princípio determina que a Administração Pública responsabiliza-se pelo andamento do processo, independentemente da iniciativa dos particulares. Ela é responsável, inclusive, pela instrução do processo, devendo providenciar a coleta de elementos necessários ao esclarecimento de fatos pertinentes ao assunto. As principais consequências deste princípio são que a paralização ou retardamento imotivados do processo acarretam a responsabilização de seus agentes e a inércia dos sujeitos interessados não acarreta a paralisação do procedimento, salvo se se tratar de providencias solicitadas pelo particular de que dependam juntada de documentos e este não o fizer no prazo estabelecido pela Administração. Nestas hipóteses a Administração poderá encerrar o processo $^{20}$.

\subsubsection{Princípio da verdade material}

Este princípio relaciona-se com o da oficialidade, pois consagra o dever da Administração Pública de buscar todos os dados, informações, documentos, a fím de instruir o processo, não se limitando às provas requeridas e produzidas pelas partes. A Administração tem total liberdade na produção de provas, desde que obtidas por meios lícitos $^{21}$.

\subsubsection{Princípio do formalismo moderado}

Este princípio costuma ser chamado pela doutrina de princípio do informalismo. Porém, concordamos com Odete Medauar ${ }^{22}$, que prefere utilizar a expressão formalismo moderado, para evitar que se entenda que não há ritos e formas no processo administrativo. Pretende-se com essa expressão (formalismo moderado) demonstrar que a Administração deve ser flexível e adotar ritos e formas simples, de forma a propiciar um grau de certeza e segurança às suas decisões, e ao mesmo tempo facilitar a participação dos administrados. Conforme afirma a autora, este princípio "visa a impedir que minúcias e pormenores não essenciais afastem a compreensão da verdadeira finalidade da atuação"23.

\footnotetext{
${ }^{20}$ Idem, ibidem, p. 130

${ }^{21}$ Idem, ibidem, p. 131

${ }^{22}$ Idem, ibidem, p. 131

${ }^{23}$ Idem, ibidem, p. 133
} 


\title{
9.3. Finalidades do processo administrativo
}

Odete Medauar ${ }^{24}$ aponta, como finalidades do processo administrativo: a) garantir o direito dos administrados; b) propiciar um melhor conteúdo e eficácia das decisões administrativas; c) legitimar o poder; d) promover o correto desempenho da função e justiça na Administração; e) aproximar Administração e cidadãos; f) sistematizar as atuações administrativas; g) facilitar o controle da Administração; h) concretizar a aplicação dos princípios e regras comuns da atividade administrativa.

Pode-se dizer que num primeiro momento o processo administrativo cumpre uma função protetora dos direitos dos administrados, porque o ato administrativo pode afetar interesses particulares. Ao exercer essa função protetora ele propicia uma garantia prévia à edição do ato final. De se considerar, ainda, que essa proteção dada pelo processo administrativo é preferível àquela de natureza jurisdicional, porque esta ocorre $a$ posteriori.

Esse aspecto garantista do processo administrativo está intimamente ligado aos direitos fundamentais, porque incluído no rol dos direitos e garantias individuais ${ }^{25}$.

Sobre esta função garantista do processo administrativo, Egon Bockmann Moreira $^{26}$ observa:

\begin{abstract}
O processo administrativo significa meio ativo de exercício e garantia de direitos dos particulares, que têm condições de participar e controlar a sequência predefinida de atos anteriores ao provimento final. Os atos administrativos não se despem de suas principais características (presunção de legitimidade, imperatividade, exigibilidade e autoexecutoriedade), mas as pessoas privadas tomarão parte da decisão administrativa, na constante busca da concretização excelente do interesse público.
\end{abstract}

Por outro lado, com a participação dos interessados na instrução a decisão final que for produzida terá um conteúdo de melhor qualidade, havendo uma ampliação dos pressupostos objetivos da decisão administrativa ${ }^{27}$.

\footnotetext{
${ }^{24}$ Idem, ibidem, pp. 65-74

${ }^{25}$ Idem, ibidem, pp. 65-68

${ }^{26}$ MOREIRA, Egon Bockmann. Op. cit., p. 69

${ }^{27}$ MEDAUAR, Odete. Op. cit., p. 68-69
} 
A eficácia das decisões produzidas no processo administrativo também são consequência da colaboração dos interessados, com o se apresentam elas mais suscetíveis de aceitação e de cumprimento ${ }^{28}$.

Há, também, por força do processo administrativo - e esta igualmente é uma de suas funções - uma verdadeira legitimação do poder. De fato, a processualidade está associada ao exercício do poder estatal, entendido este como instrumento para que se alcance determinadas finalidades. Quando da análise dos diversos momentos de formação da decisão, é possível verificar se o poder foi exercido de acordo com as suas finalidades. Com isso alcança-se a legitimidade do ato final, que será resultado de um processo em que foram analisados diversos interesses, direitos e deveres, chegando-se a um ponto de convergência. Assim, é possível falar em nova imperatividade, designando aquela que é construída e buscada, superando a ideia de imperatividade unilateral ${ }^{29}$.

É ainda através do processo administrativo que se exerce, corretamente, a função administrativa, na medida em que permite alcançar um equilíbrio entre a autoridade do agente público e os direitos dos particulares, e um encontro de pontos de vista e interesses diversos daqueles assumido pela Administração unilateralmente ${ }^{30}$.

Possibilita o processo administrativo, ainda, uma atuação administrativa com justiça, não somente através do contraditório e da ampla defesa, como também por propiciar o sopesamento dos vários interesses que envolvem uma situação ${ }^{31}$.

Tendo em vista que o processo administrativo contempla a colaboração individual ou coletiva de sujeitos, permite uma aproximação entre Administração e cidadão, descartando-se a ideia de interesse público oposto a interesse privado ${ }^{32}$.

O processo administrativo também permite a sistematização de atuações administrativas. A organização racional da edição dos atos administrativos, simplifica práticas para a Administração e permite aos administrados o conhecimento do modo de exercício da função administrativa, possibilitando melhores condições para pleitear o reconhecimento de seus direitos ${ }^{33}$.

\footnotetext{
${ }^{28}$ Idem, ibidem, p. 69

${ }^{29}$ Idem, ibidem, p. 70

${ }^{30}$ Idem, ibidem, p.70-71

${ }^{31}$ Idem, ibidem, p. 71-72

${ }^{32}$ Idem, ibidem, p. 72

${ }^{33}$ Idem, ibidem, p. 73
} 
O controle da Administração por parte da sociedade, do Poder Judiciário e de outros entes que têm essa função fiscalizadora é facilitada pelo esquema processual, por envolver a colaboração dos sujeitos e o modo de atuação administrativa ${ }^{34}$.

E, por fim, verifica-se que o processo administrativo é meio de aplicação concreta dos princípios e regras a que está sujeita a Administração Pública.

Celso Antônio Bandeira de Mello ${ }^{35}$, acrescenta mais uma finalidade ao processo administrativo dizendo que este

revela-se de grande utilidade para complementar a garantia da defesa jurisdicional porquanto, em seu curso, aspectos de conveniência e oportunidade passíveis de serem levantados pelo interessado podem conduzir a Administração a comportamentos diversos dos que tomaria, em proveito do bom andamento da coisa pública e de quem os exibiu em seu interesse. [...] Tais aspectos não poderiam ser objeto de apreciação na via jurisdicional, que irá topar com o ato sem poder levar em conta senão a dimensão da legalidade.

A observação feita pelo doutrinador é extremamente pertinente ao processo administrativo revisor de ato administrativo inválido. A autoridade administrativa, diante de um ato administrativo inválido - seja por vício de mérito ou de legalidade - terá de tomar a decisão entre revogar, anular ou convalidar o ato e, para isso, como foi demonstrado, deverá adotar a solução que mais atenda ao interesse público, avaliando aspectos de conveniência e oportunidade. E, somente no âmbito do processo administrativo será possível discutir tais aspectos que dizem respeito ao mérito do ato.

\subsection{Fases do processo administrativo}

O processo administrativo desenvolve-se através de fases, cada qual composta de um conjunto de atos conexos entre si, preparatórios da decisão final.

\footnotetext{
${ }^{34}$ Idem, Ibidem, p.73

${ }^{35}$ MELLO, Celso Antonio Bandeira. Curso de Direito Administrativo. 17. ed., São Paulo: Malheiros, 2004, p. 457
} 
Passaremos a elencar de forma específica as fases do processo administrativo revisor de ato administrativo inválido.

\subsubsection{Fase de instauração}

Representa o início do processo administrativo. Em se tratando de processo administrativo revisor de ato administrativo inválido, ela pode ser deflagrada por iniciativa do particular ou da própria Administração Pública.

O particular tem legitimidade para solicitar a instauração de processo administrativo quando tiver interesse direto na anulação de ato administrativo que restringiu sua esfera de direitos, ou então quando tomar conhecimento de qualquer ilegalidade ocorrida no âmbito da Administração Pública mesmo que tal ilegalidade não tenha lhe causado qualquer lesão.

Conforme observamos em capítulos anteriores, a Administração Pública tem o dever de restaurar a legalidade. Assim, a instauração de processo administrativo para tal fim é obrigatório para a autoridade administrativa, sempre que houver suspeita de ilegalidade.

Iniciado o processo, seja por iniciativa do particular que denuncia vício do ato, seja de oficio, a autoridade administrativa responsável deverá instaurá-lo e dar andamento ao mesmo.

\subsubsection{Fase de instrução}

Esta talvez a fase mais importante do processo administrativo, pois será através dela que a autoridade administrativa responsável pela edição do ato final colherá todos os elementos necessários à formação da sua convicção. É necessária tanto para os casos em que a decisão final (anulação, revogação ou convalidação) resulte na restrição, como na ampliação da esfera jurídica dos interessados, uma vez que a Administração tem o dever de zelar pela correção da decisão.

É nesta fase instrutória que são concretizados os princípios do contraditório e da ampla defesa. 
Para que os interessados possam exercitar o contraditório e a ampla defesa, a Administração deve informa-los de sua intenção de rever o ato administrativo e as razões para tal, concedendo-lhes vista dos autos, bem como prazo para que se manifestem.

Nessa fase deverão ser ouvidos os que serão alcançados pelos efeitos do ato final, bem como produzidas todas as provas (pericias, exames, laudos técnicos, pareceres) necessárias à formação da convicção da autoridade responsável pela decisão final.

\subsubsection{Fase decisória}

É nesta terceira fase que a autoridade administrativa, depois de analisar todos os elementos constantes do processo, profere sua decisão.

Em se tratando de processo administrativo revisor de ato administrativo inválido, a autoridade poderá chegar a uma das seguintes conclusões: a) o ato não tem vício; b) o ato tem vício sanável; c) o ato tem vício insanável.

Concluindo pela inexistência de vício no ato, a decisão deve ser pela sua manutenção. Neste caso, embora a Administração suspeitasse da ilegalidade do ato, após o desenvolvimento do processo administrativo, a autoridade que o preside, verificando que o ato não se reveste de qualquer vício, deve mantê-lo. Verifica-se, mais uma vez, a importância da manifestação prévia do interessado, na defesa da legitimidade do ato pretensamente inválido.

Se a conclusão for pela existência de vício sanável, poderá a autoridade anulá-lo ou convalidá-lo. A decisão final depende de análise minuciosa das circunstâncias do caso concreto, com o sopesamento dos interessem em jogo.

Por fim, se a conclusão for pela existência de vício insanável, como regra geral deverá a autoridade anulá-lo. Poderá, no entanto, mantê-lo, em circunstâncias especiais, verificáveis no curso do processo, tendo em conta razões de segurança jurídica e de interesse público. Porque é possível, como já fico dito anteriormente, que a anulação cause maiores prejuízos ao interesse público. 
É nessa fase decisória que aparece, de forma mais nítida, a enorme importância dos princípios do contraditório e da ampla defesa. Porque eles permitem um aclaramento mais preciso dos fatos, condicionando a decisão da autoridade administrativa.

\subsubsection{Fase de comunicação}

Proferida a decisão, a Administração deve comunicá-la aos interessados. Esta comunicação é de extrema importância, pois caso seja desfavorável, o interessado poderá impugná-la administrativa ou judicialmente. Ainda que a decisão amplie a esfera de direitos do interessado direto, permanece a necessidade de comunicação, uma vez que poderá prejudicar terceiros e estes terão direito a apresentar recurso. É o caso, por exemplo, de processo administrativo instaurado - por provocação de um licitante - para anulação de procedimento licitatório, após declarado licitante vencedor. A conclusão pela legalidade do procedimento licitatório, será favorável ao vencedor da licitação, mas desfavorável aos demais.

\subsection{Necessidade de motivação}

Motivação é a demonstração da adequação da decisão às normas jurídicas e às provas. É o momento em que a autoridade administrativa justifica a decisão a que chegou, motivando-a. Considerando ser o motivo a condicionante que deflagra a atividade administrativa, sua explicitação pela motivação é necessária para fins de controle do ato praticado.

Celso Antônio Bandeira de Mello ${ }^{36}$ ressalta que a motivação deve conter além da indicação do dispositivo legal em que se baseou o ato, a descrição precisa das circunstancias fáticas e, em se tratando de competência discricionária, a relação lógica existente entre o fato e a providência adotada. E, prossegue explicando que

faltando a enunciação da regra jurídica proposta como aplicada, não se tem como saber se o ato é adequado, ou seja, se corresponde à competência utilizada; omitindo-se a enunciação dos fatos e situações à vista dos quais se está procedendo de dado modo, não se terá como

${ }^{36}$ MELLO, Celso Antonio Bandeira de. Grandes temas de Direito Administrativo. $1^{\text {a }}$ ed., $2^{\text {a }}$ tiragem, São Paulo: Malheiros, 2010, p. 111 
controlar a própria existência material de um motivo para ele, e menos ainda seu ajustamento à hipótese normativa; carecendo de fundamentação esclarecedora do porquê se agiu da maneira tal ou qual, não haverá como reconhecer-se, nos casos de discrição, se houve, ou não, razão prestante para justificar o ato, pois, se ele era, deveras, confortado pelo sistema normativo.

Não há mais controvérsia acerca da necessidade de motivação de todos os atos administrativos, sejam vinculados ou discricionários. Admite-se, entretanto, apenas a indicação do dispositivo legal aplicável quando se tratar de atos administrativos vinculados baseados em fatos destituídos de qualquer complexidade, como ocorre, por exemplo, na aposentadoria compulsória pelo implemento da idade ${ }^{37}$.

Em regra, a motivação deverá ser prévia a prática do ato. Apenas, em casos excepcionais, admite-se o suprimento do vício de ausência de motivação, com a motivação ulterior. Isso porque, caso se admita a motivação posterior, como poderá o administrado insurgir-se contra atos ilegais, desconhecendo as razões que justificaram a sua prática? Seria deslealdade por parte da Administração ocultar os motivos que poderiam ter sido refutados oportunamente e possivelmente alterado a decisão final, e exibi-los ou inventá-los ante a necessidade de justificar o ato frente à Justiça ${ }^{38}$.

O dever de motivar no processo administrativo revisor de ato administrativo inválido aplica-se tanto nos casos em que o resultado ocasione ampliação da esfera jurídica do administrado quanto naqueles que resultem em sua restrição.

Nas hipóteses de ampliação da esfera jurídica do administrado, a motivação, em especial a do ato final, objetiva resguardar a Administração de eventuais questionamentos da sociedade, demonstrando que sua atuação não se descurou do interesse público, deixando com que predominasse sobre este o interesse do particular.

De outro lado, quando o ato final resultar em prejuízo para o administrado, será por meio da motivação que este poderá se insurgir contra o ato revisor, seja no âmbito administrativo ou judicial.

\footnotetext{
${ }^{37}$ SUNDFELD, Carlos Ari. "Motivação do ato administrativo como garantia dos administrados". Revista de Direito Público, vol. 75, p. 118-127. São Paulo, jul. set.1995, p. 122

${ }^{38}$ SUNDFELD, Carlos Ari. Op. cit., p. 125
} 
É bom lembrar, nesse sentido, que a Lei 9.784/1999, ao se referir aos atos administrativos que devem ser motivados, reporta-se expressamente àqueles que "importem anulação, revogação, suspensão ou convalidação de ato administrativo" reforçando a ideia da necessidade de motivação tanto nos atos ampliativos como restritivos da esfera jurídica dos administrados, uma vez que dispõe de forma genérica não fazendo qualquer distinção entre os resultados dos atos revisores.

\subsection{Importância do processo administrativo na revisão de atos} administrativos inválidos

De todo o exposto, não resta dúvida quanto à necessidade de instauração de processo administrativo prévio à revisão de ato administrativo ilegal.

Os fundamentos para tal proceder são diversos. A Constituição Federal declara de forma expressa referida exigência (art. $5^{\circ}$, LIV e LV), conforme já comentamos. Da mesma forma a legislação infra-constitucional.

A Lei 8.666/93, no art. $49, \S 3^{\circ}$, determina que "no caso de desfazimento do processo licitatório, fica assegurado o contraditório e a ampla defesa”, objetivando que todos os licitantes possam se manifestar sobre a legalidade do certame - antes de seu desfazimento - o que somente poderá ocorrer no âmbito do processo administrativo.

A Lei 9.784/99, igualmente prevê a obrigatoriedade da observância do contraditório na Administração Pública Federal (art. $2^{\circ}$ ).

Em reiterados casos, nossos Tribunais têm reforçado tal entendimento, conforme podemos verificar, a título de exemplo nos seguintes julgados, cujas ementas transcrevemos:

MANDADO DE SEGURANÇA. NULIDADE DE ATO ADMINISTRATIVO PELA PRÓPRIA ADMINISTRAÇÃO. ILEGALIDADE RECONHECIDA. VIOLAÇÃO AOS PRINCÍPIOS DA MORALIDADE E DA IMPESSOALIDADE. APLICABILIDADE DAS SÚMULAS 346 E 473 DO STF. Na aplicação das Súmulas 346 e 473 do STF, tanto a Suprema Corte, quando este STJ, têm adotado com cautela, a orientação jurisprudencial inserida nos seus enunciados, firmando entendimento no sentido de que o Poder de a Administração 
Pública anular ou revogar os seus próprios atos não é tão absoluto, como às vezes se supõe, eis que, em determinadas hipóteses, hão de ser inevitavelmente observados os princípios constitucionais da ampla defesa e do contraditório. Isso para que não se venha a fomentar a prática de ato arbitrário ou a permitir o desfazimento de situações regularmente constituídas, sem a observância do devido processo legal ou de processo administrativo, quando cabível. Provimento do recurso ordinário ${ }^{39}$.

\begin{abstract}
ATO ADMINISTRATIVO - REPERCUSSÕES - PRESUNÇÃO DE LEGITIMIDADE - SITUAÇÃO CONSTITUIDA - INTERESSES CONTRAPOSTOS - ANULAÇÃO - CONTRADITORIO. Tratando-se da anulação de ato administrativo cuja formalização haja repercutido no campo de interesses individuais, a anulação não prescinde da observância do contraditório, ou seja, da instauração de processo administrativo que enseje a audição daqueles que terão modificada situação já alcançada. Presunção de legitimidade do ato administrativo praticado, que não pode ser afastada unilateralmente, porque e comum a Administração e ao $\operatorname{particular}^{40}$.
\end{abstract}

O processo administrativo é meio de garantir a efetividade do princípio do contraditório. Assim, sempre que Administração Pública se deparar com a necessidade de extinguir ato administrativo - ou seus efeitos - que tenha interferido na esfera de direitos de particulares, seja restringindo-os ou ampliando-os, a instauração de processo administrativo é obrigatória.

Por meio deste processo, o particular terá oportunidade de expor suas considerações defendendo a legalidade do ato que se pretende extinguir, ou a possibilidade de convalidá-lo em relação a atos ampliativos de sua esfera de direitos, ou caso estes tenham provocado restrição de direitos, poderá aduzir fundamentos para sua anulação.

No entanto, não se está a dizer que a única função do processo administrativo é garantir os direitos dos administrados. Não são somente os interesses particulares contemplados pelo processo administrativo. A Administração Pública, enquanto curadora dos interesses públicos, terá condições de produzir decisões mais justas

${ }^{39}$ STJ, RMS 10673-RJ, Rel. Min., Francisco Falcão, primeira Turma, DJ: 23/05/2000

${ }^{40}$ STF, RE 158.543-RS, Rel. Min. Marco Aurélio, segunda Turma, DJ: 30/08/1994 
e coerentes com o interesse da coletividade, uma vez que terá oportunidade de enriquecer sua decisão com uma visão ampla e detalhada dos fatos, que somente será possível com a colaboração dos interessados durante o processo administrativo. 


\section{CONCLUSÕES}

1. O ato administrativo, espécie de ato jurídico, é toda declaração de vontade proferida pela Administração Pública, ou de quem a represente que, agindo nesta qualidade - com supremacia de poder, sujeita ao regime jurídico administrativo -, tem por fim produzir efeitos jurídicos de acordo com o interesse público. É o instrumento utilizado pelo Estado para se desincumbir da função administrativa, nos termos determinados pelo ordenamento jurídico.

2. O ato administrativo é formado por cinco elementos: a) sujeito, b) motivo, c) forma, d) objeto, e) finalidade. Tais elementos são condicionadores de sua existência, de forma que a ausência de algum deles torna o ato inexistente juridicamente.

3. A fim de concretizar as finalidades prescritas pelo ordenamento jurídico, o ato administrativo é dotado de algumas características, denominadas de atributos. São elas: a) presunção de legitimidade, b) imperatividade e c) autoexecutoriedade. São estes atributos que conferem eficácia ao ato administrativo.

4. Por força do princípio da legalidade, toda atuação administrativa deve observar o que está prescrito no ordenamento jurídico. No entanto, nem sempre isso ocorre. Muitas vezes a Administração Pública pratica atos inválidos, por causa de vícios que podem incidir nos elementos do ato administrativo. $\mathrm{O}$ ato administrativo pode ser inválido desde sua origem, quando o agente que o pratica não tem competência legal ou não observa formalidades essenciais exigidas em lei, ou ainda porque se desvia da finalidade prevista. Isso também pode ocorrer quando o agente se baseia em motivo inexistente, ou não coerente com a espécie de ato praticado. Por último, o ato pode se tornar inválido pela ocorrência de fato superveniente, de forma a não mais atender ao interesse público.

5. A teoria civilista das nulidades, que classifica os atos jurídicos em nulos, anuláveis e inexistentes, não pode ser transposta para o Direito Administrativo, tendo em vista as diferenças substanciais existentes entre o ato jurídico administrativo e o ato jurídico privado. A principal delas consiste no fato de que o ato administrativo visa sempre atingir uma finalidade de interesse público, e o ato jurídico privado tem como finalidade atender a um interesse particular. Assim, o Direito Administrativo dela aproveita 
somente a nomenclatura, utilizando-se de critérios diversos quanto às diferenças entre os atos administrativos nulos e anuláveis.

6. No Direito Administrativo Brasileiro não há uma sistematização legal da teoria das nulidades, aplicável de maneira uniforme em todas as entidades da Federação, em razão da independência das mesmas em estabelecer sua própria legislação administrativa. Por este motivo, a doutrina tem procurado estabelecer os critérios diferenciadores entre atos nulos e anuláveis. Dentre os vários critérios apontados pela doutrina, entendemos que o da possibilidade de convalidação é o de maior utilidade para o aplicador do direito.

7. O princípio da legalidade acompanhou as transformações ocorridas na concepção de Estado. Atualmente, no Estado Democrático de Direito é visto como princípio da juridicidade, ou seja, determina a submissão da Administração Pública a todo ordenamento jurídico, desde a Constituição até os Regulamentos que a própria Administração Pública edita. Como consequência dessa evolução, a atuação administrativa busca fundamento diretamente na Constituição. Além disso, permite a possibilidade de, diante de um ato administrativo viciado e inconvalidável, tolerar-se sua permanência no mundo jurídico em razão do princípio constitucional da segurança jurídica e proteção à boa-fé. Diante da ocorrência, num caso concreto, de uma tensão entre dois princípios constitucionais - legalidade, que exigiria a anulação do ato, e segurança jurídica, que exigiria a sua manutenção - é esse último que deve prevalecer, porque o princípio da segurança jurídica inclui-se no âmbito do princípio da legalidade, em seu sentido amplo.

8. O principio da segurança jurídica é um dos pressupostos do Estado de Direito e amplamente aplicado nas relações entre o Estado e o particular. No âmbito da Administração Pública, justifica a manutenção de atos administrativos inválidos, bem como é fundamento para o instituto da prescrição e da decadência do poder de a Administração pública anular seus próprios atos.

9. Diante de um ato administrativo inválido, a Administração Pública, em razão de sua submissão ao princípio da legalidade, tem obrigação de restaurar a legalidade. Isso pode ser feito tanto pela retirada do ato administrativo inválido, por meio da anulação ou revogação, como pela manutenção do ato, através da convalidação, conversão ou ratificação. Outra possibilidade é a manutenção do ato inválido sem alteração, quando não for possível a convalidação e sua anulação ocasionar um prejuízo maior ao interesse público, quando as relações jurídicas dele originadas estiverem estabilizadas no tempo. 
10. A revogação é a extinção de um ato administrativo ou de seus efeitos, em razão deste não mais atender ao interesse público. Pode ser parcial ou total, expressa ou tácita. Tem natureza jurídica de ato desconstitutivo e produz efeitos para o futuro. Isso porque o ato sendo válido até a ocorrência do fato que o tornou contrário ao interesse público, válidos também eram os efeitos por ele produzidos.

11. Os atos administrativos abstratos podem ser revogados a qualquer momento, pois não tratam de relações jurídicas individualizadas. Ao contrário, os atos administrativos concretos, por disporem sobre situações específicas, podem gerar situações irrevogáveis. Porém, esta irrevogabilidade não é absoluta, pois razões de interesse público podem determinar a necessidade de revogação, compensando-se a lesão ao direito do particular por meio de pagamento de indenização.

12. A anulação é a retirada de um ato administrativo, ou de seus efeitos, em decorrência de uma ilegalidade praticada no momento de sua edição. Em se tratando de atos abstratos, elimina-se o próprio ato inválido, impedindo-o de continuar produzindo efeitos, bem como afastando os efeitos já produzidos. Caso a anulação incida sobre atos concretos, extinguem-se somente as relações jurídicas por ele produzidas, pois esta espécie de atos se exaure logo após a produção de seus efeitos. É ato declaratório, pois apenas declara uma situação de ilegalidade pré-existente. Declarada a ilegalidade é como se o ato nunca tivesse existido. Daí produzir efeitos "ex tunc".

13. A anulação do ato administrativo que amplia a esfera de direitos dos particulares de boa-fé, ou seja, que não concorreram para a prática de ilegalidade, encontra limites nos princípios da segurança jurídica, da proteção à confiança e interesse público. Assim, poderão ocorrer situações em que, ao analisar todas as circunstancias do caso concreto, o administrador perceba não ser possível a anulação e opte por outra forma de restauração da legalidade. No entanto, caso opte pela anulação, o particular deverá ser indenizado, porque assim o exige a presunção de legalidade que cerca o ato administrativo, levando-o a confiar na lisura do provimento administrativo.

14. Convalidação é a manutenção dos efeitos do ato inválido, decorrente da produção de outro ato administrativo, semelhante ao primeiro, porém sem vício, que absorve como seus os efeitos produzidos pelo ato inválido. Desta forma, para que possa haver convalidação é necessário que o ato possa ser reproduzido sem vício e, ainda, que haja possibilidade de retroação para herdar os efeitos do ato inválido. 
15. A impugnação do ato administrativo inválido pelo particular não constitui óbice à convalidação. $\mathrm{O}$ interesse público, que se sobrepõe ao interesse do particular em ver o ato anulado, é atendido pela restauração da legalidade, seja pela anulação, seja pela convalidação. E, ambas, podem ocasionar prejuízos ao particular, o que pode ser resolvido com a indenização, que é a forma de equilibrar a prevalência do interesse público sobre o privado.

16. O decurso do tempo pode constituir óbice à anulação do ato administrativo, mas não à sua convalidação, em especial quando se tratar de ato inválido ampliativo da esfera de direitos do particular.

17. A obrigatoriedade da Administração Pública, diante de ato administrativo inválido, é de restaurar a legalidade. Não há, portanto, prevalência da convalidação sobre a anulação. Serão as circunstâncias concretamente consideradas que determinarão uma ou outra providencia.

18. A Administração Pública tem o poder de rever seus próprios atos, seja anulando-os, convalidando-os ou revogando-os. Porém, este poder encontra limites temporais, fundamentado no princípio da segurança jurídica que estabelece a necessidade de estabilização das relações jurídicas constituídas.

19. O prazo para que a Administração Pública exerça a autotutela é de natureza decadencial, porque atinge o próprio direito. Já o prazo para a Administração Pública pleitear a nulidade do ato perante o Poder Judiciário tem natureza prescricional. Esgotado o prazo decadencial para a Administração invalidar o próprio ato, pode ela valerse da ação judicial para buscar aquele efeito.

20. A prescritibilidade, ou a incidência de prazo decadencial, para a Administração Pública anular seus próprios atos é a regra. Portanto, a imprescritibilidade, prima facie, não pode ser presumida.

21. Ante a ausência de disposição legal expressa, o prazo decadencial para a Administração Pública anular seus atos inválidos, ampliativos da esfera de direito dos particulares que estejam de boa-fé, é de cinco anos, por analogia ao prazo previsto pela Lei 9.784/99.

22. A exceção à regra de prescritibilidade, além das hipóteses previstas expressamente no ordenamento jurídico, ocorre em relação à anulação de atos restritivos de direito dos particulares e a atos ampliativos de direito praticados com má-fé de seu 
beneficiário. Em ambas as hipóteses é o princípio da moralidade que determina tal providencia. Nestes casos, o decurso do tempo, somente agrava a lesão e a ilegalidade.

23. A Administração Pública pode pleitear, como visto, a anulação do ato administrativo perante o Poder Judiciário. Porém, isso só deve ocorrer após o decurso do prazo decadencial para a autotutela, em obediência ao princípio da eficiência administrativa.

24. A melhor interpretação do disposto no art. $37, \S 5^{\circ}$, da Constituição Federal, é aquela que sustenta a imprescritibilidade da ação de ressarcimento de danos causados ao Erário.

25. Considerando a legalidade em sentido amplo, é possível afirmar que a prescrição ou a decadência restauram a legalidade. Existindo disposição legal expressa acerca do prazo prescricional, o atendimento desta sobrepõe-se à circunstancia anterior de ilegalidade. E, inexistindo disposição expressa, a aplicação direta do princípio da segurança jurídica, abrangido pela legalidade, determina a impossibilidade de anulação do ato administrativo ilegal.

26. A revisão de ato administrativo ilegal, seja por meio da anulação, convalidação ou revogação, deve ser precedida de processo administrativo. A obrigatoriedade de instauração de processo administrativo encontra seu principal fundamento no art. $5^{\circ}$, LIV, da Constituição Federal, ao prever que "ninguém será privado da liberdade ou de seus bens sem o devido processo legal". Isso porque a alteração provocada pela revisão do ato administrativo pode causar lesão à esfera de direitos do particular.

27. A instauração do processo administrativo, com as garantias a ele inerentes - contraditório, ampla defesa e motivação - tanto protege o particular, na medida em que permite ao mesmo influir na decisão administrativa, seja defendendo a legalidade do ato que se pretende extinguir ou a sua possibilidade de convalidação, seja aduzindo fundamentos para sua extinção, como também atende ao interesse público, pois com a colaboração dos interessados a Administração Pública tem condições de proferir decisão mais justa e de acordo com os interesses da coletividade. 


\section{BIBLIOGRAFIA}

ALESSI, Renato. Instituiciones de Derecho Administrativo. Trad. Buenaventura Pellisé Prats. Tomo I. Barcelona: Bosh, 1970.

ALEXY, Robert. Teoria dos direitos fundamentais. Tradução de Virgílio Afonso da Silva. São Paulo: Malheiros, 2008.

AMARAL, Antônio Carlos Cintra do. Teoria do ato administrativo. Belo Horizonte: Fórum, 2008.

. Extinção do Ato Administrativo. São Paulo: RT, 1978.

ARAÚJO, Edmir Netto de. Curso de Direito Administrativo. 6. ed. São Paulo: Saraiva, 2014.

. Convalidação do Ato Administrativo. São Paulo: LTr, 1999.

- "Atos administrativos e recomposição da legalidade". In Revista de Direito Administrativo, Rio de Janeiro, n. 207, p. 163-201, jan/mar, 1997.

ARAGÃO, Alexandre Santos de; MARQUES NETO, Floriano de Azevedo. Direito Administrativo e seus novos paradigmas. Belo Horizonte: Fórum, 2008.

AVILA, Humberto. "Repensando o princípio da supremacia do interesse público sobre o particular”. Revista Trimestral de Direito Público. São Paulo, nº 24, p. 159-180, 1998.

BARROSO, Luis Roberto. "Prescrição administrativa. Autonomia do direito administrativo e inaplicabilidade da regra geral do código civil". Revista dos Tribunais. São Paulo, vol. 779, set. 2000, p.113-132.

BENVENUTI, Feliciano. "Funzione amministrativa, procedimento, processo". Rivista Trimestrale di Diritto Púbblico. Milano: Giufrée, Ano II, 1952, p. 118-145. 
BINENBOJM, Gustavo. "O sentido da vinculação administrativa à juridicidade no direito brasileiro”. In ARAGÃO, Alexandre Santos de; MARQUES NETO, Floriano de Azevedo. Direito Administrativo e seus novos paradigmas. Belo Horizonte: Fórum, 2008, p. 156204.

CAMMAROSANO, Márcio. "Decaimento e extinção dos atos administrativos". Revista de Direito Público, São Paulo, no 53-54, jan-jun.1980, p. 161-172.

CANOTILHO, José Joaquim Gomes. Direito Constitucional e Teoria da Constituição. $3^{\mathrm{a}}$ ed. Coimbra: Almedina, 1999.

CARLINI, Haydée Antunes. "Invalidade dos atos administrativos". Revista de Direito Público, São Paulo, vol. 34, abr-jun. 1975, p. 26-33.

CARNELUTTI, Francesco. Teoria Geral do Direito. Tradução de Antônio Carlos Ferreira. São Paulo: Lejus, 1999.

CARRIO, Genaro R. Princípios jurídicos y positivismo jurídico. Buenos Aires: Abeledo. Perrot, 1970.

CARVAlHO FILHO, José dos Santos. Manual de Direito Administrativo. 25. ed. São Paulo: Atlas, 2012.

CRETTELA JÚNIOR, José. Controle jurisdicional do ato administrativo. 3. ed. Rio de Janeiro: Forense, 2001. . Do ato administrativo. São Paulo: José Bushatsky, 1972.

DI PIETRO, Maria Sylvia Zanella, e RIBEIRO, Carlos Vinícius Alves. Supremacia do interesse público e outros temas relevantes do direito administrativo. São Paulo: Atlas, 2010.

DI PIETRO, Maria Sylvia Zanella. Direito Administrativo. 26. ed., São Paulo: Atlas, 2013 24. ed. São Paulo: Atlas, 2011. 
- "O princípio da proteção à confiança, da segurança jurídica e da boa-fé na anulação do ato administrativo". Fórum Administrativo-Direito Público - FA, Belo Horizonte, ano 9, n. 100, jun. 2009, p. 155-166.

. "Autotutela: poder de revisão dos atos pela Administração. In $B D A$ - Boletim de Direito Administrativo. abr. 1996.

DROMI, José Roberto. Instituciones de Derecho Administrativo. Buenos Aires: Editorial Astrea de R. Depalma, 1973.

FAGUNDES, Miguel Seabra. O controle dos atos administrativos pelo Poder Judiciário. 8. ed. Rio de Janeiro: Forense, 2010.

5. ed. Rio de Janeiro: Forense, 1979.

FERRAZ, Luciano. "Segurança jurídica positivada: interpretação, decadência e prescritibilidade”. Revista Eletrônica sobre a Reforma do Estado (RERE), Salvador, Instituto Brasileiro de Direito Público, n. 22, junho, julho, agosto, 2010. Disponível em: $<$ http://www.direitodoestado.com/revista/RERE-22-JUNHO-2010-LUCIANO-

FERRAZ.pdf > . Acesso em: 15 mar. 2013.

FERRAZ, Sergio. "Extinção dos atos administrativos". Revista de Direito Administrativo. Rio de Janeiro, vol. 231, jan. mar. 2003, p. 47-66.

FRANÇA, R. Limongi. A irretroatividade das leis e o direito adquirido. 3. ed. São Paulo: Revista dos Tribunais, 1982.

FRANCO SOBRINHO, Manoel de Oliveira. Atos Administrativos. São Paulo: Saraiva, 1980.

FREITAS, Juarez. O controle dos atos administrativos e os princípios fundamentais. 4. ed. São Paulo: Malheiros, 2009.

2. ed., São Paulo: Malheiros Editores, 1999. 
FREITAS, Márcia Bellini. "Convalidação de atos anuláveis em Direito Administrativo". Revista Jurídica. v.174, RS, abr. 1992, p. 5-7.

GASPARINI, Diógenes. Direito Administrativo. 14. ed, São Paulo: Saraiva, 2009.

GRAU, Eros Roberto. O Direito posto e o Direito pressuposto. São Paulo: Malheiros, 2005 .

GUALAZZI, Eduardo Lobo Botelho. Ato administrativo inexistente. São Paulo: Revista dos Tribunais, 1980.

. "Ato administrativo inexistente". Revista Forense. Rio de Janeiro, vol. 257, jan. mar. 1977, p. 407-409.

HORBACH, Carlos Bastide. Teoria das nulidades do ato administrativo. São Paulo: Revista dos Tribunais, 2007.

JUSTEN FILHO, Marçal. Curso de Direito Administrativo. 4a . ed., São Paulo: Saraiva, 2009.

JUAREZ, Hugo A. Olguin. Extinción de los Actos Administrativo. Santiago: Editorial Jurídica de Chile, 1961.

LAZZARINI, Álvaro. "Da anulação de ato administrativo pela Administração Pública". $A$ Força Policial. São Paulo, vol. 63, jul. ago. set. 2009, p. 11-19.

LIMA, Rui Cirne. Princípios de Direito Administrativo. 5. ed. São Paulo: Revista dos Tribunais, 1982.

MACHADO, Yuri Restano. "O princípio da segurança jurídica e o nulo administrativo no direito brasileiro". Revista Forense. Rio de Janeiro, vol. 383, jan. fev. 2006, p. 541-550.

MARCHI, Eduardo C. Silveira. Guia de Metodologia Jurídica. $2^{\mathrm{a}}$ ed. São Paulo: Saraiva, 2009 
MEDAUAR, Odete. Atuais rumos do processo administrativo. São Paulo: Revista dos Tribunais, 2010.

. A processualidade no Direito Administrativo. $2^{\mathrm{a}}$ ed. São Paulo: Revista dos Tribunais, 2008.

. Direito Administrativo Moderno. 10ª ed. São Paulo: Revista dos Tribunais, 2006.

MEDEIROS, João Bosco. Redação científica. 11ª ed. São Paulo: Atlas, 2010.

MELlO, Celso Antonio Bandeira de. Grandes temas de Direito Administrativo. São Paulo: Malheiros, 2010.

. "Anulação de ato administrativo: devido processo legal e motivação". Revista de Direito Público. São Paulo, vol. 84, out. dez. 1987, p. 46-63.

. "Direito adquirido e Direito Administrativo". Revista Trimestral de Direito Público, São Paulo, vol. 44, 2003, p. 5-17.

- "Controle judicial dos limites da discricionariedade administrativa: Exame dos motivos ou pressupostos do ato - A noção de 'causa' como requisito da legalidade". Revista de Direito Público, vol. 31, set. out. 1974, p.33-39.

. "Discricionariedade administrativa e controle judicial". Revista de Direito Público. São Paulo, vol. 32, nov. dez. 1974, p.18-30.

. "Controle judicial dos atos administrativos". Revista de Direito Público. São Paulo, vol. 65, abr. jun. 1983, p. 1-15.

. Curso de Direito Administrativo. 17. ed., São Paulo: Malheiros, 2004.

MELlo, Oswaldo Aranha Bandeira de. Princípios Gerais de Direito Administrativo. $3^{\circ}$ ed. São Paulo: Malheiros, 2007. 
MENDES, Gilmar Ferreira; COELHO, Inocêncio Martires, BRANCO, Paulo Gustavo Gonet. Curso de Direito Constitucional. 4. ed. São Paulo: Saraiva, 2009.

MEIRELLES, Hely Lopes. Direito Administrativo Brasileiro. 27. ed. São Paulo: Malheiros, 2002.

MORAES, Alexandre de. "Princípio da Eficiência e Controle Jurisdicional dos Atos Administrativos Discricionários". Revista de Direito Administrativo. v. 243, set. dez. 2006, p.13-28.

MOREIRA, Egon Bockmann. Processo administrativo. Princípios Constitucionais e a Lei 9.784/1999. $4^{\text {a }}$ ed. São Paulo: Malheiros, 2010.

MOREIRA NETO, Diogo de Figueiredo. Curso de Direito Administrativo. Rio de Janeiro: Forense, 1994.

MOTTA, João Francisco da. Invalidação dos atos administrativos. Belo Horizonte: Del Rey, 2010.

OLIVEIRA, Regis Fernandes de. Ato administrativo. 5. ed. São Paulo: Revista dos Tribunais, 2007.

REALE, Miguel. Revogação e Anulamento do Ato administrativo. 2. ed. Rio de Janeiro: Forense, 1980.

SANTOS NETO, João Antunes dos. Da anulação ex officio do ato administrativo. Belo Horizonte: Fórum, 2004.

SCHIRATO, Vitor Rhein. "Limites à possibilidade de anulação dos atos administrativos". Boletim de Direito Administrativo, v.9, São Paulo, set. 2007, p. 1042-1058.

SILVA, Almiro do Couto e. "Princípios da legalidade da administração pública e da segurança jurídica no estado de direito contemporâneo". Revista de Direito Público. São Paulo, vol. 84, out. dez.1987 p. 46-63. 
SILVA, Almiro do Couto e. "O princípio da segurança jurídica (proteção à confiança) no direito público brasileiro e o direito da Administração Pública de anular seus próprios atos administrativos: o prazo decadencial do art. 54 da Lei do Processo Administrativo da União (Lei 9.784/99)". Revista Eletrônica de Direito do Estado, Salvador, Instituto de Direito Público da Bahia, n. 2, abr. mai. jun., 2005. Disponível em: $<$ http://www.direitodoestado.com.br>. Acesso em 12 de março de 2013.

SILVA, Clarissa Sampaio. Limites à invalidação dos atos administrativos. São Paulo: Max Limonad, 2001.

SILVA, José Afonso da. Curso de Direito Constitucional Positivo. 25a ed. São Paulo: Malheiros, 2005.

SIMÕES, Monica Martins Toscano. O processo administrativo e a invalidação de atos viciados. São Paulo: Malheiros, 2004.

STASSINOPOULOS, Michel. Traité des actes adminitratifs. Paris: Librairie Générale de Droit et de Jurisprudence, 1973.

STOCO, Rui. "Revisão dos atos administrativos após decurso do prazo de cinco anos: a questão da preclusão temporal”. Revista dos tribunais. v. 886, ago. 2009, p.41 a 53.

SUNDFELD, Carlos Ari. "Motivação do ato administrativo como garantia dos administrados". Revista de Direito Público, vol. 75. São Paulo, jul. set. 1995, p. 118-127.

SUNDFELD, Carlos Ari. Ato administrativo inválido. São Paulo: Revista dos Tribunais, 1990.

SUNDFELD, Carlos Ari. "A importância do procedimento administrativo". Revista de Direito Público. São Paulo, vol. 84, out. dez. 1987, p. 65-74

TÁCITO, Caio. Temas de Direito Público (Estudos e Pareceres). $1^{\circ}$ vol. Rio de Janeiro: Renovar, 1997. 
- “Ética e moralidade dos atos administrativos”. In: TELLES, Antonio Augusto Queiroz; ARAÚJO, Edmir Netto de. Direito Administrativo na década de 90. São Paulo: Revista dos Tribunais, 1997, p. 28-40.

VIRGA, Pietro. Il Provvedimento amministrativo. 4ª ed. Milano: A. Giuffré Editore, 1972.

VITRAL, Valder. Vocabulário Jurídico. 4ª ed., Rio de Janeiro: Forense,1986.

ZANCANER, Weida. Da convalidação e da invalidação dos atos administrativos. $3^{\mathrm{a}}$ ed. São Paulo: Malheiros, 2008.

. "Convalidação, Invalidação e Revogação do ato administrativo". In: MELLO, Celso Antonio Bandeira de (Coord.). Direito Administrativo na Constituição de 1988. São Paulo: Revista dos Tribunais, 1991. 